\title{
Pre-and Post-Reservoir Ground-Water Conditions and Assessment of Artificial Recharge at Sand Hollow, Washington County, Utah, 1995-2005
}

Scientific Investigations Report 2005-5185

Prepared in cooperation with the

Washington County Water Conservancy District, Bureau of Reclamation, and the University of Utah Department of Geology and Geophysics 



\section{Pre- and Post-Reservoir Ground-Water Conditions and Assessment of Artificial Recharge at Sand Hollow, Washington County, Utah, 1995-2005}

By V.M. Heilweil, D.D. Susong, P.M. Gardner, and D.E. Watt

U.S. GEOLOGICAL SURVEY

Scientific Investigations Report 2005-5185

Prepared in cooperation with the

WASHINGTON COUNTY WATER CONSERVANCY DISTRICT, BUREAU OF RECLAMATION, and the

UNIVERSITY OF UTAH DEPARTMENT OF GEOLOGY AND GEOPHYSICS

Salt Lake City, Utah 


\section{U.S. DEPARTMENT OF THE INTERIOR}

GALE A. NORTON, Secretary

\section{U.S. GEOLOGICAL SURVEY}

P. Patrick Leahy, Acting Director

Any use of trade, product, or firm names in this publication is for descriptive purposes only and does not imply endorsement by the U.S. Government.

For additional information write to:

District Chief

U.S. Geological Survey 2329 West Orton Circle

Salt Lake City, Utah 84119

http://ut.water.usgs.gov
For more information about the USGS and its products:

Telephone: 1-888-ASK-USGS

World Wide Web: http://www.usgs.gov/ 


\section{CONTENTS}

Abstract

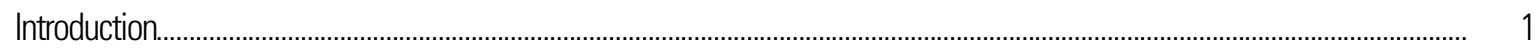

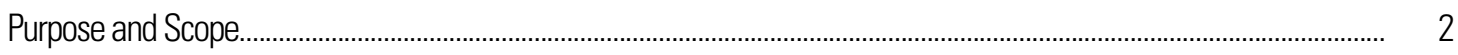

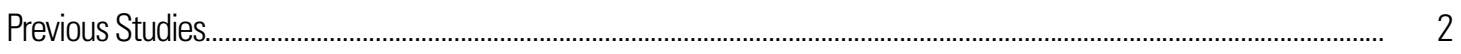

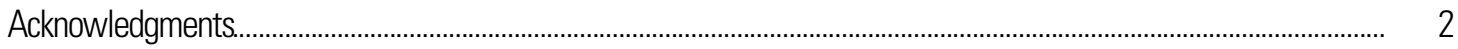

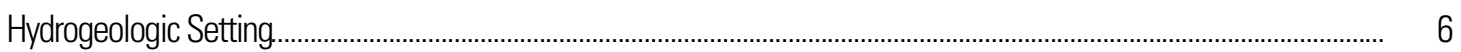

Methods

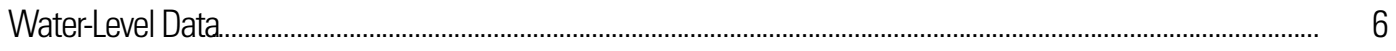

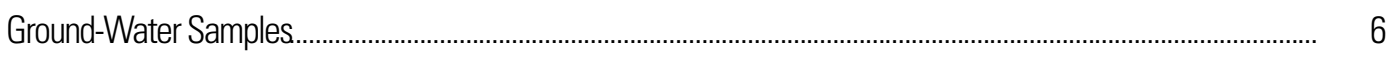

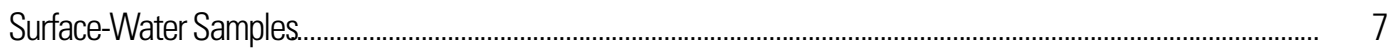

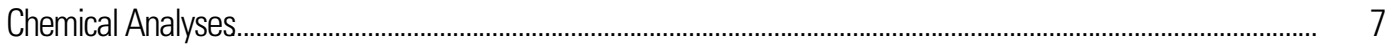

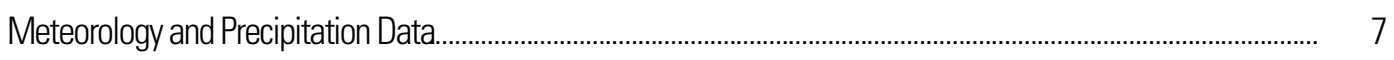

Temperature of Reservoir Water........................................................................................................................... 8

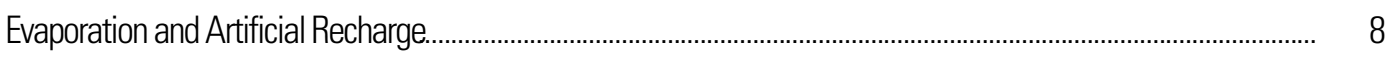

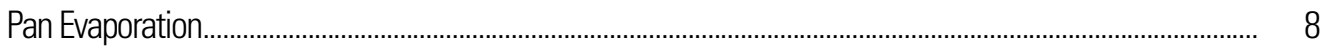

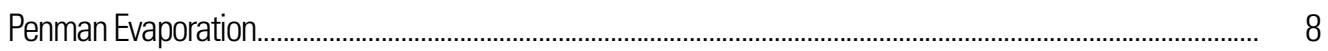

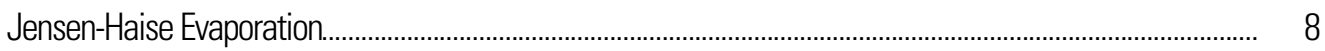

Turbulent-Transfer Evaporation....................................................................................................................... 9

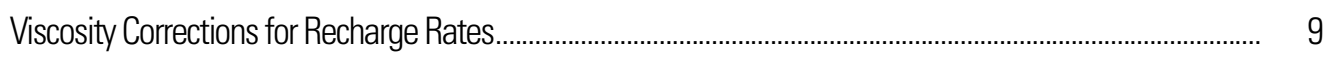

Pre- and Post- Reservoir Ground-Water Conditions........................................................................................................................... 10

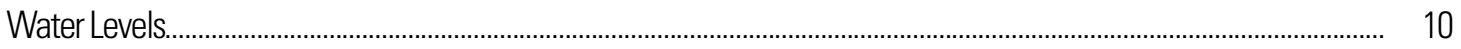

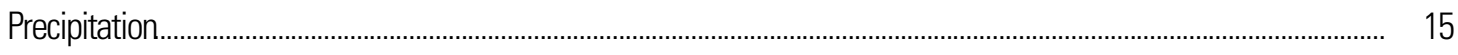

Pre-Reservoir Ground-Water Quality.................................................................................................................................... 18

Apparent Age of Pre-Reservoir Ground Water................................................................................................................. 20

Virgin River and Sand Hollow Reservoir Surface-Water Quality................................................................................... 21

Flushing of Naturally Accumulated Vadose-Zone Salts............................................................................................... 22

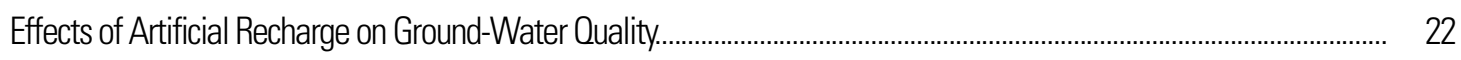

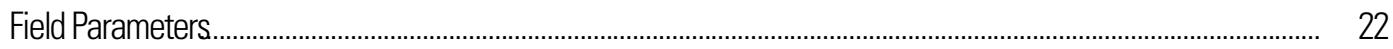

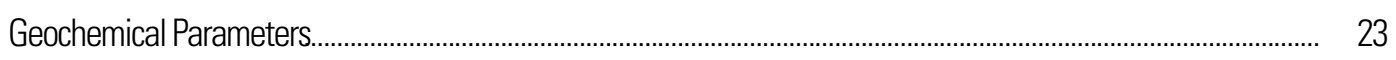

Assessment of Artificial Recharge...................................................................................................................................... 25

Comparison of Evaporation Rates................................................................................................................................... 25

Artificial Recharge Estimates...................................................................................................................................... 30

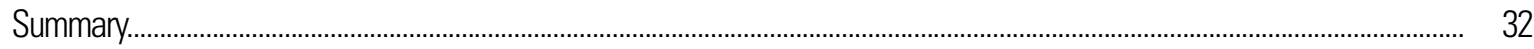

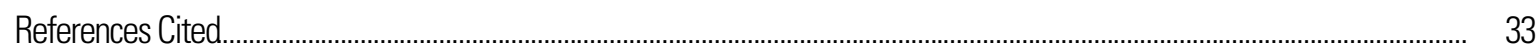




\section{FIGURES}

Figure 1. Location of Sand Hollow study area, Washington County, Utah...................................................... 3

Figure 2. Numbering system used for hydrologic-data sites in Utah ..................................................................... 4

Figure 3. Location of wells, borehole-core collection sites, and weather station in Sand Hollow, Utah....................... 5

Figure 4. Water level in selected wells in Sand Hollow, Utah, 1995-2005 ........................................................... 11

Figure 5. Potentiometric surface of the Navajo aquifer prior to completion of the reservoir, Sand Hollow, Utah ........... 12

Figure 6. Relation between water level in selected wells and reservoir altitude, Sand Hollow, Utah, 2000-05............. 13

Figure 7. Potentiometric surface of the Navajo aquifer in 2004, after completion of the reservoir and prior to pumping of production wells, Sand Hollow, Utah .............................................................................. 14

Figure 8. Annual precipitation from 1893-2004 at St. George, Utah, and from 1998-2004 at Sand Hollow, Utah. .......... 16

Figure 9. Monthly precipitation at Sand Hollow, Utah, 1998-2004.................................................................. 16

Figure 10. Relation between $\delta^{2} \mathrm{H}$ and $\delta^{18} 0$ values in precipitation, ground-, and surface-water samples in and near Sand Hollow, Utah

Figure 11. Major-ion chemistry of surface water, ground water, and ephemeral wash storm runoff in and near Sand Hollow, Utah

Figure 12. Relation between chloride-to-bromide ratio and chloride concentration for ground water and

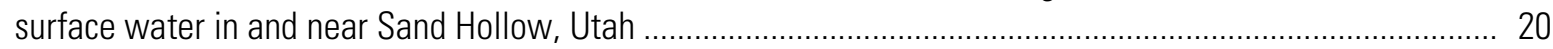

Figure 13. Specific conductance at shallow observation wells near Sand Hollow Reservoir, Utah, 2001-05 .................. 23

Figure 14. Relation between total dissolved-gas pressure in ground water and reservoir altitude, Sand Hollow, Utah, 2001-05

Figure 15. Relation between dissolved arsenic concentration in the North Dam 3A well and water level in the nearby WD 1 well, Sand Hollow, Utah, 2002-05

Figure 16. Daily evaporation rate calculated with the Jensen-Haise method for Sand Hollow Reservoir,

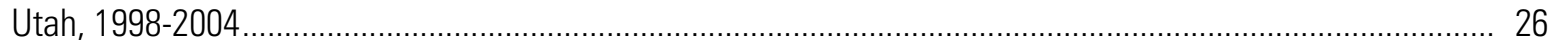

Figure 17. Average hourly water temperature at various depths in Sand Hollow Reservoir, Utah, 2003-04.................. 27

Figure 18. Daily evaporation calculated with the turbulent-transfer method for Sand Hollow Reservoir,

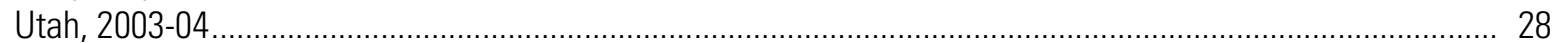

Figure 19. Comparison of average annual estimated evaporation rates for Sand Hollow Reservoir, Utah..................... 29

Figure 20. Monthly estimated evaporation, ground-water recharge, and reservoir altitude, Sand Hollow Reservoir, Utah, 2002-04

Figure 21. Monthly artificial recharge rate, viscosity-corrected hydraulic conductivity, and reservoir altitude, Sand Hollow Reservoir, Utah, 2002-04 


\section{TABLES}

Table 1. Records of selected wells and boreholes in Sand Hollow, Utah ......................................................... 36

Table 2. Water levels in selected wells in Sand Hollow, Utah ....................................................................... 40

Table 3. Selected physical properties and major and minor chemical constituents in ground- and surface-water samples collected from selected sites in Sand Hollow and the Virgin River near Virgin, Utah......

Table 4. Isotopic and chlorofluorocarbon concentrations of ground- and surface-water samples collected

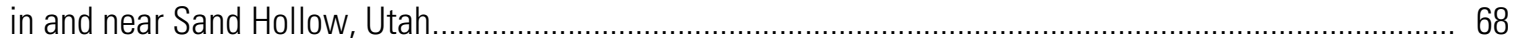

Table 5. Age and apparent recharge year of ground water in Sand Hollow, Utah ............................................ 72

Table 6. Average monthly and annual pan evaporation rates from St. George, Utah, and calculated evaporation rates with Jensen-Haise and turbulent-transfer methods using climate data collected at Sand Hollow, Utah, and calculated Penman evaporation rates using St. George climate data......

Table 7. Reservoir data and estimated evaporation and ground-water recharge at Sand Hollow, Utah, 2002-04 


\section{CONVERSION FACTORS, DATUMS, AND ABBREVIATED WATER-QUALITY UNITS}

\begin{tabular}{|c|c|c|}
\hline Multiply & By & To obtain \\
\hline \multicolumn{3}{|c|}{ Length } \\
\hline inch (in.) & 2.54 & centimeter $(\mathrm{cm})$ \\
\hline inch (in.) & 25.4 & millimeter (mm) \\
\hline foot $(\mathrm{ft})$ & 0.3048 & meter $(\mathrm{m})$ \\
\hline mile (mi) & 1.609 & kilometer (km) \\
\hline \multicolumn{3}{|c|}{ Area } \\
\hline acre & 4,047 & square meter $\left(\mathrm{m}^{2}\right)$ \\
\hline acre & 0.4047 & hectare (ha) \\
\hline acre & 0.4047 & square hectometer $\left(\mathrm{hm}^{2}\right)$ \\
\hline acre & 0.004047 & square kilometer $\left(\mathrm{k}^{2}\right)$ \\
\hline square mile $\left(\mathrm{mi}^{2}\right)$ & 259.0 & hectare (ha) \\
\hline square mile $\left(\mathrm{mi}^{2}\right)$ & 2.59 & square kilometer $\left(\mathrm{k}^{2}\right)$ \\
\hline \multicolumn{3}{|c|}{ Volume } \\
\hline acre-foot (acre-ft) & 1,233 & cubic meter $\left(\mathrm{m}^{3}\right)$ \\
\hline acre-foot (acre-ft) & 0.001233 & cubic hectometer $\left(\mathrm{hm}^{3}\right)$ \\
\hline cubic inch $\left(\mathrm{in}^{3}\right)$ & 16 & milliliter (ml) \\
\hline \multicolumn{3}{|c|}{ Flow rate } \\
\hline inch per day (in/d) & 2.54 & centimeters per day $(\mathrm{cm} / \mathrm{d})$ \\
\hline \multicolumn{3}{|c|}{ Hydraulic conductivity } \\
\hline foot per day $(\mathrm{ft} / \mathrm{d})$ & 0.3048 & meter per day $(\mathrm{m} / \mathrm{d})$ \\
\hline \multicolumn{3}{|c|}{ Hydraulic gradient } \\
\hline foot per foot $(\mathrm{ft} / \mathrm{ft})$ & 1 & meter per meter $(\mathrm{m} / \mathrm{m})$ \\
\hline foot per mile ( $\mathrm{ft} / \mathrm{mi})$ & 0.1894 & meter per kilometer $(\mathrm{m} / \mathrm{k})$ \\
\hline \multicolumn{3}{|c|}{ Weight } \\
\hline ton & $1,016.05$ & kilogram $(\mathrm{k})$ \\
\hline \multicolumn{3}{|c|}{ Dynamic viscosity } \\
\hline pounds per foot-second (lb/ft-sec) & 1,488 & centipoise \\
\hline
\end{tabular}

Temperature in degrees Celsius $\left({ }^{\circ} \mathrm{C}\right)$ may be converted to degrees Fahrenheit $\left({ }^{\circ} \mathrm{F}\right)$ as follows:

$$
{ }^{\circ} \mathrm{F}=\left(1.8 \times{ }^{\circ} \mathrm{C}\right)+32 .
$$

Vertical coordinate information is referenced to the North American Vertical Datum of 1988 (NAVD 88); horizontal coordinate information is referenced to the North American Datum of 1983 (NAD 83).

Specific conductance is reported in microsiemens per centimeter at 25 degrees Celsius $(\mu \mathrm{S} / \mathrm{cm})$.

Chemical concentration and water temperature are reported only in International System (SI) units. Chemical concentration in water is reported either in milligrams per liter $(\mathrm{mg} / \mathrm{L})$ or micrograms per liter $(\mu \mathrm{g} / \mathrm{L})$. Chemical concentration in rock is reported as parts per million (ppm). Atmospheric depo- 
sition of solutes is reported as milligrams per square inch $\left(\mathrm{mg} / \mathrm{in}^{2}\right)$ and milligrams per square centimeter $\left(\mathrm{mg} / \mathrm{cm}^{2}\right)$. The chlorofluorocarbon concentration in water is reported in picomoles per kilogram (pmole $/ \mathrm{kg}$ ). These units express the solute weight per unit volume (liter) or unit mass (kilogram) of water. A liter of water is assumed to weigh 1 kilogram. The numerical value in milligrams per liter is about the same as for concentrations in parts per million. One thousand micrograms per liter is equivalent to 1 milligram per liter, one million picomoles per kilogram is equivalent to 1 mole per liter, and one million parts per trillion is equivalent to 1 part per million. A mole of substance is its atomic or formula weight in grams. Concentration in moles per liter can be determined from milligrams per liter by dividing by the atomic or formula weight of the constituent, in milligrams. Stable isotope concentration is reported as per mil, which is equivalent to parts per thousand.

Tritium units (TU) are used to report tritium concentration. One TU equals tritium concentration in picoCuries per liter divided by 3.22 . 


\title{
Pre- and Post-Reservoir Ground-Water Conditions and Assessment of Artificial Recharge at Sand Hollow, Washington County, Utah, 1995-2005
}

\author{
By Victor M. Heilweil, David D. Susong, Philip M. Gardner, and Dennis E. Watt
}

\section{ABSTRACT}

Sand Hollow, Utah, is the site of a surface-water reservoir completed in March 2002, which is being operated by the Washington County Water Conservancy District. The reservoir is an off-channel facility receiving water from the Virgin River, diverted near the town of Virgin, Utah. It is being operated conjunctively, providing both surface-water storage and artificial recharge to the underlying Navajo aquifer. The U.S. Geological Survey and the Bureau of Reclamation conducted a study to document baseline ground-water conditions at Sand Hollow prior to the operation of the reservoir and to evaluate changes in ground-water conditions caused by the reservoir.

Pre-reservoir age dating using tritium/helium, chlorofluorocarbons, and carbon-14 shows that shallow ground water in the Navajo Sandstone in some highinfilration areas of Sand Hollow entered the aquifer from 2 to 25 years before sample collection. Ground water in low-infiltration areas and deeper within the aquifer may have entered the aquifer more than 8,000 years ago. Ground-water levels in the immediate vicinity of Sand Hollow Reservoir have risen by as much as 80 feet since initial filling began in March 2002. In 2005, ground water was moving laterally away from the reservoir in all directions, whereas the pre-reservoir direction of groundwater flow was predominantly toward the north.

Tracers, or attributes, of artificial recharge include higher specific conductance, higher dissolved-solids concentrations, higher chloride-to-bromide ratios, moredepleted stable isotopes $\left(\delta^{2} \mathrm{H}\right.$ and $\left.\delta^{18} \mathrm{O}\right)$, and higher totaldissolved gas pressures. These tracers have been detected at observation and production wells close to the reservoir. About 15,000 tons of naturally occurring salts that previously accumulated in the vadose zone beneath the reservoir are being flushed into the aquifer. Except for the shallowest parts of the aquifer, this is generally not affecting water quality, largely because of the large saturated thickness of the Navajo aquifer. Since the initial filling of Sand Hollow Reservoir, arsenic concentrations have risen to exceed U.S. Environmental Protection Agency standards in some shallow observation wells. These increases in arsenic concentration are likely caused by increasing $\mathrm{pH}$ associated with artificial recharge beneath the reservoir, rather than flushing of previously accumulated salts in the vadose zone. There has been no trend of increasing arsenic concentration in deeper production wells.

Estimated evaporation rates for Sand Hollow Reservoir, calculated by the Jensen-Haise method with data from the Sand Hollow weather station, range from about 55 to 61 inches per year and result in a total evaporative loss of about 6,000 acre-feet of water from March 2002 to September 2004. Rates of artificial recharge of ground water beneath Sand Hollow Reservoir have ranged from about 0.02 to 0.44 feet per day, with an average rate excluding the initial 3-month wetting period of about 0.06 feet per day. A total of about 28,000 acrefeet of recharge to the underlying Navajo aquifer occurred from March 2002 to September 2004.

\section{INTRODUCTION}

Ground water in fractured bedrock aquifers is increasingly being used to meet the demands of rapidly growing communities in the arid southwestern United States. The Navajo Sandstone is a regionally important bedrock aquifer. It is part of the Dakota-Glen Canyon aquifer system, consisting of permeable sedimentary formations ranging in age from Lower Jurassic to Upper Cretaceous, and is the principal source of ground water in the Colorado Plateau region (Robson and Banta, 1995). This aquifer system covers an area of more than 75,000 $\mathrm{mi}^{2}$ in Utah, Arizona, Colorado, and New Mexico. Many 


\section{Pre- and Post-Reservoir Ground-Water Conditions at Sand Hollow, Washington County, Utah, 1995-2005}

municipalities in this region, including most cities and towns in Washington County, Utah, derive the majority of their municipal water from the Navajo aquifer.

Washington County is in the northeastern corner of the Mojave Desert and is therefore the warmest, driest, and lowest-altitude part of Utah. Average annual precipitation at St. George, Utah, is about 8 in. per year (Western Region Climate Center, 2004). However, a recent 5-year drought has reduced this annual rainfall to about 5 in. during 1999-2003. Meanwhile, the population of Washington County has nearly doubled from 48,000 in 1990 to 90,000 in 2000 (U.S. Census Bureau, 1992, 2003) and is expected to increase to nearly 230,000 by 2020 (Boyle Engineering and Alpha Engineering, Washington County Water Conservancy District Purpose and Need Study, 84 p., written commun., 1995). The combination of low rainfall and rapid growth is driving the need to actively develop water resources, including ground water from the Navajo aquifer. To better manage this resource, Sand Hollow Reservoir was constructed in 2002 to provide both surface-water storage and artificial recharge to the underlying Navajo aquifer (fig. 1). This will use the storage within the previously unsaturated part of the Navajo Sandstone. The source of water for the reservoir is the Virgin River. Because of the large range of flow in the Virgin River caused by variable spring snowmelt runoff and monsoonal precipitation, the number of years required to fill Sand Hollow Reservoir is unknown. The maximum acreage and storage volume of the surface-water reservoir, when full, will be 1,300 acres and 50,000 acre-ft, respectively.

The numbering system used in Utah for hydrologic-data sites is illustrated in figure 2 . This system locates sites in the study area by township, range, and section. Corresponding map numbers for each of the sites are shown in figure 3 and are included for reference in all of the tables within the report.

\section{Purpose and Scope}

This report documents (1) baseline water-level and water-quality conditions in the Navajo aquifer of Sand Hollow prior to the construction of Sand Hollow Reservoir; (2) water-level and water-quality changes within the aquifer during the initial 3 years of operation of the reservoir; and (3) estimates of reservoir evaporation and ground-water recharge beneath Sand Hollow Reservoir. This is a cooperative study including the Washington County Water Conservancy District (WCWCD), the U.S. Geological Survey (USGS), the Bureau of Reclamation (BOR), and the University of
Utah Department of Geology and Geophysics. Supporting data presented in this report include well completion and water-level information, meteorology data, reservoir water-temperature profiles, and physical properties and chemical constituents for ground water and surface water. Chemical constituents include major and trace ions, nutrients, dissolved-gas concentrations, and stable and radioactive isotopes of hydrogen, oxygen, and carbon. Some of these chemical constituents collected prior to the completion of the surface-water reservoir are used for determining ages and residence times of ground water prior to artificial recharge.

\section{Previous Studies}

Geologic and previous hydrologic data for Sand Hollow are presented in Cordova (1978), Hurlow (1998), Wilkowske and others (1998), and Heilweil and others (2000). Vadose-zone physical and pore-water chemical properties of the Navajo Sandstone and the calculation of natural recharge rates by using environmental tracers is presented in Heilweil and others (in press). Vadose-zone solute accumulations in trenches and implications for the spatial variability of natural recharge at Sand Hollow are discussed in Heilweil and Solomon (2004). A field-scale infiltration pond artificial recharge experiment conducted prior to the construction of Sand Hollow Reservoir is described in Heilweil and others (2004). Additional hydrogeologic data are available in Heilweil (2003).

\section{Acknowledgments}

The authors would like to acknowledge the help of all those who cooperated with or contributed to this study. In particular, they thank Ron Thompson, Lloyd Jessup, and Chuck Carnie of the WCWCD for their help in facilitating the collection of the hydrologic data presented in this report. The authors are particularly grateful to Laura Wolfsberg and June Fabryka-Martin of the Los Alamos National Laboratory for providing chloride and bromide analyses with lower detection limits than were available through other laboratories. The authors also thank D. Kip Solomon and Alan Rigby of the University of Utah Dissolved Gas Service Center for the use of their field equipment and assistance in the collection and analysis of tritium and dissolved-gas samples. Appreciation also is extended to Craig Cook of 
Introduction 3

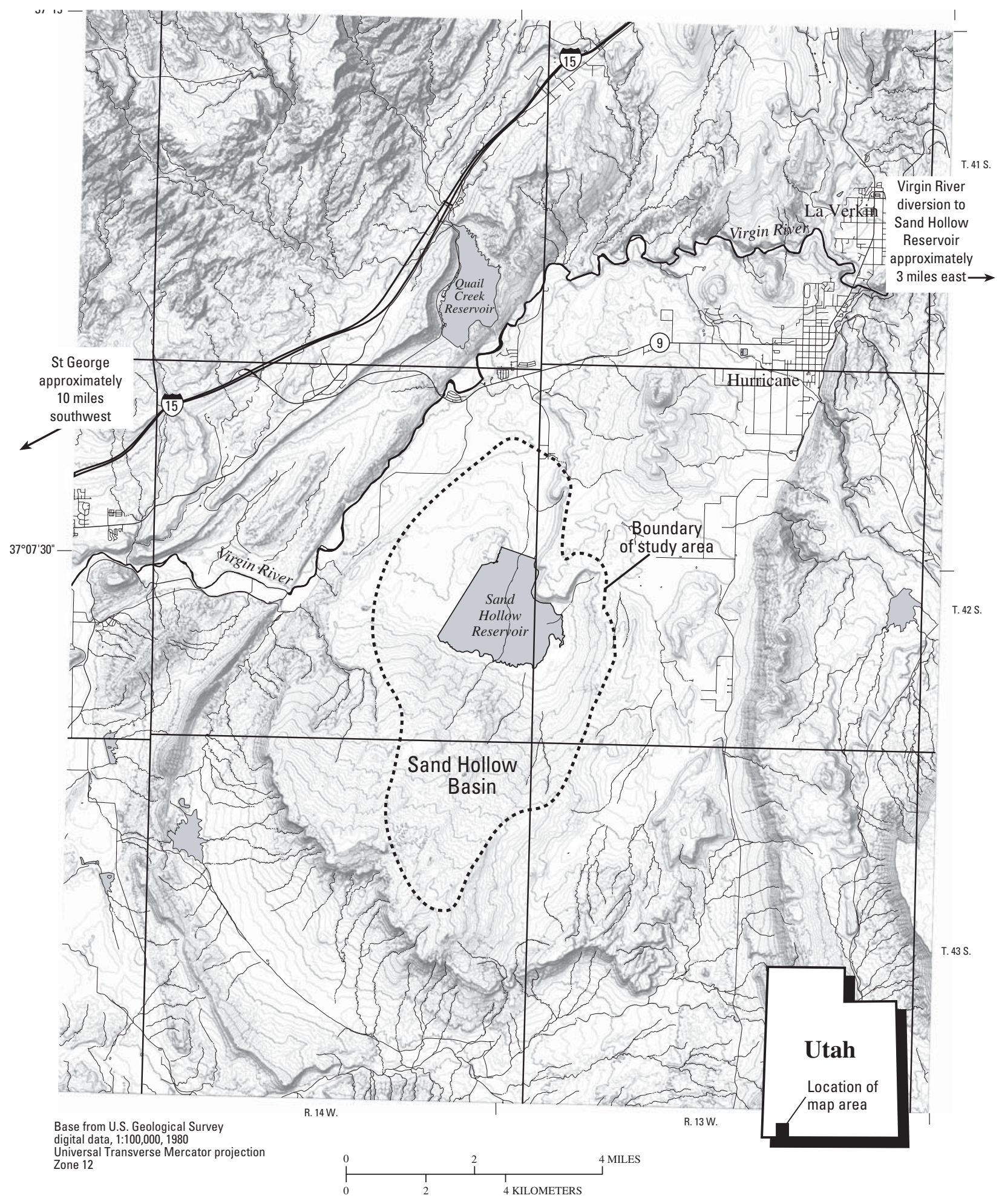

Figure 1. Location of Sand Hollow study area, Washington County, Utah. 
The system of numbering wells and springs in Utah is based on the cadastral land-survey system of the U.S. Government. The number, in addition to designating the well or spring, describes its position in the land net. The land-survey system divides the State into four quadrants separated by the Salt Lake Base Line and the Salt Lake Meridian. These quadrants are designated by the uppercase letters A, $\mathrm{B}, \mathrm{C}$, and D, indicating the northeast, northwest, southwest, and southeast quadrants, respectively. Numbers designating the township and range, in that order, follow the quadrant letter, and all three are enclosed in parentheses. The number after the parentheses indicates the section and is followed by three letters indicating the quarter section, the quarter-quarter section, and the quarter-quarter-quarter section-generally 10 acres for a regular section ${ }^{1}$. The lowercase letters a, b, c, and d indicate, respectively, the northeast, northwest, southwest, and southeast quarters of each subdivision. The number after the letters is the serial number of the well or spring within the 10-acre tract. When the serial number is not preceded by a letter, the number designates a well. When the serial number is preceded by an "S," the number designates a spring. A number having all three quarter designations but no serial number indicates a miscellaneous data site other than a well or spring, such as a location for a surface-water measurement site or tunnel portal. Thus, (C-40-17)24ddd-1 designates the first well constructed or visited in the southeast $1 / 4$ of the southeast $1 / 4$ of the southeast $1 / 4$ of section 24 , T. 40 S., R. 17 W.

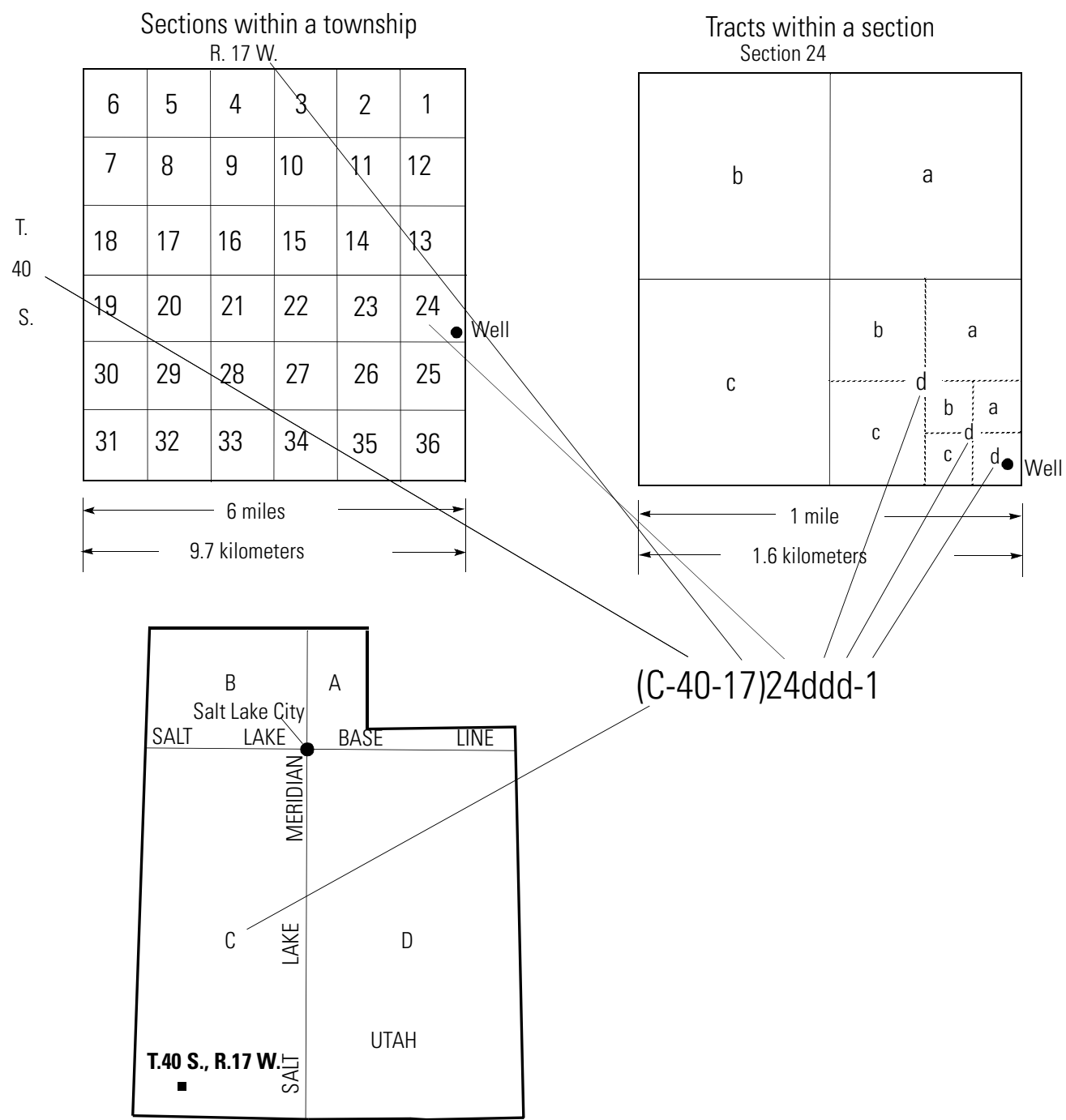

\footnotetext{
${ }^{1}$ Although the basic land unit, the section, is theoretically 1 square mile, many sections are irregular in size and shape. Such sections are subdivided into 10 -acre tracts, generally beginning at the southeast corner, and the surplus or shortage is taken up in the tracts along the north and west sides of the section.
}

Figure 2. Numbering system used for hydrologic-data sites in Utah. 


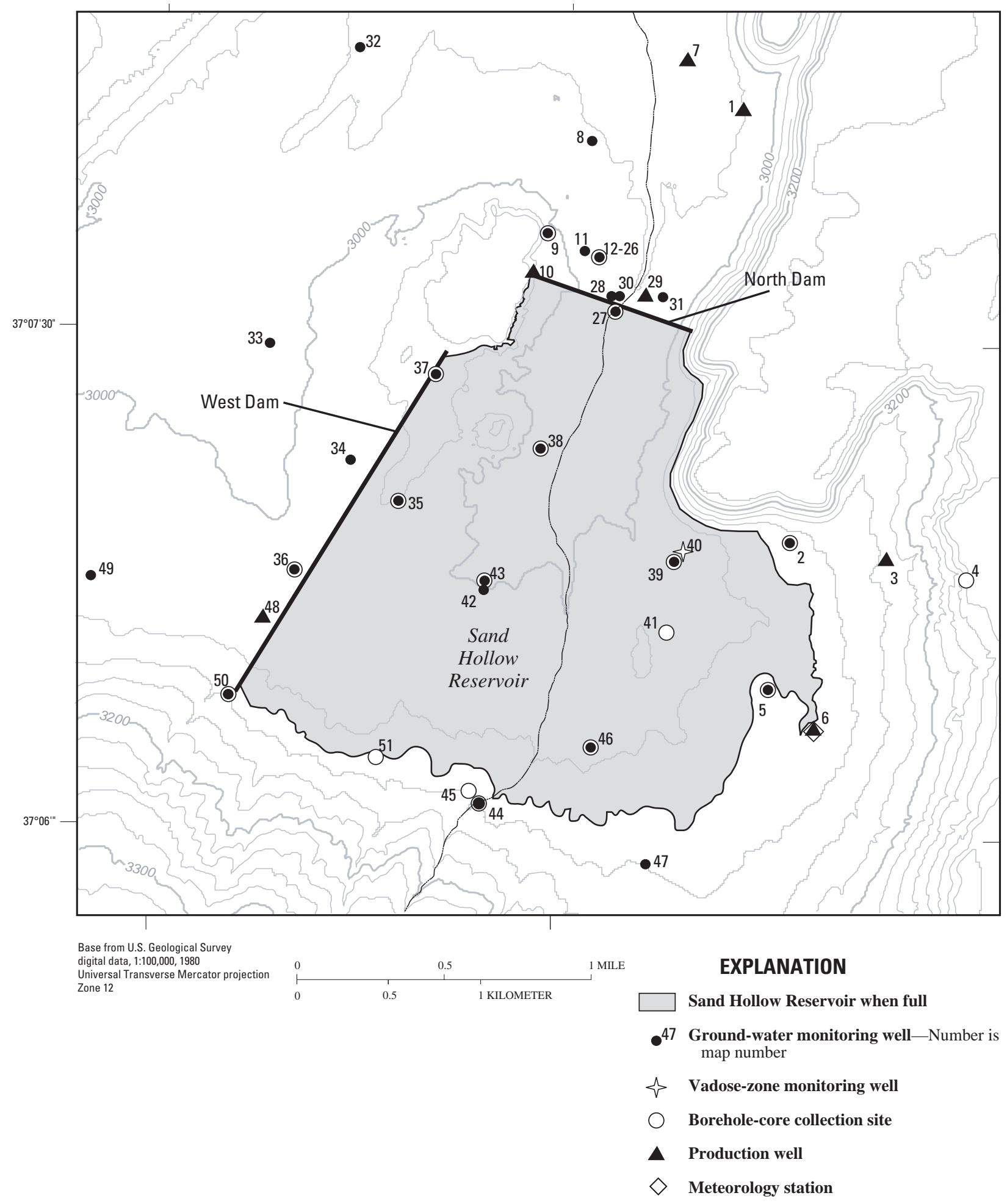

Figure 3. Location of wells, borehole-core collection sites, and weather station in Sand Hollow, Utah. 


\section{Pre- and Post-Reservoir Ground-Water Conditions at Sand Hollow, Washington County, Utah, 1995-2005}

the University of Utah Stable Isotope Ratio Facility for Environmental Research (SIRFER) Laboratory for his assistance in the analysis of stable isotope samples. Within the USGS, the authors thank John Izbicki of the Water Resources Discipline (WRD) San Diego, California, office for providing the atmospheric deposition sampler and anion analyses, and personnel from the WRD Cedar City, Utah, office for installing monitoring-well instrumentation.

\section{Hydrogeologic Setting}

Sand Hollow is a $20-\mathrm{mi}^{2}$ basin located in the southeastern part of Washington County, Utah, about 10 mi northeast of St. George (fig. 1). It is part of the Virgin River drainage basin of the Lower Colorado River Basin. Washington County is in the lowest-altitude part of Utah; the altitudes within Sand Hollow Basin range from about 3,000 to $4,200 \mathrm{ft}$.

Sand Hollow is underlain primarily by Navajo Sandstone that is either exposed at the surface or covered by a veneer of soil or surface-flood basalts (Hurlow, 1998). Although the total stratigraphic thickness of the Navajo Sandstone in this region is more than 2,000 ft, much of this has been eroded off within the study area, resulting in a sandstone thickness ranging from a few hundred to more than 1,200 ft thick. The Navajo Sandstone is characterized as fine-grained quartzose sandstone loosely cemented with calcite (Cordova, 1978). Predominant cross-bedding features reflect its eolian depositional environment (Hurlow, 1998). Because the Navajo Sandstone at Sand Hollow is only loosely cemented and well sorted, it has a relatively high porosity and permeability. Laboratory porosity and saturated hydraulic conductivity, as determined from core samples within the study area, ranged from 20 to 27 percent and 0.03 to $1.38 \mathrm{ft} / \mathrm{d}$, respectively (Heilweil and others, 2004). Depth to the water table prior to the completion of the reservoir ranged from about 50 to $150 \mathrm{ft}$ below land surface in the central and northern parts of the basin (table 1), providing a substantial volume of vadose zone available for conversion to ground-water storage. These properties make the Navajo Sandstone of Sand Hollow a good target for aquifer storage and recovery.
Methods

\section{Water-Level Data}

Water levels were measured with both steel and electric tapes in 44 observation wells in Sand Hollow Basin from 1995 through 2004 (tables 1 and 2). Six wells have been measured monthly by the WCWCD since 1995 and eight additional wells were added to the monthly monitoring network in August 2001, prior to the inception of the reservoir in March 2002. Wells measured monthly by the WCWCD have had sporadic check measurements performed by USGS personnel for quality assurance.

\section{Ground-Water Samples}

Ground-water samples were collected from open 4-in.-diameter boreholes, 1- and 2-in.-diameter polyvinyl chloride (PVC) piezometers, and production wells for chemical analysis. Water samples from the open 4-inchdiameter boreholes and the 2-in.-diameter piezometers were collected by using an air-operated submersible piston pump. Water samples were collected from the 1in.-diameter piezometers by using Waterra valves with 5/8-in.-diameter polyethelene tubing. A minimum of three casing volumes (or until specific conductance stabilized) was purged from all of the boreholes and wells prior to sample collection. Samples were collected in clean polyethelene bottles and filtered with 0.45 -micron disposable filters. Samples for metals analysis were preserved with 7.7-normal nitric acid.

Dissolved-gas samples were collected as water samples in copper tubes and as gas samples with in-situ diffusion samplers. The copper-tube collection method for dissolved gases is described by Stute and Schlosser (2001). The diffusion sampler-method is described by Sheldon (2002). The diffusion sampler consists of a small copper chamber (about $0.05 \mathrm{in}^{3}$ ) with gas-permeable membranes. Samplers were installed at the depth of the perforated zone in each well and allowed to equilibrate with the water for 24 hours. These samples were quickly removed and cold-welded by using a pinch-off tool. 


\section{Surface-Water Samples}

Surface-water samples were collected from the Virgin River, Sand Hollow Reservoir, and the main ephemeral wash near the WD 8 observation well (map number 44 in fig. 3, table 1) for chemical analysis. Samples were filtered with 0.45-micron disposable membrane filters attached to a peristaltic pump. Samples for metals analysis were preserved with 7.7-normal nitric acid.

\section{Chemical Analyses}

Ground-water, surface-water, and precipitation samples collected during this study were analyzed for (1) major and minor cations and anions, (2) selected trace elements, (3) stable isotopic ratios of carbon, oxygen, and hydrogen, (4) carbon-14 $\left({ }^{14} \mathrm{C}\right)$ and tritium, and (5) dissolved gases including chlorofluorocarbons, nitrogen, argon, krypton, neon, and helium. All major and minor cations and anions, as well as trace elements, were collected by using USGS procedures described by Wilde and others (1998). These were analyzed by the USGS National Water-Quality Laboratory in Denver, Colorado, the USGS in San Diego, California, and the Los Alamos National Laboratory in Los Alamos, New Mexico. Water samples for ${ }^{14} \mathrm{C}$ and stable-carbon isotopes were collected according to procedures described by Coplen and others (1996) and analyzed by the University of Waterloo in Waterloo, Ontario. Water samples for the stable isotopes of hydrogen and oxygen were collected according to procedures described by Coplen and others (1996) and analyzed on a Finnigan Delta S isotope ratio mass spectrometer at the University of Utah SIRFER Laboratory. Tritium samples were analyzed for helium-3 with the tritium in-growth method (Clarke and others, 1976). Helium-3 and other dissolved-gas concentrations were analyzed by using both quadrapole and MAP mass spectrometers at the University of Utah Dissolved Gas Service Center. The mass-spectrometer analysis provides the relative mole fractions of dissolved gases. The dissolved-gas concentration of the water sample is then calculated based on Henry's law relations by using field measurements of total dissolved-gas pressure and water temperature.

Four vadose-zone pore-air samples were collected from ports at a $45-\mathrm{ft}$ depth in the Slope 1B borehole (map number 40 in fig. 3 , table 1) and at a $96.7-\mathrm{ft}$ depth in the Slope 2 borehole (map number 2 in fig. 3, table 1) for analysis of stable carbon- $13\left(\delta^{13} \mathrm{C}\right)$. Samples were collected from 3/8-in.-diameter copper tubes with 0.3 -ftlength mesh screens installed in these boreholes and backfilled with silica sand adjacent to the ports and bentonite clay elsewhere to minimize vertical contamination. After removing the equivalent of three casing volumes of pore air from the copper tubing with a peristaltic pump, gas samples were collected and sealed in evacuated mylar balloons. The pore-air samples were analyzed by Geochron Laboratories in Cambridge, Massachusetts, and the data were used for correcting ground-water ${ }^{14} \mathrm{C}$ ages.

\section{Meteorology and Precipitation Data}

Meteorology data were collected at a weather station (map number 6, fig. 3) in Sand Hollow from January 13, 1998, through September 20, 2004.

Parameters measured were temperature, wind speed, wind direction, precipitation, relative humidity, and solar radiation. Instruments used were a Vaisala Temperature and RH probe, RM Young Wind Monitor, Weathertronics tipping bucket rain gage, and a Matrix MK 1-G Sol-AMeter with a spectral response from 0.35 to 1.15 microns. Sensors collected data every minute, with average hourly values, except for cumulative values of precipitation, stored on a data logger. The anemometer at the Sand Hollow weather station began to under-measure wind speeds in 2002, probably as the result of bearing failure. To correct for this, average daily and monthly wind speeds for 1999-2001 and 2002-04 were compared. The winds speeds in the later period were adjusted by adding the instrument threshold of $1.5 \mathrm{ft}$ per second to the average hourly wind speeds.

Atmospheric-deposition samples for individual storms were collected for chemical analyses by using a 0.5-ft-diameter brass funnel draining into a 250-milliliter high-density polyethylene bottle. Composite atmospheric-deposition samples also were collected at multiple-month intervals for water-quality analyses. The sampler consisted of a 3-in.-diameter straight-sided Buchner funnel at a height of about $3 \mathrm{ft}$ above ground supported by a stake and connected with copper tubing to a 1-liter plastic sample bottle buried about $1 \mathrm{ft}$ below ground. A thin (0.5-in.) layer of mineral oil in the bottle was used to minimize evaporation of water (Friedman and others, 1992). To sample both wet fall and dust deposition between rainfall events, the funnels for both the individual storms and the multiple-month composite samples were not rinsed. Rather, only particulate matter, such as insect debris and bird droppings, was removed during routine maintenance. 


\section{Pre- and Post-Reservoir Ground-Water Conditions at Sand Hollow, Washington County, Utah, 1995-2005}

\section{Temperature of Reservoir Water}

Continuous water temperature measurements were made in Sand Hollow Reservoir for both turbulent transfer evaporation calculations and for evaluating effects of changing viscosity on seepage rates beneath the reservoir. A string of five thermisters was installed in the deepest part of Sand Hollow Reservoir, about $300 \mathrm{ft}$ from the North dam. The thermisters were attached to a floating buoy at depths of $0.3,3,10,16$, and $33 \mathrm{ft}$ or bottom of the reservoir, if shallower. The thermisters are reported to have an accuracy of less than $0.5^{\circ} \mathrm{C}$ over the temperature range of 0 to $35^{\circ} \mathrm{C}$. Temperature data were collected from January 30, 2003, through September 21, 2004. However, because of instrument malfunctions, data are missing for the thermisters from May 6 to August 4, 2003. Data also are missing for the thermister at the $3.3-\mathrm{ft}$ depth from August 4 to October 9, 2003, and the thermisters at the $0.3-\mathrm{ft}$ and 3.3-ft depths from May 4 through September 21, 2004.

\section{Evaporation and Artificial Recharge}

To calculate artificial recharge to the Navajo aquifer underlying Sand Hollow Reservoir, the following water-budget equation was used:

$$
R=I_{s w}-O_{s w} \pm S-E
$$

where

$R$ is recharge,

$I_{s w}$ is surface-water inflow,

$O_{s w}$ is surface-water outflow,

$S$ is change in surface-water storage, and

$E$ is evaporation.

Surface-water inflow and outflow to Sand Hollow Reservoir, along with reservoir-stage measurements, were recorded monthly by the WCWCD. Changes in surface-water storage were calculated from reservoirstage measurements and stage-volume relations for the reservoir (Washington County Water Conservancy District, written commun., 2004).

Evaporation from Sand Hollow Reservoir was determined by using multiple methods to develop more confidence in evaporation estimates and to assess simple and cost-effective methods for estimating evaporation. Evaporation from a reservoir surface is a function of climatic conditions, water temperature, and the reservoirsurface area. There are numerous methods for measuring and estimating evaporation from a reservoir that vary in complexity from simple temperature index calculations to complete measurement of the energy balance and fluxes (Warnaka and Pochop, 1988; Winter and others, 1995). For this study, the Jensen-Haise and turbulenttransfer methods were calculated by using climate date from the Sand Hollow weather station. These results are compared to long-term average pan evaporation measurements and Penman evaporation calculations for St. George, Utah (Western Regional Climate Center, 2004).

\section{Pan Evaporation}

Pan evaporation was measured in St. George, Utah, from 1869 to 1993 with a standard class A pan (Western Region Climate Center, 2004). Pan evaporation for winter months (December - February) was not measured because of freezing temperatures. Pan-evaporation data from long-term records at nearby Boulder City, Nevada, and Wahweap, Utah, were collected year round, and indicate that 7 to 10 percent of annual evaporation occurs in the winter months. Pan-evaporation data must be corrected to account for the thermal effects of the pan and ground on the evaporation rate. Typically a coefficient of 0.6-0.8 is used to make this correction.

\section{Penman Evaporation}

The general Penman equation (Winter and others, 1995) is a simplified energy budget approach that requires temperature, relative humidity, wind speed, net solar radiation, and soil or water temperature data. Penman evaporation was calculated by the Western Regional Climate Center (2004) with climate data from St. George, Utah.

\section{Jensen-Haise Evaporation}

Air-temperature and solar-radiation data from the Sand Hollow weather station were used with the JensenHaise equation to calculate evaporation. In detailed comparisons with other methods, the Jensen-Haise method has been shown to be reasonably accurate (Winter and others, 1995). There are several forms of the Jensen-Haise equation. For this study, the version described by McGuinness and Bordne (1971) is used:

$$
P E T=\{[((0.014 T a)-0.37)(Q s)] 0.000673\} 2.54
$$


where

PET is potential evaporation in centimeters,

$\mathrm{Ta}$ is air temperature, in degrees Fahrenheit, and

$Q s$ is solar radiation, in calories per square centimeter per day.

Daily and monthly evaporation was calculated with the Jensen-Haise method. Because the method was developed for periods longer than 5 days (Winter and others, 1995), daily evaporation calculated with this method was used only for preliminary comparison with the turbulent-transfer method. Final analysis of the differences between the two methods was done on a monthly basis.

\section{Turbulent-Transfer Evaporation}

The turbulent-transfer method calculations for this study use Brutsaert's formulation of the Businger-Dyer model (Brutsaert, 1982). Evaporation was calculated with the program "trbxfr" in the Image Processing Workbench (IPW) software package, version 2 (U.S. Department of Agriculture, 1999). The turbulent-transfer method calculates the flux of water vapor above a surface and requires measurements or estimates of temperature and vapor pressure calculated from two heights (both below and above the water surface; vapor pressure above the water surface is calculated from air temperature and relative humidity), wind speed, and surface-roughness length. This method generally works well in arid climates where there are large vapor-pressure gradients.

Evaporation was calculated with the turbulenttransfer method for the period February 1, 2003, through April 30, 2004, when water temperatures were measured hourly at five depths within Sand Hollow Reservoir. Calculations were done at average hourly and daily intervals and compiled into monthly estimates of evaporation. Water-temperature data near the surface was missing because of instrument failure during two time periods (May 4-August 4, 2003; May 4-September $21,2004)$. Daily average water-surface temperature, $\mathrm{Tw}_{\mathrm{ave}}$, was estimated for these missing periods by using a linear regression of water temperature with daily average air temperature in ${ }^{\circ} \mathrm{C}, \mathrm{Ta}_{\text {ave }}$, which yielded equations:

$$
\begin{aligned}
T w_{\text {ave }} & =6.587+0.0477 * T a_{\text {ave }} \\
\left(R^{2}\right. & =0.95, p<0.001) .
\end{aligned}
$$

Missing hourly water temperatures were estimated by applying a sine function to average daily water temperature. Air temperature, relative humidity and wind speed were measured at the weather station on the southeastern edge of the reservoir (map number 6, fig. 3).

\section{Viscosity Corrections for Recharge Rates}

Calculations of intrinsic permeability can be used to remove the temperature-dependent viscosity effects on recharge rates:

$$
\kappa=K \frac{\eta}{\rho g}
$$

where

$\kappa$ is intrinsic permeability,

$\mathrm{K}$ is hydraulic conductivity (Darcy velocity),

$\eta$ is dynamic viscosity,

$\rho$ is the density of water,

and $g$ is the acceleration of gravity.

The dynamic viscosity of water at $20^{\circ} \mathrm{C}$ is 1.0 centipoise $\left(6.7 \times 10^{-4} \mathrm{lb} / \mathrm{ft}-\mathrm{sec}\right)$. However, the dynamic viscosity of water varies by more than a factor of 5 , from 1.8 centipoise at $0^{\circ} \mathrm{C}$ to 0.28 centipoise at $100^{\circ} \mathrm{C}$.

Temperature data from thermisters at a depth of about 33 $\mathrm{ft}$ in the reservoir were used to calculate dynamic viscosities. The density of water does not vary substantially within the normal range of surface-water temperatures and the acceleration of gravity is not temperature-dependent. Viscosity values can, therefore, be used in the following equation to calculate viscositycorrected hydraulic conductivity values:

$$
K_{c}=K \frac{\eta}{\eta_{20}}
$$

where

$K_{c}$ is the viscosity-corrected hydraulic conductivity in $\mathrm{ft} / \mathrm{d}$,

$K$ is the actual hydraulic conductivity in $\mathrm{ft} / \mathrm{d}$ (assuming a unit vertical hydraulic gradient),

$\eta \quad$ is the calculated viscosity of water, and

$\eta_{20}$ is the viscosity of water at $20^{\circ} \mathrm{C}$. 
PRE-AND POST- RESERVOIR GROUNDWATER CONDITIONS

To evaluate the effects of artificial recharge on ground water in Sand Hollow, pre- and post-reservoir ground-water levels and chemistry data were collected and analyzed. Prior to the initial filling of the reservoir in March 2002, a water-level inventory was conducted at 26 ground-water sites by the USGS. In addition, water-level measurements have been measured monthly by the WCWCD at 6 wells since 1995 and at 14 sites since 2001.

Field water-quality parameters have been monitored and geochemical samples have been collected and analyzed at 34 ground-water sites both prior to and since the inception of the reservoir in order to asses prereservoir water quality, ground-water age and residence time, and to evaluate water-quality changes associated with artificial recharge. In addition, the chemistry of precipitation and surface water, including the Virgin River and Sand Hollow Reservoir, has been monitored to evaluate the geochemical evolution of this ground water and effects of vadose-zone salt flushing on ground water.

\section{Water Levels}

Prior to the filling of Sand Hollow Reservoir in March 2002, water-level fluctuations generally were less than $10 \mathrm{ft}$ (table 2; fig. 4), except at the WD 1 (map number 31 in fig. 3, table 1) and WD 2 (map number 11 in fig. 3, table 1) observation wells, which showed decreased water levels caused by ground-water withdrawals from nearby Well 9 (map number 29 in fig. 3 , table 1) during 2000 and 2001. The altitude of the potentiometric surface of the Navajo aquifer in Sand Hollow prior to the reservoir is shown in figure 5. Water levels were higher in the southern part of the basin and lower in the northern part of the basin. The average prereservoir hydraulic gradient was about $0.006 \mathrm{ft} / \mathrm{ft}$ (30 $\mathrm{ft} / \mathrm{mi}$ ). Ground water generally moved to the north, where it discharged as base flow to the Virgin River (Herbert, 1995). This indicates that the primary source of recharge to the Navajo aquifer prior to the reservoir was local infiltration of precipitation within Sand Hollow. The predominant south-to-north direction of ground-water flow rules out the possibility of lateral ground-water inflow to Sand Hollow from the higher-elevation Pine Valley mountains to the north or the Hurricane Cliffs to the east.
Since the reservoir began to fill in March 2002, ground-water levels have generally increased in Sand Hollow, as a result of infiltration and ground-water mounding of this artificial recharge (figs. 6 and 7). The post-reservoir hydraulic gradient is as much as $0.03 \mathrm{ft} / \mathrm{ft}$, about five times as steep as the pre-reservoir gradient. The largest water-level rises of 30 to more than $80 \mathrm{ft}$ between March 2002 and January 2005 occurred in observation wells WD 1, 2, 6, 9, and 11 (map numbers $31,11,9,37$, and 36 , respectively, in fig. 3 , table 2 ), all located within $800 \mathrm{ft}$ of the shoreline during the highest stage of the reservoir since inception through January 2005 (3,027 ft on May 11, 2004; fig. 7). These same five wells all show water-level declines from summer 2003 through winter 2003-04, corresponding to the decreased stage of the reservoir (fig. 6).

Observation wells WD 4, 5, 7, 8, 10, and 12 (map numbers $8,33,50,44,5$, and 2 , respectively, in fig. 3 , table 1) are located farther (1,600 to 3,000 ft) from the shoreline during the high stage of 3,027 ft on May 11, 2004 (fig. 7). These wells all show some water-level rise associated with recharge beneath the reservoir. The water levels in these wells, however, respond slower to this recharge and do not show the decline from summer 2003 through winter 2003-04 observed in the closer set of observation wells corresponding to the decrease in reservoir stage (fig. 4).

Observation wells WD 13 and WD RJ (map numbers 47 and 32, respectively, in fig. 3, table 1), are located at distances farther $(3,700$ and $5,200 \mathrm{ft}$, respectively) from the shoreline during the high stage of 3,027 ft on May 11, 2004 (fig. 7). Water levels in both wells rose slightly between March 2002 and summer 2004 (about 2.3 and $2.1 \mathrm{ft}$ at WD 13 and WD RJ, respectively). However, these water-level changes are within the longer-term fluctuations recorded at WD RJ since 1995 (fig. 4). Therefore, it is assumed that the mounding associated with artificial recharge beneath the reservoir did not reach these longer distances by summer 2004.

As shown in the map view of the ground-water mounding during July/August 2004, more than 2 years after filling of the reservoir began and prior to large-scale pumping of the production wells, the mounding is largest directly beneath the reservoir (fig. 7). The potentiometric contours indicate that ground water is moving laterally away from the reservoir in all directions, with the steepest gradient to the north toward the Virgin River. 


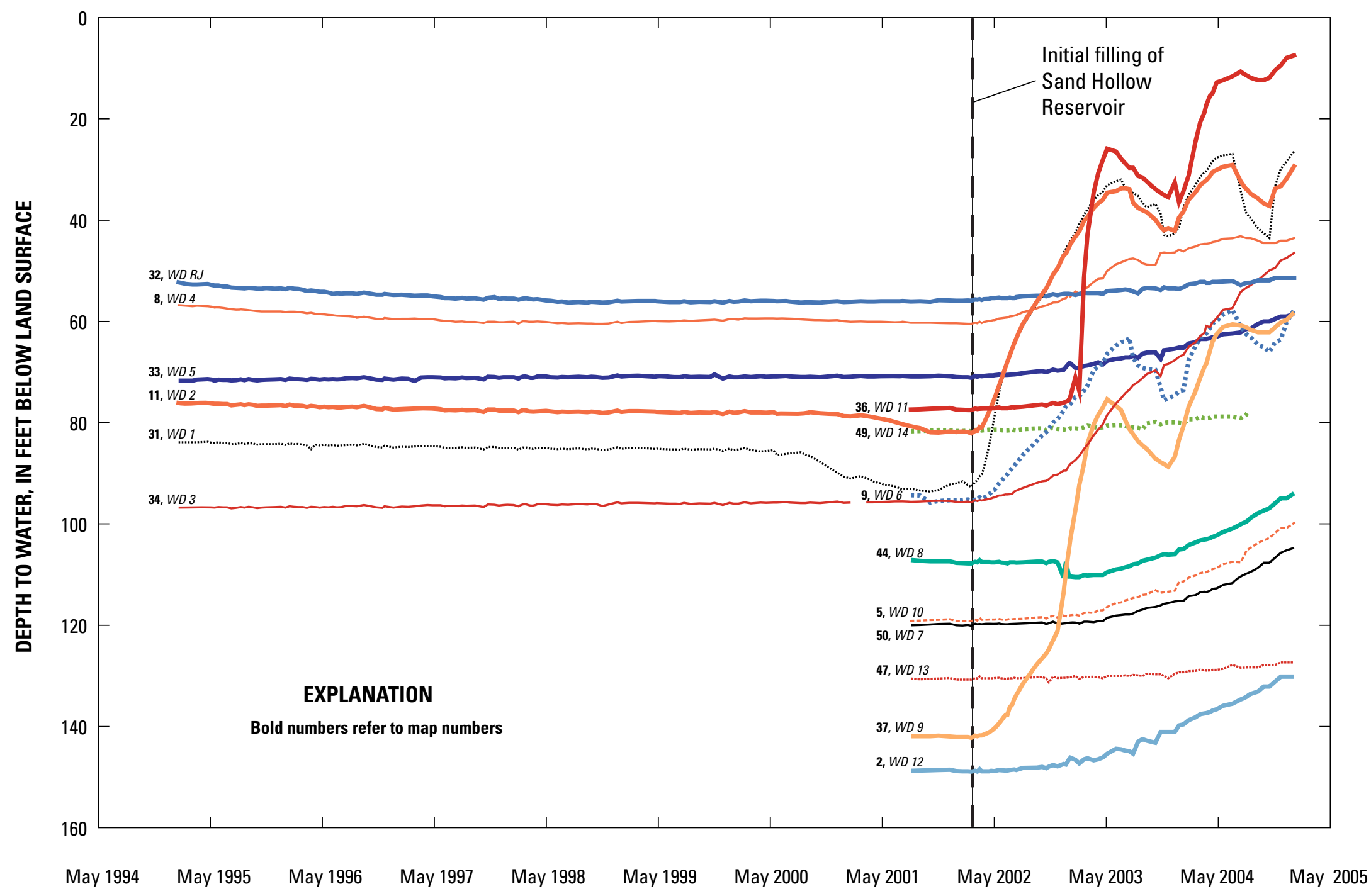

Figure 4. Water level in selected wells in Sand Hollow, Utah, 1995-2005 


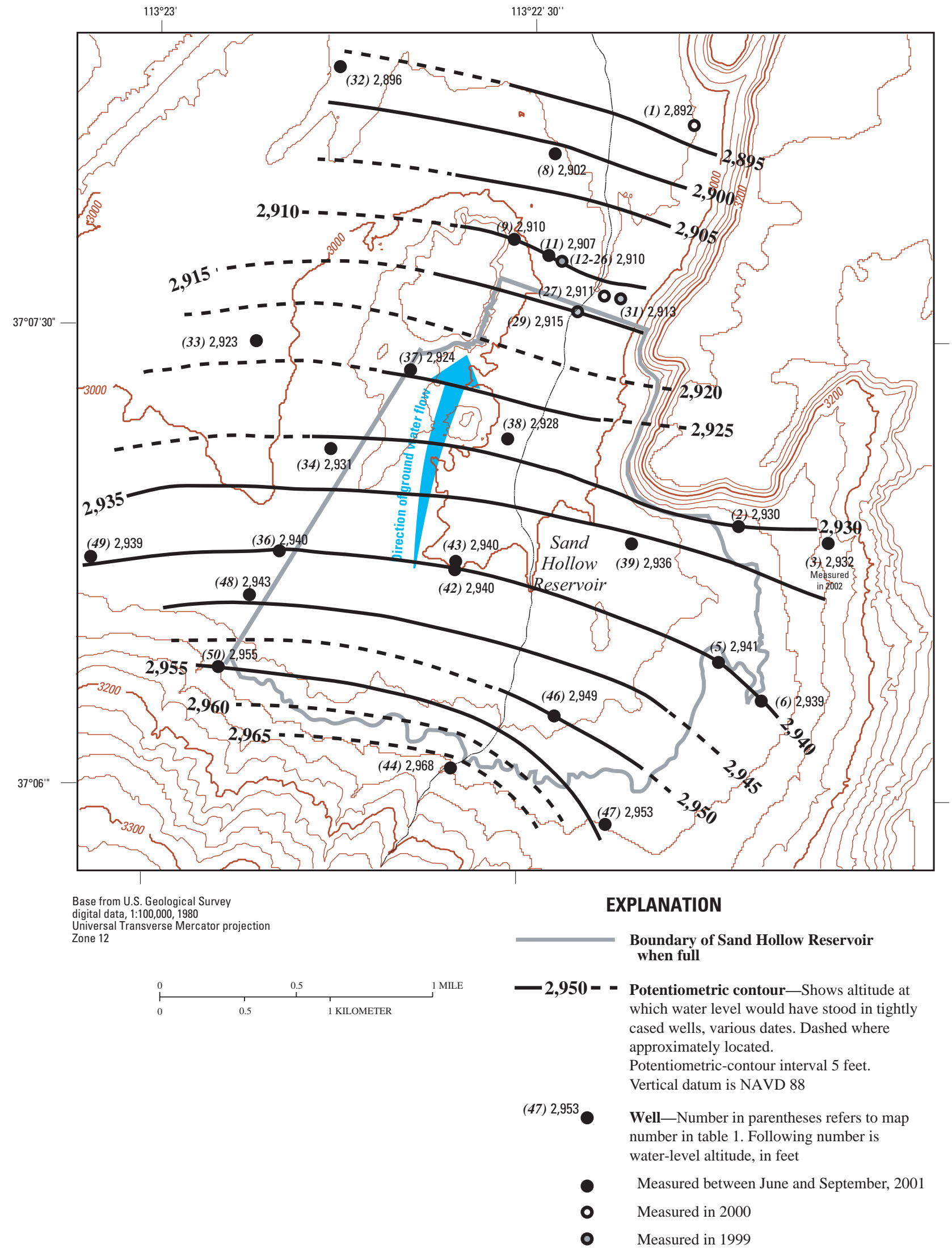

Figure 5. Potentiometric surface of the Navajo aquifer prior to completion of the reservoir, Sand Hollow, Utah. 


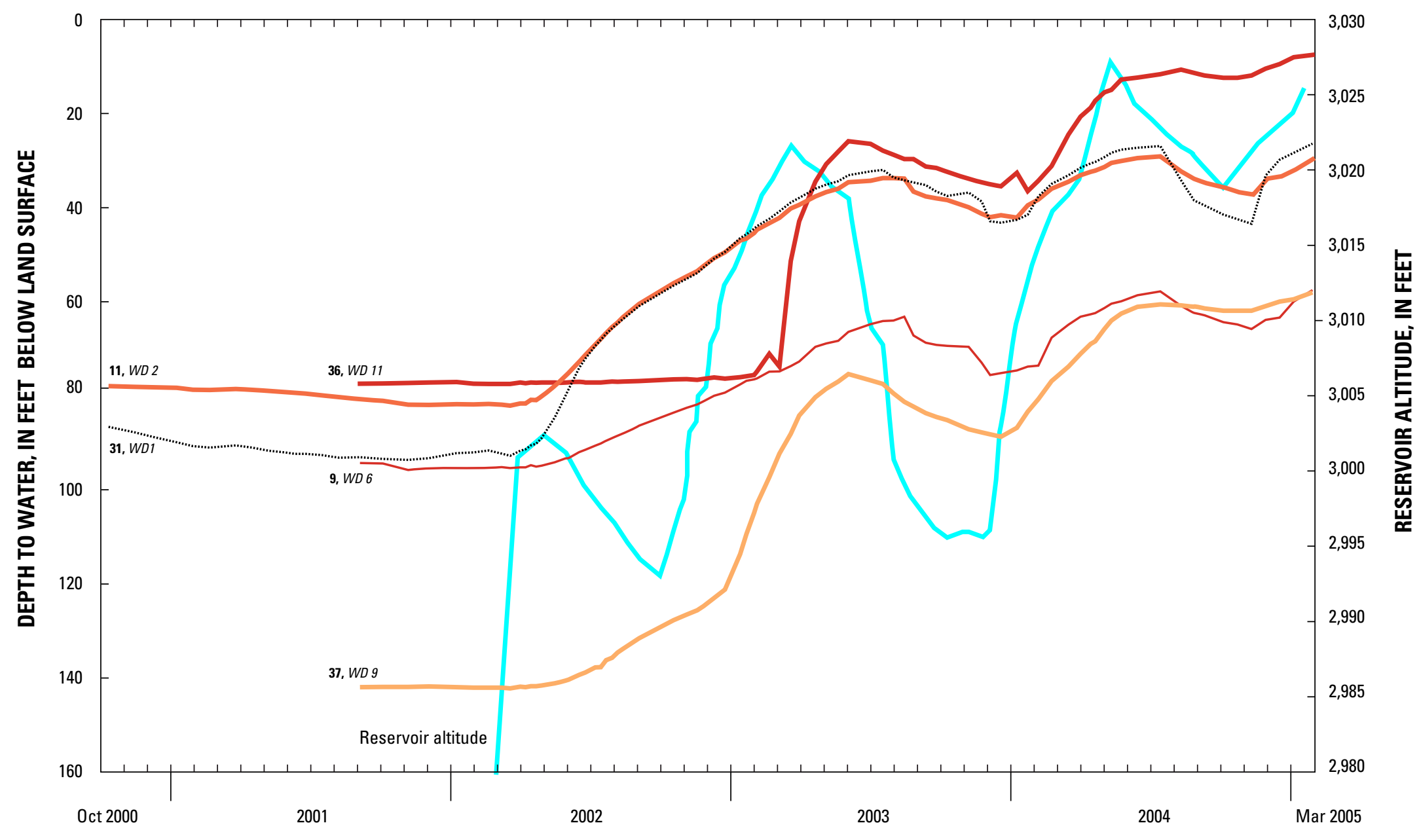

Figure 6. Relation between water level in selected wells and reservoir altitude, Sand Hollow, Utah, 2000-05. 


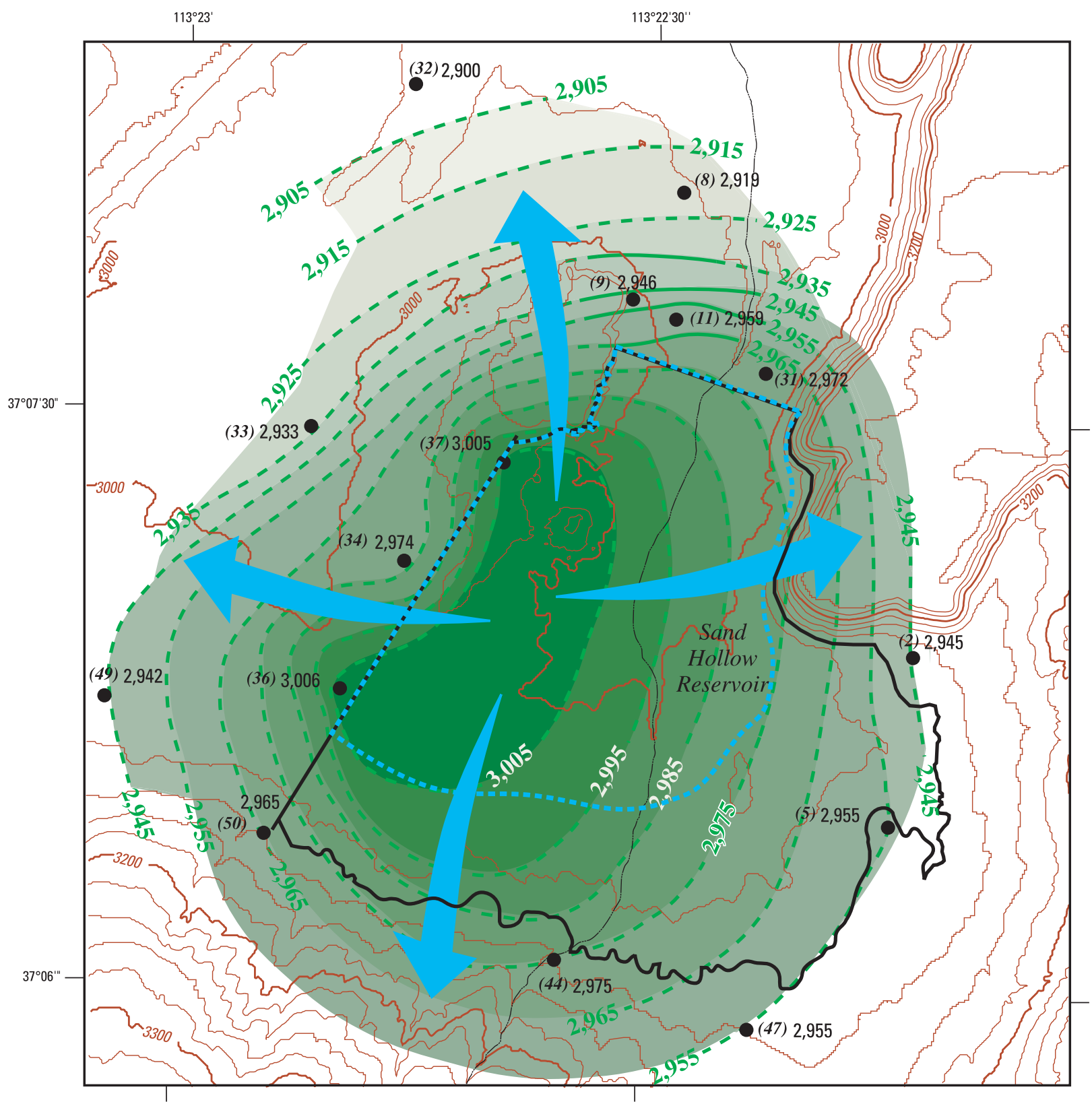

Base from U.S. Geological Survey digital data, 1:100,000, 1980

Universal Transverse Mercator projection

Zone 12

\section{EXPLANATION}

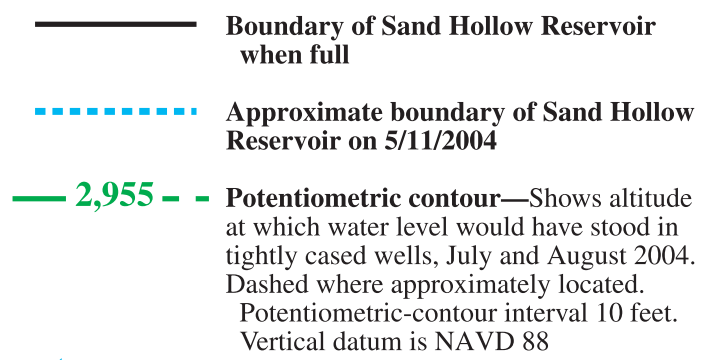

Direction of ground-water flow

(47) 2,955

Well-Number in parentheses refers to well number in table 1 . Bold number is water-level altitude

Figure 7. Potentiometric surface of the Navajo aquifer in 2004, after completion of the reservoir and prior to pumping of production wells, Sand Hollow, Utah. 


\section{Precipitation}

From January 1998 through September 2004, the maximum daily and monthly precipitation measured at the weather station at Sand Hollow occurred during September 1998 and was 1.3 and 3.7 in., respectively. Total annual precipitation at Sand Hollow from 1998 through 2004 averaged $6.7 \mathrm{in}$., ranging from 2.5 to 13.2 in. (fig. 8). Total annual precipitation for St. George from 1998 through 2004 was similar to that for Sand Hollow, averaging $7.2 \mathrm{in}$. and ranging from 1.5 to $14.0 \mathrm{in}$. This period was slightly drier than the longer-term average annual precipitation at St. George of 8.1 inches from 1893 through 2004 (Western Regional Climate Center, 2004). Total monthly precipitation at Sand Hollow is shown in figure 9.

The precipitation-weighted mean concentration of atmospheric chloride $(\mathrm{Cl})$ deposition at the Sand Hollow weather station (altitude 3,070 ft) is $0.8(+/-0.3) \mathrm{mg} / \mathrm{L}$, based on eight 6-month atmospheric-deposition samples collected from June 1999 through September 2004 at the weather station (map number 6 in fig. 3), which ranged from 0.5 to $1.2 \mathrm{mg} / \mathrm{L}$ (Heilweil and others, in press, table 1). Three other 6-month periods were excluded because of high sulfate concentrations, which indicate possible contamination from bird droppings, decaying insect debris, or dust associated with nearby construction. The range in 6-month composite $\mathrm{Cl}$ deposition values is similar to the range in $\mathrm{Cl}$ concentrations in samples collected during 13 individual storms from October 2000 to July 2001, which ranged from 0.3 to $2.9 \mathrm{mg} / \mathrm{L}$. Bromide (Br) concentration of five multiple-month atmospheric-deposition samples collected from June 1999 through September 2002 ranged from 0.007 to 0.05 $\mathrm{mg} / \mathrm{L}$. This is similar to the $\mathrm{Br}$ concentrations measured during the 13 individual storms, which ranged from 0.007 to $0.03 \mathrm{mg} / \mathrm{L}$. Chloride-to-bromide ratios in 10 precipitation samples ranged from 37 to 287 , with an average value of 120 . Uncorrected sulfate concentration of five multiple-month atmospheric-deposition samples collected from June 1999 through September 2002 ranged from 3.0 to $4.0 \mathrm{mg} / \mathrm{L}$. The sulfate concentration of atmospheric deposition samples collected during the 13 individual storms ranged from 0.7 to $8.4 \mathrm{mg} / \mathrm{L}$ (Heilweil and others, in press, table 1).

The range of values and the relation between the stable isotopes of hydrogen $\left(\delta^{2} \mathrm{H}\right)$ and oxygen $\left(\delta^{18} \mathrm{O}\right)$ in precipitation are shown in figure 10 . The $\delta^{2} \mathrm{H}$ values of six 6-month precipitation samples collected from June 1999 through May 2003 ranged from -97.6 to -1.0 permil. The $\delta^{2} \mathrm{H}$ values of precipitation from 30 individual storms from October 2000 through November 2002 ranged from -126.4 to +4.2 permil. The median $\delta^{2} \mathrm{H}$ value for all precipitation samples collected during the study was -81.0 permil.

$\delta^{18} \mathrm{O}$ values in six multiple-month precipitation samples collected during June 1999 through May 2003 ranged from -13.0 to +2.8 permil. The $\delta^{18} \mathrm{O}$ values of precipitation from 34 individual storms from October 2000 through November 2002 ranged from -15.5 to +3.3 permil. The median $\delta^{18} \mathrm{O}$ value for all precipitation samples collected during the study was -10.8 permil. Although winter precipitation generally had lighter (more negative) stable isotopic ratios than summer precipitation, there was a very large variation in values over relatively short time periods. For example, samples collected during October 2000 show a range in $\delta^{2} \mathrm{H}$ from -16.9 to -122.1 permil.

A local meteoric water line (LMWL) was constructed by linear curve-fitting to the stable-isotope ratios of 36 precipitation samples collected at Sand Hollow during 1999-2002 (fig. 10). The equation for this LMWL is

$$
\delta^{2} H=7.61 \delta O-0.03
$$

This LMWL has a shallower slope and a smaller yintercept than the global meteoric water line, which has a slope of 8 and a y-intercept of 10 (Craig, 1961). Because of evaporation of falling precipitation in this arid climate, the slope and intercept of the LMWL is similar to other published precipitation-isotope data from other arid locations in the southwestern United States (Welch and Preissler, 1986).

Tritium concentrations in precipitation samples collected during three individual storms ranged from 9.1 to 21.0 TU. These values are consistent with the range of reported values for other recently collected precipitation samples from other sites in the southwestern United States (International Atomic Energy Agency, 2002). 


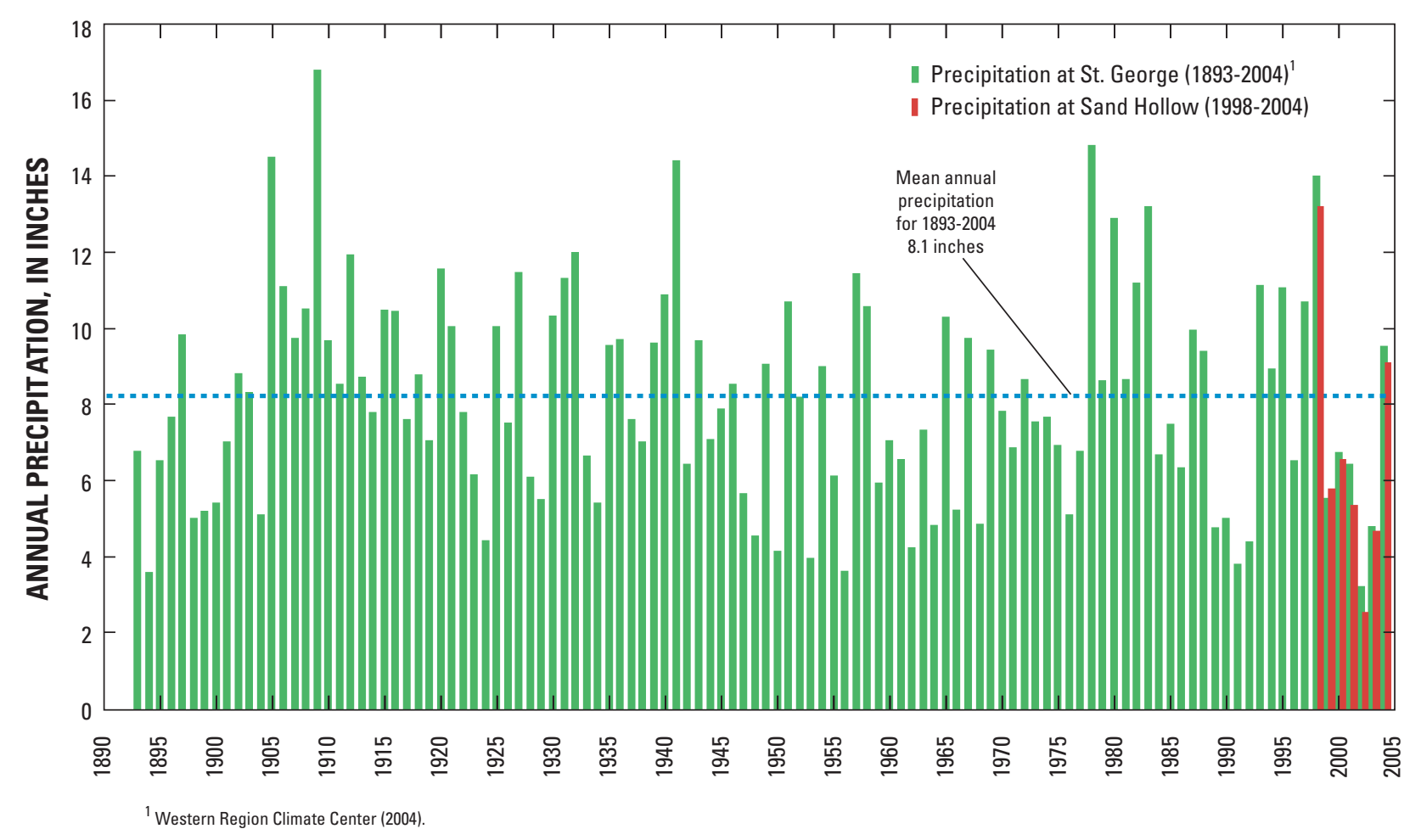

Figure 8. Annual precipitation from 1893-2004 at St. George, Utah, and from 1998-2004 at Sand Hollow, Utah.

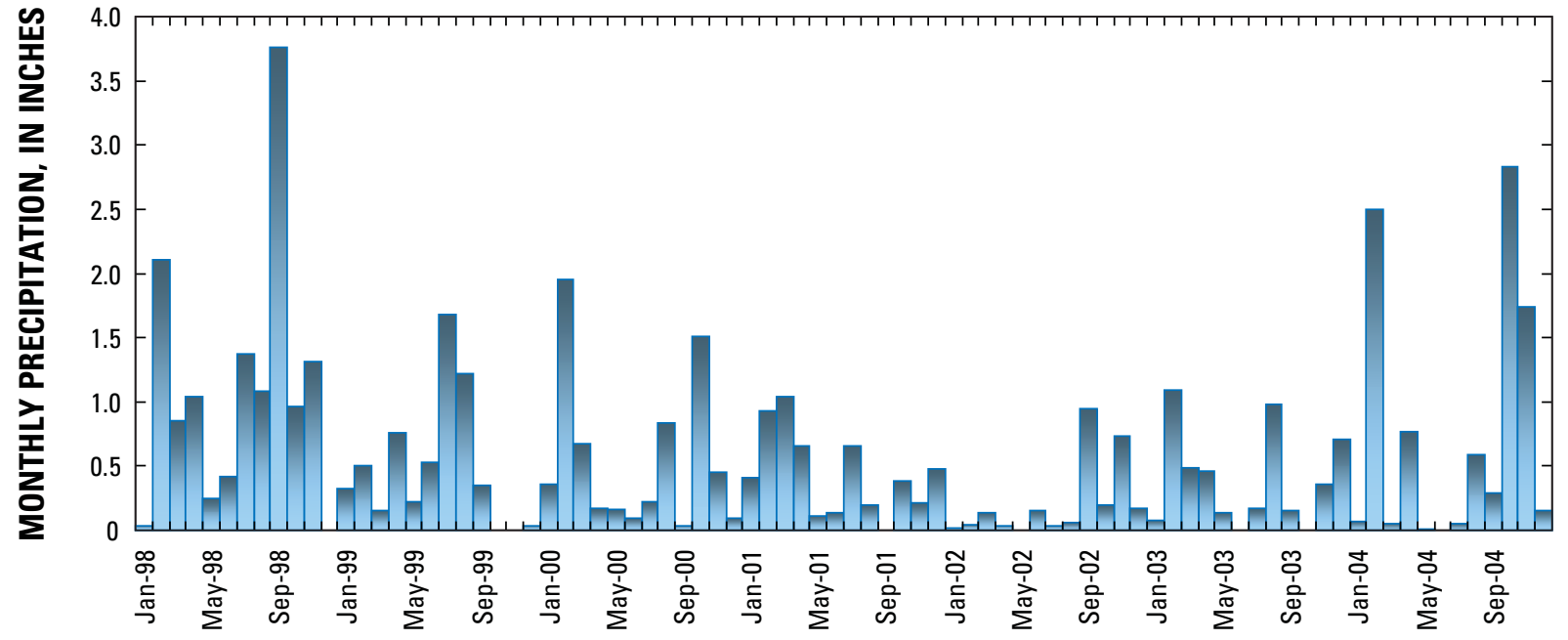

Figure 9. Monthly precipitation at Sand Hollow, Utah, 1998-2004. 


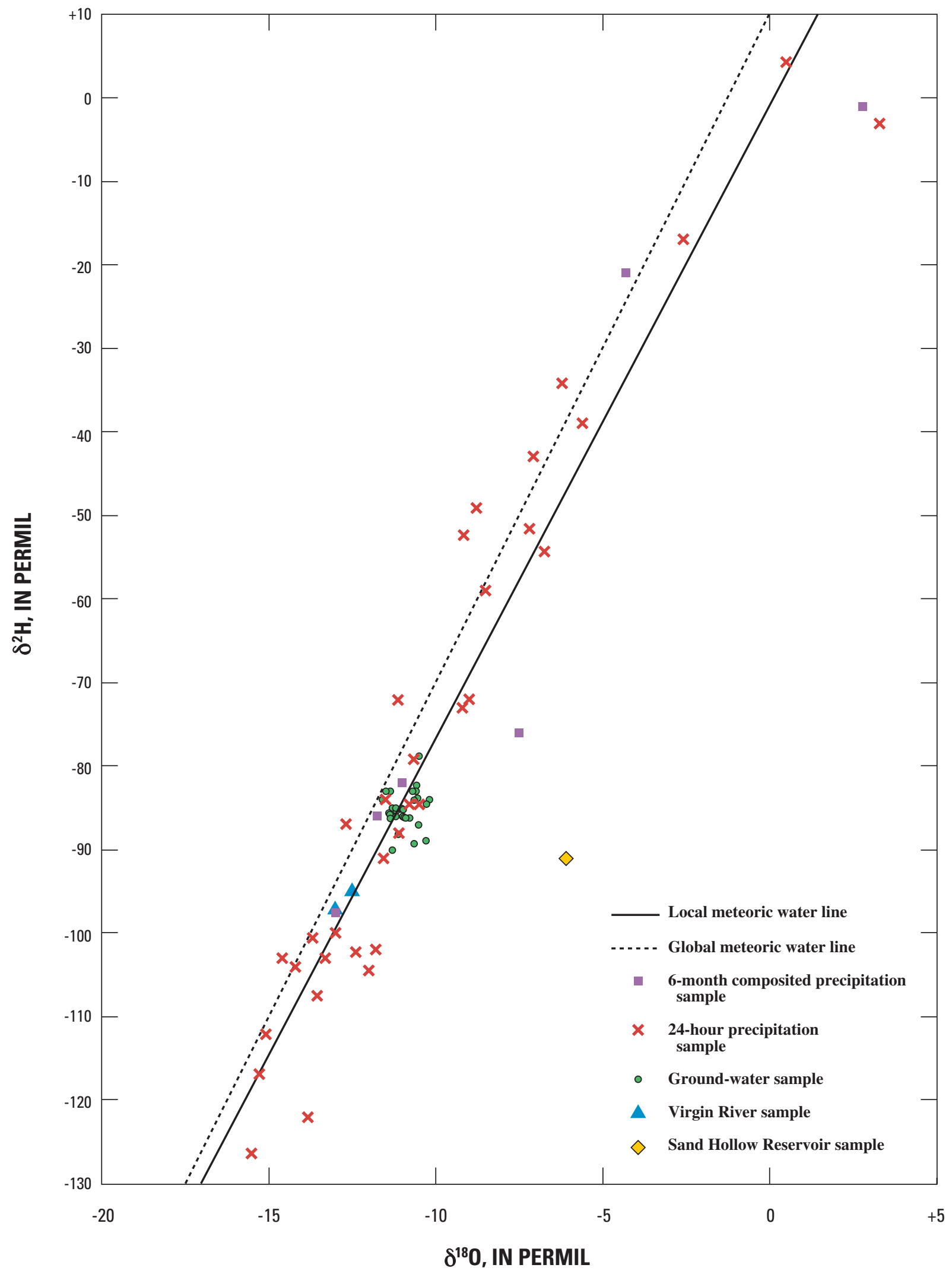

Figure 10. Relation between $\delta^{2} \mathrm{H}$ and $\delta^{18} \mathrm{O}$ values in precipitation, ground-, and surface-water samples in and near Sand Hollow, Utah. 


\section{Pre-Reservoir Ground-Water Quality}

Prior to filling of the reservoir, the specific conductance of ground water at Sand Hollow ranged from $130 \mu \mathrm{S} / \mathrm{cm}$ at WD 6 (map number 9 in fig. 3, table 1) to $620 \mu \mathrm{S} / \mathrm{cm}$ at the Basin 1 borehole site (map number 38 in fig. 3 , table 1), but generally was less than $500 \mu \mathrm{S} / \mathrm{cm}$. Corresponding dissolved-solids concentrations ranged from 88 to $370 \mathrm{mg} / \mathrm{L}$ (table 3). Natural ground water at Sand Hollow is generally a calcium-magnesium-bicarbonate-type water (fig. 11). Measured natural concentrations of nutrients including nitrate, ammonia, and phosphorus are generally less than current U.S. Environmental Protection Agency (EPA) drinking-water standards.

The pre-reservoir $\mathrm{Cl}$ concentration of ground water in Sand Hollow ranged from 6.5 to $64 \mathrm{mg} / \mathrm{L}$ (table 3). The mean $\mathrm{Cl}$ concentration from 31 ground-water sites in Sand Hollow is $22.5 \pm 12.5 \mathrm{mg} / \mathrm{L}$. It is assumed that all of the $\mathrm{Cl}$ in the unsaturated zone and the underlying aquifer is of atmospheric origin because the Navajo is a clean, well-sorted, eolian sandstone containing no evaporite or other salt deposits. However, because of the upward advective movement into the Navajo Sandstone of Clrich brines from underlying formations documented at other study sites (Kimball, 1992; Naftz and others, 1997; Heilweil and others, 2000), Cl-to-Br (Cl:Br) ratios were examined to evaluate potential $\mathrm{Cl}$ contributions from geologic sources. Such geologic sources of $\mathrm{Cl}$ typically have $\mathrm{Cl}: \mathrm{Br}$ ratios exceeding 1,000 and the ratios increase with increasing $\mathrm{Cl}$ concentration (Davis and others, 1998). However, no such trend is evident in ground water from Sand Hollow (fig. 12). Pre-reservoir $\mathrm{Br}$ concentrations ranged from 0.01 to $0.27 \mathrm{mg} / \mathrm{L}$, resulting in $\mathrm{Cl}: \mathrm{Br}$ ratios that were between 85 and 415 (table 3). Furthermore, vadose-zone pore water $\mathrm{Cl}: \mathrm{Br}$ ratios generally increase from land surface to the water table (Heilweil and others, in press), consistent with a doubling in the mean $\mathrm{Cl}: \mathrm{Br}$ ratio from 120 for atmosphericdeposition samples to 230 for ground-water samples. This indicates that some unsaturated-zone process, such as preferential uptake of $\mathrm{Br}$ by plant roots, influences ground-water $\mathrm{Cl}: \mathrm{Br}$ ratios rather than a geologic source of $\mathrm{Cl}$. Pre-reservoir sulfate concentrations in ground water ranged from 7.4 to $66 \mathrm{mg} / \mathrm{L}$. Pre-reservoir nitrate concentrations in ground water ranged from 0.29 to 3.8 $\mathrm{mg} / \mathrm{L}$.

Water temperatures in wells at Sand Hollow ranged from 17.6 to $21.0^{\circ} \mathrm{C}$, slightly warmer than the average annual air temperature of $17^{\circ} \mathrm{C}$. Although this may be partially due to the geothermal gradient, which causes an increase in temperature with depth of about 0.6 to $0.9^{\circ} \mathrm{C}$ per $100 \mathrm{ft}$ (Press and Siever, 1978), it also may be caused by the proximity of recent volcanic activity associated with Volcano Mountain just 2 mi northeast of the study area. The Utah Geological Survey designated much of Sand Hollow as the Southeast Basin of the St. George geothermal basin, a low-temperature geothermal basin (Budding and Sommer, 1986).

Water from five wells had natural arsenic concentrations of from 12 to $55 \mu \mathrm{g} / \mathrm{L}$, exceeding the EPA drinking-water standard of $10 \mu \mathrm{g} / \mathrm{L}$. Three possible sources of this elevated arsenic at Sand Hollow Basin may be the concentration by evapotranspiration of arsenic in atmospheric deposition (Scudlark and Church, 1988), the upwelling of mineralized geothermal waters (Welch and others, 2000), or the mobilization of arsenic adsorbed on the surface of hematite and magnetite nodules present within the Navajo Sandstone as a result of changes in $\mathrm{pH}$ or redox conditions. Chemical analyses of these iron oxide nodules from the Navajo Sandstone in south-central Utah showed whole-rock arsenic concentrations as high as $470 \mathrm{ppm}$ (Beitler and others, 2005).

Ratios of stable isotopes in ground water at 37 sites in Sand Hollow range from -79 to -94 permil for $\delta^{2} \mathrm{H}$ and -9.7 to -11.9 permil for $\delta^{18} \mathrm{O}$ (table 4; fig. 10). Although these values are within a much narrower range than the precipitation samples, the mean ground-water values of -86 permil for $\delta^{2} \mathrm{H}$ and -11.1 permil for $\delta^{18} \mathrm{O}$ are similar to the mean precipitation values. This supports the earlier interpretation, based on the pre-reservoir ground-water potentiometric surface, showing infiltration of local precipitation as the primary source of recharge to the aquifer. The ground-water stable-isotope ratios are generally less negative and have less variation than earlier reported stable-isotope values for the Navajo aquifer in other parts of Washington County, which ranged from -90 to -110 permil for $\delta^{2} \mathrm{H}$ and from -11.9 to -14.7 permil for $\delta^{18} \mathrm{O}$ (Heilweil and others, 2000). This indicates that natural recharge to the Navajo aquifer at Sand Hollow likely comes from a lower-altitude, localized source of precipitation within the study area, rather than precipitation in the higher-altitude Pine Valley Mountains about 12 mi north of Sand Hollow. 


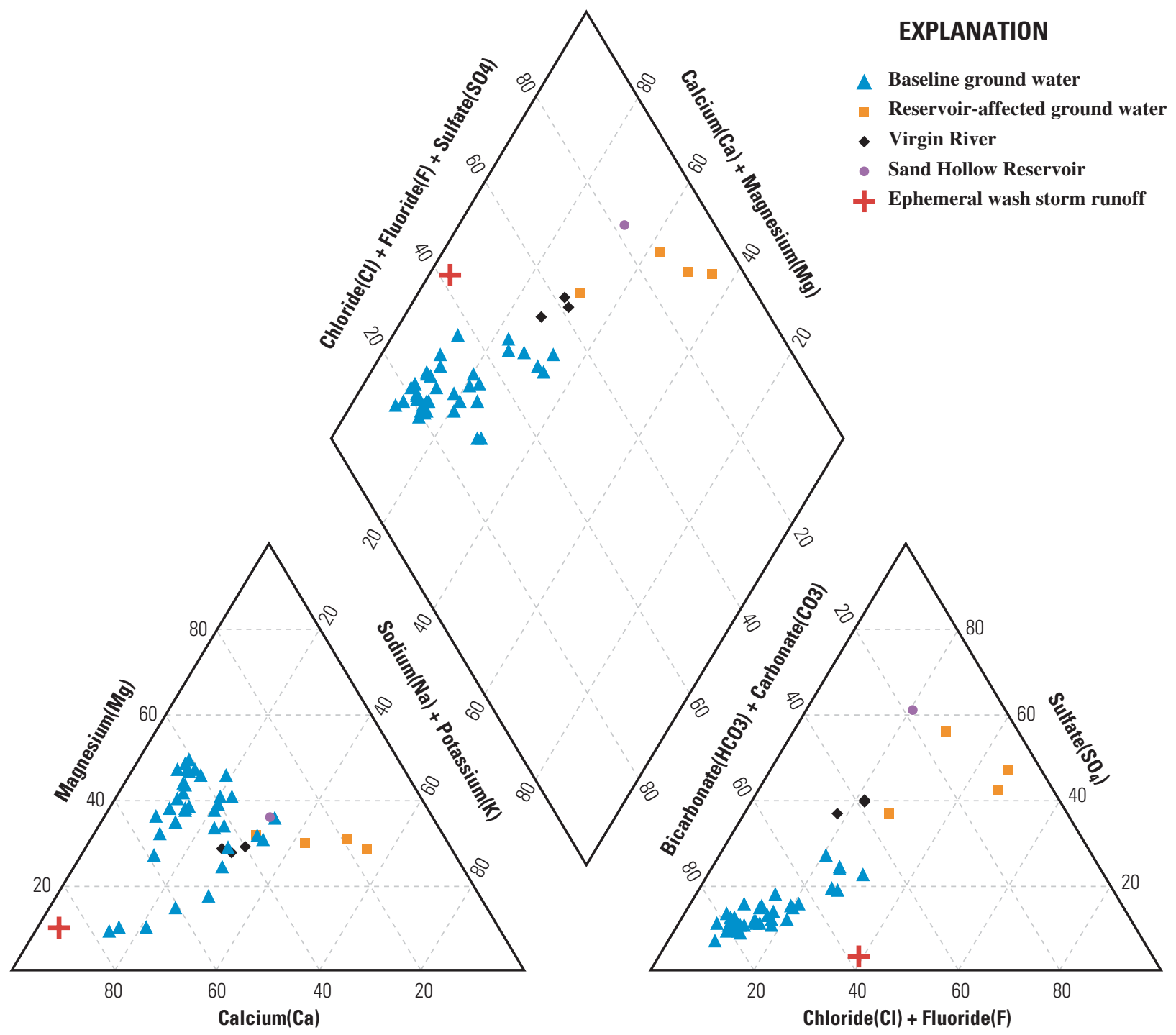

Figure 11. Major-ion chemistry of surface water, ground water, and ephemeral wash storm runoff in and near Sand Hollow, Utah. 


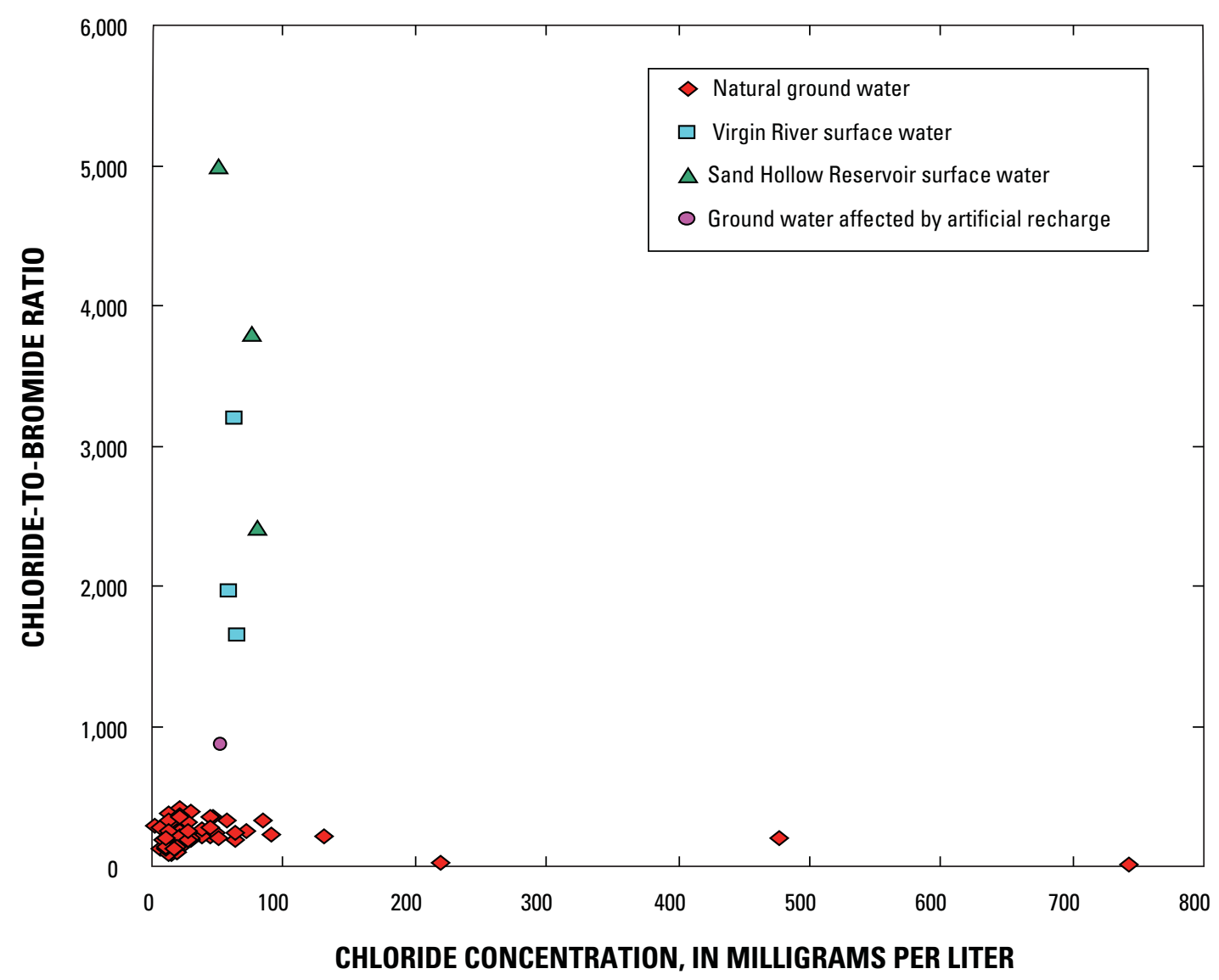

Figure 12. Relation between chloride-to-bromide ratio and chloride concentration for ground water and surface water in and near Sand Hollow, Utah.

\section{Apparent Age of Pre-Reservoir Ground Water}

Radioactive carbon-14 $\left({ }^{14} \mathrm{C}\right)$ in ground water was collected in Sand Hollow at 22 sites prior to inception of the reservoir. Concentrations of ${ }^{14} \mathrm{C}$ ranged from 14.7 to 105.3 percent modern carbon (pmc) (table 4). The radioactive half-life of carbon-14 is 5,730 years (Kalin, 2000). The stable-isotopic ratio of carbon $\left(\delta^{13} \mathrm{C}\right)$ in ground water ranged from -6.5 to -8.5 permil. Vadosezone pore air carbon dioxide $\delta^{13} \mathrm{C}$ values ranged from 15.1 to 20.9 permil. The Pearson and Hanshaw (1970) method was used with the $\delta^{13} \mathrm{C}$ values of both the ground water and the vadose-zone pore-air carbon dioxide to calculate corrected ${ }^{14} \mathrm{C}$ ages ranging from modern to 8,500 years (table 5). This indicates that some of the ground water in Sand Hollow originated as precipitation many thousands of years ago, whereas other parts of the aquifer contain much younger water. Except for the Sky
Ranch \#2 well (map number 6 in fig. 3, table 1), groundwater with modern apparent ${ }^{14} \mathrm{C}$ ages was generally located in wells with perforation depths less than $100 \mathrm{ft}$ below the water table. Ground water from wells perforated deeper than $100 \mathrm{ft}$ below the water table had apparent ${ }^{14} \mathrm{C}$ ages ranging from 500 to 8,500 years.

Ground-water samples at 37 sites in Sand Hollow for analysis of radioactive tritium $\left({ }^{3} \mathrm{H}\right)$ were collected prior to the initial filling of the surface-water reservoir. Concentrations ranged from 0 to $6.9 \mathrm{TU}$ (table 4). The lowest ${ }^{3} \mathrm{H}$ concentrations indicate water that originated as precipitation more than 50 years ago, prior to aboveground nuclear testing. The highest ${ }^{3} \mathrm{H}$ concentrations were measured in various shallow wells and indicate that some shallow parts of the aquifer have received natural recharge during the past few decades.

In conjunction with ${ }^{3} \mathrm{H}$ data, dissolved helium $\left({ }^{3} \mathrm{He}\right)$ concentrations and helium isotopic ratios were analyzed for various ground-water sites within Sand 
Hollow for estimating ${ }^{3} \mathrm{H} /{ }^{3} \mathrm{He}$ recharge year (table 5). The youngest waters were found in shallow wells screened just below the water table in high-recharge parts of Sand Hollow. ${ }^{3} \mathrm{H} /{ }^{3} \mathrm{He}$ concentrations indicate that recharge to the Navajo aquifer occurred as recently as two years proir to sampling at WD 6 (map number 9 in fig. 3, table 1). Other sites with recent recharge include WD 8 (map number 44) with recharge occurring around 1997 (water crossing the water table about 5 years before the sampling date) and at Hole O (map number 43) with recharge occurring round 1975 (water crossing the water table about 25 years before the sampling date). ${ }^{3} \mathrm{H} /{ }^{3} \mathrm{He}$ concentrations at all the other sites indicate that recharge occurred prior to the 1950s.

Chlorofluorocarbons (CFCs) were analyzed from samples at 13 sites as a potential ground-water age-dating tool prior to the initial filling of the surface-water reservoir. Concentrations of chlorofluorocarbon-11 (CFC-11) and chlorofluorocarbon-12 (CFC-12) in ground water ranged from 0.1 to 2.8 and from 0.1 to 2.4 $\mathrm{pmol} / \mathrm{kg}$, respectively (table 4). The higher concentrations approach values of water in equilibrium with the modern atmosphere. These CFC concentrations correspond to apparent CFC-11 recharge years of 1963 to 1983 and apparent CFC-12 recharge years of 1963 to 1997 (table 5). However, these relatively young ages may sometimes indicate the rapid transport of chlorofluorocarbons through pore air in unsaturated fractured rock (Thorstenson and others, 1998), rather than indicating recent recharge. ${ }^{3} \mathrm{H}$ is part of the water molecule, whereas CFCs are atmospheric gases dissolved in water that may not accurately represent the infiltration and recharge of precipitation. This may explain the poor correlation between CFC-12 and ${ }^{3} \mathrm{H}$-derived ages. Eleven of 13 the sites had ground water with modern (post1950s) apparent CFC ages, yet pre-1950s apparent ${ }^{3} \mathrm{H} /{ }^{3} \mathrm{He}$ ages.

\section{Virgin River and Sand Hollow Reservoir Surface-}

\section{Water Quality}

Surface-water-quality sampling, including both field parameters and chemical analyses, was conducted at both the Virgin River near Virgin, Utah (about $12 \mathrm{mi}$ northeast of Sand Hollow), and at Sand Hollow Reservoir. Although the two groups of samples are generally similar, there are some geochemical differences, likely caused by some combination of the following factors: (1) surface water was also brought to Sand Hollow from Quail Creek Reservoir, particularly during 2002 and the early part of 2003, when Quail Creek Reservoir was emptied for dam repairs; (2) runoff of natural precipitation into Sand Hollow Reservoir, including the flushing of surface sediments containing salts accumulating from dust and evaporation of precipitation; and (3) evaporative concentration, as is expected for a surface-water body in a warm, arid region.

Three water samples collected from the Virgin River at Virgin, Utah, had an average specific conductance value of $840 \mu \mathrm{S} / \mathrm{cm}$ (table 3). These samples were collected from August through November of 2001 and may not represent the full range of seasonal or multiyear variability. The average of seven specific conductance measurements of Sand Hollow Reservoir surface water between 2002 and 2004 is only slightly higher (870). Similarly, average sulfate and $\mathrm{Cl}$ concentrations of reservoir water $(210 \mathrm{mg} / \mathrm{L}$ and 69 $\mathrm{mg} / \mathrm{L}$, respectively) are slightly higher than average Virgin River values $(160 \mathrm{mg} / \mathrm{L}$ and $63 \mathrm{mg} / \mathrm{L}$, respectively). Nitrogen concentrations of Virgin River surface-water samples generally were very low ( 0.35 to $0.45 \mathrm{mg} / \mathrm{L})$ and were even lower $(<0.2 \mathrm{mg} / \mathrm{L})$ in the reservoir, possibly caused by nutrient uptake by biota.

Although the $\mathrm{Cl}$ concentrations of both the Virgin River and Sand Hollow Reservoir surface-water samples were similar to higher $\mathrm{Cl}$ values in pre-reservoir ground water at some locations in Sand Hollow, surface-water $\mathrm{Br}$ concentrations were very low (about $0.03 \mathrm{mg} / \mathrm{L}$ ), resulting in $\mathrm{Cl}: \mathrm{Br}$ ratios of 1,650 to 5,000 (fig. 12, table $3)$. These ratios are much higher than pre-reservoir Sand Hollow ground-water samples, which ranged from 85 to 864 (table 3, fig. 12). Therefore, the $\mathrm{Cl}: \mathrm{Br}$ ratio is a potential tracer of artificial recharge to the Navajo aquifer beneath Sand Hollow Reservoir.

The ${ }^{3} \mathrm{H}$ concentration of one Virgin River and one Sand Hollow Reservoir water sample was 1.6 and 2.5 tritium units, respectively (table 4). The $\delta^{2} \mathrm{H}$ isotopic ratios of two Virgin River water samples ranged from -95 to -97 permil, similar to one reservoir sample having -91 permil (table 4). However, the $\delta^{18} \mathrm{O}$ isotopic ratio of the reservoir sample (-6.2 permil) was more positive than the Virgin River samples (-12.5 to -13.0 permil), showing evaporative enrichment (table 4; fig. 10). Because the source of precipitation for the Virgin River is primarily from the higher-altitude Kolob Plateau, these $\delta^{2} \mathrm{H}$ and $\delta^{18} \mathrm{O}$ values are more negative than ground-water samples from Sand Hollow, which averaged -86 and -11.6 permil, respectively. Therefore, $\delta^{2} \mathrm{H}$ and $\delta^{18} \mathrm{O}$ are potential tracers for evaluating both artificial recharge and the extent of reservoir evaporation. 
Flushing of Naturally Accumulated Vadose-Zone Salts

A previous investigation (Heilweil and Solomon, in press) determined large amounts of naturally accumulated salts to be present in vadose-zone pore waters of Sand Hollow. Naturally occurring pore-water $\mathrm{Cl}$ concentrations from vadose-zone boreholes within Sand Hollow were as much as $30,000 \mathrm{mg} / \mathrm{L}$. Vadose-zone $\mathrm{Cl}$ accumulations measured at 13 borehole sites drilled in and around the reservoir prior to filling ranged from 25 to $1,500 \mathrm{mg} / \mathrm{in}^{2}$ for a 1 -in. by 1 -in. column of rock from land surface to the water table (4 to $230 \mathrm{mg} / \mathrm{cm}^{2}$ for a 1 $\mathrm{cm}$ by $1-\mathrm{cm}$ column). A geometric mean value of 180 $\mathrm{mg} / \mathrm{in}^{2}\left(28 \mathrm{mg} / \mathrm{cm}^{2}\right)$ was calculated for the area beneath the reservoir. Based on an average ratio of $\mathrm{Cl}$ to dissolved-solids concentration in ground water in Sand Hollow (table 3 ) of about 0.1 , it is estimated that the average total salt accumulation in the vadose zone beneath Sand Hollow reservoir prior to filling was about $1,800 \mathrm{mg} / \mathrm{in}^{2}$. Multiplying this salt concentration by the 1,300 -acre area of the reservoir when full (a surface altitude of 3,067 ft), it is estimated that that about 15,000 tons of salts were in the vadose zone of Sand Hollow prior to the filling of Sand Hollow Reservoir.

A shallow observation well in the Navajo aquifer along the North Dam, which was unsaturated prior to completion of Sand Hollow Reservoir, shows the flushing of these naturally accumulated vadose-zone salts. The dissolved-solids concentration of water from North Dam 3 A well (map number 28 in fig. 3, table 1; screened 15 to $25 \mathrm{ft}$ below land surface) exceeded $3,000 \mathrm{mg} / \mathrm{L}$ soon after filling of the reservoir in 2002 and decreased to about 700 $\mathrm{mg} / \mathrm{L}$ by 2004 (table 3). Similarly, elevated nitrate concentrations (as much as $18 \mathrm{mg} / \mathrm{L}$ ) also were measured at this site. Increases in nitrate (as much as $4.6 \mathrm{mg} / \mathrm{L}$ ) also have been measured at shallow observation well WD 11 (map number 36 in fig. 3, table 1). These are similar to earlier findings of salt flushing at a shallow observation well beneath a small-scale infiltration pond (map number 12 in fig. 3, table 1) during a 10-month experiment conducted from 2000 to 2001 (Heilweil and others, 2004). Although these shallow water-table concentrations exceed drinking-water standards, ground-water concentrations in nearby production wells are much lower, likely caused by dilution of these flushed salts with deeper ground water. For example, if the estimated 15,000 tons of vadose-zone salts beneath Sand Hollow reservoir is diluted with ground water in the upper $500 \mathrm{ft}$ of the aquifer in the northern half of the basin $\left(10 \mathrm{mi}^{2}\right)$, the increase in dissolved solids, besides any increase from the higher-dissolved-solids Virgin River source water, would only be about $20 \mathrm{mg} / \mathrm{L}$.

\section{Effects of Artificial Recharge on Ground-Water Quality}

Ground-water field water-quality measurements and geochemical sampling and analysis were conducted between 1999 and 2005 in Sand Hollow. This information can be used to evaluate the effects of artificial recharge on ground-water quality.

\section{Field Parameters}

Field measurements in observation and production wells closest to Sand Hollow reservoir indicate the arrival of artificial recharge to the Navajo aquifer during the first 2 years of operation. In particular, specific-conductance values and total dissolved-gas pressures have risen substantially at the shallow observation wells nearest the reservoir. Specific-conductance values at these wells all approached the average reservoir conductance of about $800 \mu \mathrm{S} / \mathrm{cm}$. Values increased from 130 to more than 800 $\mu \mathrm{S} / \mathrm{cm}$ at WD 6 (map number 9) and from 280 to 815 $\mu \mathrm{S} / \mathrm{cm}$ at WD 9 (map number 37). These increases are shown in figure 13 and table 3 . The increase in specificconductance values up to about $1,000 \mu \mathrm{S} / \mathrm{cm}$ at WD 11 (map number 36) during late 2004 and 2005 was likely caused, in part, by vadose-zone salt flushing The decrease in specific-conductance values at WD 6 during 2005 was likely a result of pumping of nearby production wells, which may have caused a reversal in hydraulic gradient and brought pre-reservoir ground-water back toward the observation well.

In-situ total dissolved-gas pressure in ground water near the reservoir showed large increases since the filling of the reservoir, caused by a combination of dissolution of entrapped air bubbles (excess air) and increased hydrostatic head associated with the rapidly rising water table. A previous investigation determined that about 10 percent of the porosity beneath the infiltration pond (map number 12 in fig. 3, table 1) was filled with trapped air rather than water under otherwise saturated conditions (Heilweil and others, 2004). The larger hydrostatic-head change associated with the reservoir, as compared with 


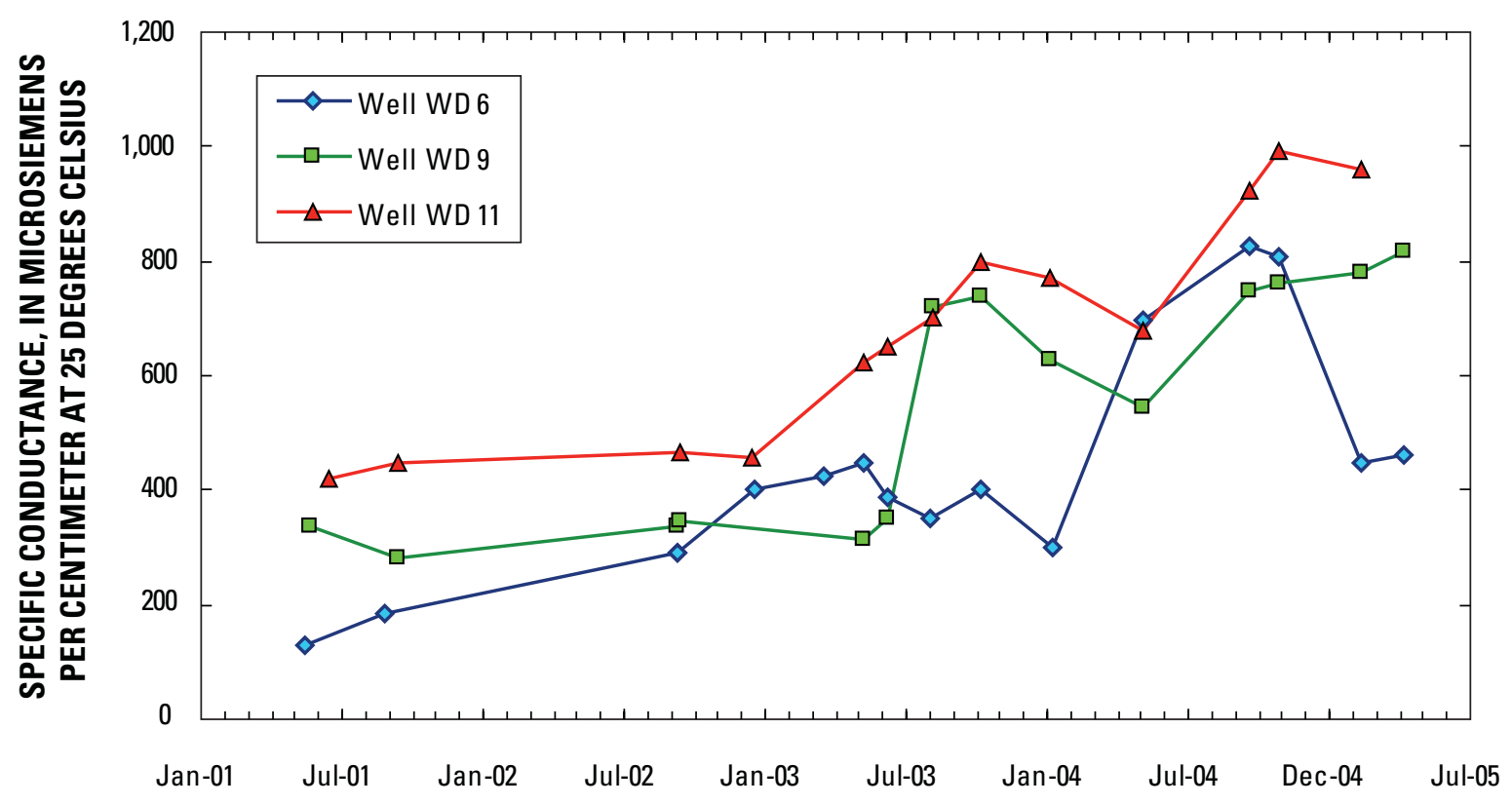

Figure 13. Specific conductance at shallow observation wells near Sand Hollow Reservoir, Utah, 2001-05.

the infiltration pond, has resulted in even more air entrapment and very high total dissolved-gas pressures. Pressure has risen from 0.9 to 1.8 atmospheres (atm) at WD 6, and from about 1 to more than 3 atm at WD 9 and WD 11 (fig. 14). This indicates that gas clogging associated with trapped air is substantially reducing the permeability of the sandstone in the vicinity of the reservoir. Previous calculations indicate that it can take years for such trapped air to re-dissolve (Heilweil and Solomon, 2004). A study of dissolved-gas concentrations near the reservoir (Solomon and Heilweil, 2004) showed that as much as 20 percent of the porosity beneath and adjacent to the reservoir may be filled with trapped air, as much as twice that of the previous infiltration pond experiment. Based on laboratory unsaturated hydraulicconductivity measurements, a 20-percent reduction in saturation may reduce hydraulic conductivity by more than an order of magnitude (from about $0.6 \mathrm{ft} / \mathrm{d}$ to about $0.03 \mathrm{ft} / \mathrm{d}$; Heilweil and Solomon, 2004, fig. 5).

\section{Geochemical Parameters}

Similar to specific conductance, dissolved-solids concentrations have risen substantially at the shallow observation wells nearest the reservoir: from 88 to 445 $\mathrm{mg} / \mathrm{L}$ at WD6, from 190 to $445 \mathrm{mg} / \mathrm{L}$ at WD 9, and from 230 to $480 \mathrm{mg} / \mathrm{L}$ at WD 11 (table 3). Similar increases in the major cations and anions also have been measured. Calcium, magnesium, sodium, sulfate, and chloride concentrations all have increased at these wells since filling of the reservoir began during March 2002. Interestingly, potassium concentrations have declined even though Virgin River and reservoir water samples have higher potassium concentrations than native ground water in the Navajo aquifer at Sand Hollow. This indicates that a geochemical sodium/potassium exchange reaction may be occurring between the native ground water and the artificially recharged reservoir water.

Although the geochemistry of shallow groundwater samples from the Navajo aquifer in the vicinity of the reservoir after the initial filling is similar to both Virgin River and Sand Hollow Reservoir surface-water samples, they show a more pronounced sodium chloride signature (fig. 11), likely caused by the flushing of vadose-zone salts. The flushing of these naturally accumulating vadose-zone salts with low $\mathrm{Cl}$ : $\mathrm{Br}$ ratios (Heilweil and others, in press) may also explain why $\mathrm{Cl}$ :Br ratios in observation wells remain well below the large ratios of as much as 5,000 measured in reservoir water. 


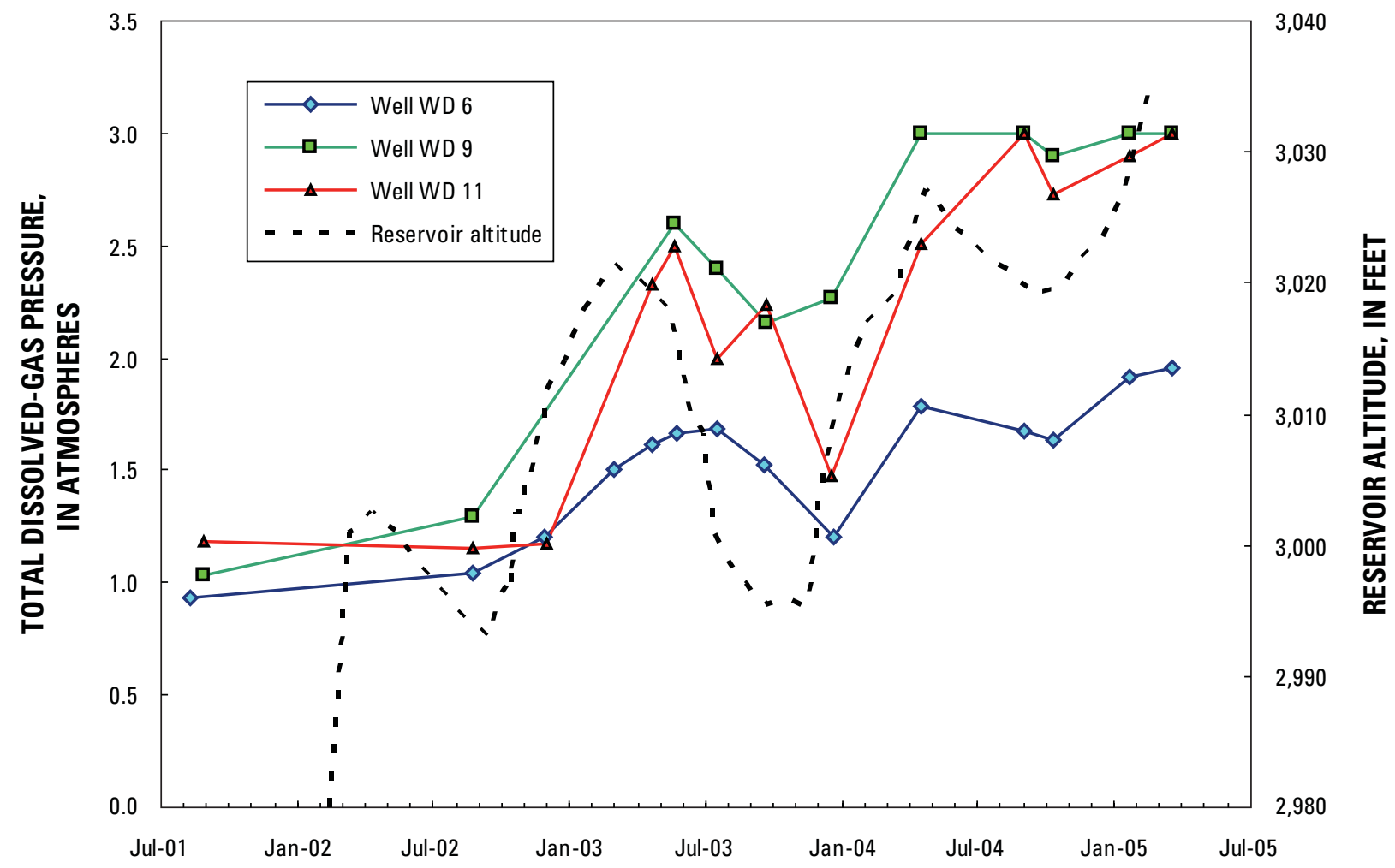

Figure 14. Relation between total dissolved-gas pressure in ground water and reservoir altitude, Sand Hollow, Utah, 2001-05.

In general, the arsenic concentration of ground water has risen in some but not all areas of the aquifer affected by artificial recharge. Arsenic in the shallowest part of the Navajo aquifer (North Dam 3A; map number 28 in fig. 3, table 1) was monitored from September 2002 through April 2005. This well is screened from 15 to 25 $\mathrm{ft}$ below land surface and was dry prior to filling of the reservoir. Concentrations of arsenic shortly after the reservoir filled were as much as $90 \mu \mathrm{g} / \mathrm{L}$ initially, but gradually decreased to a range of from 42 to $48 \mu \mathrm{g} / \mathrm{L}$ (fig. 15 , table 3). Unlike concentrations of other chemical constituents at this site, which initially showed vadosezone salt flushing yet decreased to surface-water ranges, the arsenic concentration has remained well above EPA standards for drinking water. This is similar to shallow ground-water monitoring during an earlier (2000-01) infiltration experiment at the nearby Infiltration Pond site (map number 12 in fig. 3, table 1), which also showed elevated arsenic concentrations persisting much longer than dissolved-solids or nitrate concentrations. This indicates a different process than salt flushing, such as the mobilization of arsenic adsorbed on the surface of hematite and magnetite nodules as a result of changes in
$\mathrm{pH}$ conditions. The $\mathrm{pH}$ of the infiltrating reservoir water is generally more than 8.0 , higher than the native groundwater within the Navajo aquifer in Sand Hollow. The persistence of high arsenic concentrations at the North Dam 3A well may indicate the slow release of arsenic adsorbed to these iron and magnetite oxides. The continued high arsenic concentrations do not appear to be related to fluctuations in water levels (fig. 15).

Shallow observation wells WD 6, WD 9, and WD 11 , perforated just beneath the pre-reservoir water table, had smaller increases in arsenic after the reservoir filling began. At well WD 6 (map number 9 in fig. 3, tables 1 and 3), the arsenic concentration increased from $2.0 \mu \mathrm{g} / \mathrm{L}$ on September 9, 2002, to $2.8 \mu \mathrm{g} / \mathrm{L}$ on May 3, 2004. At well WD 9 (map number 37), the arsenic concentration increased from $9.4 \mu \mathrm{g} / \mathrm{L}$ on May 23,2001 , to $13.3 \mu \mathrm{g} / \mathrm{L}$ on May 3, 2004, but then decreased to $7.3 \mu \mathrm{g} / \mathrm{L}$ on April 9, 2005. At well WD 11 (map number 36), the arsenic concentration increased from $7.3 \mu \mathrm{g} / \mathrm{L}$ on December 16 , 2002, to $17.0 \mu \mathrm{g} / \mathrm{L}$ on February 9, 2005. Arsenic concentrations at both WD 9 and WD 11 have decreased slightly since 2004 . 


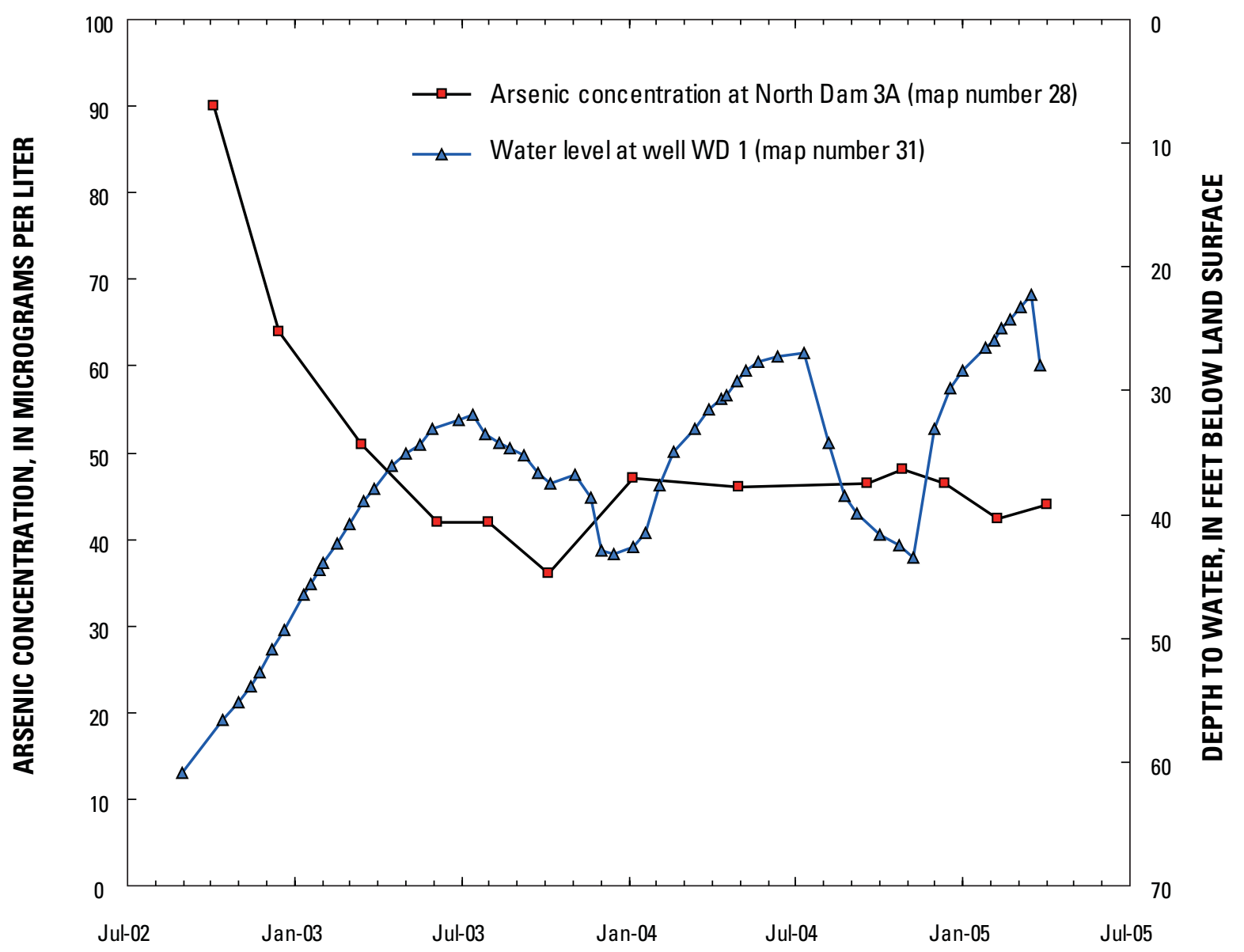

Figure 15. Relation between dissolved arsenic concentration in the North Dam 3A well and water level in the nearby WD 1 well, Sand Hollow, Utah, 200205.

Deeper production wells located just north of the reservoir and screened to hundreds of feet below the water table do not show the same increase in groundwater arsenic concentrations since the initial filling of the reservoir. At well 8 (map number 10 in fig. 3, tables 1 and 3), arsenic concentrations decreased from $16.6 \mu \mathrm{g} / \mathrm{L}$ on October 8, 2002, to $8.1 \mu \mathrm{g} / \mathrm{L}$ on September 21, 2004. At well 9 (map number 29), arsenic concentrations oscillated between 12 and $17 \mu \mathrm{g} / \mathrm{L}$ between August 30, 2001, to April 8, 2005.

\section{ASSESSMENT OF ARTIFICIAL RECHARGE}

To estimate artificial recharge beneath Sand Hollow Reservoir, evaporation rates were first calculated and compared by using five different methods (uncorrected pan, corrected pan, Penman, Jensen-Haise, and turbulent transfer) to select the most appropriate method. These evaporation rates, multiplied by the surface area of the reservoir, were then used for calculating the total monthly amount of evaporation from Sand Hollow Reservoir. Evaporation (E), along with total monthly inflows $\left(\mathrm{I}_{\mathrm{sw}}\right)$, outflows $\left(\mathrm{O}_{\mathrm{sw}}\right)$, and changes in surface water storage $(\mathrm{S})$, were used in equation (1) to calculate monthly estimated ground-water recharge beneath Sand Hollow Reservoir.

\section{Comparison of Evaporation Rates}

Average monthly and corrected average pan evaporation for 1869-1993 is listed in table 6. Uncorrected average monthly rates range from 2.68 in. in November to 13.17 in. in July. Corrected monthly pan evaporation, calculated using a correction factor of 80 percent, ranges from $2.14 \mathrm{in}$. in November to $10.53 \mathrm{in}$. in 
July. Pan evaporation rates are not calculated for the winter months (December through February) because of problems associated with freezing.

Monthly and annual Penman evaporation calculations for St. George from 1999 through 2004 are listed in table 6 . Monthly values generally range from about 3 in. in December and January to about 8 in. in July and August. Months with at least 1 day of missing data are noted with a footnote in table 6 . Some months were missing all the climate data for that month so calculations could not be made. Years 1999 and 2003 had complete data sets and annual evaporation of 72.9 and 67.6 in. respectively.

Daily Jensen-Haise evaporation was calculated from meteorology data collected at the Sand Hollow weather station from January 13, 1998, to September 20, 2004 (fig. 16). Daily evaporation rates generally varied from 0 to almost 0.5 in/day, reflecting seasonal fluctuations in daily temperature and solar radiation. Monthly evaporation estimates calculated with the Jensen-Haise equation also reflect this seasonality, generally varying from less than 1 in. during December and January to more than 10 in. during June and July. Annual estimates range from 55.3 in. 1999 to 61.2 in. in 2003 (table 6).
Daily evaporation was calculated with the turbulent-transfer method from January 2003 through April 2004 from reservoir water temperatures (fig. 17). Evaporation rates varied from 0.0 to $0.97 \mathrm{in} /$ day (fig. 18). This is a much wider range than daily evaporation calculated with the Jensen-Haise method ( 0.0 to 0.45 in/day; fig. 16). The turbulent-transfer method more accurately represents high evaporation conditions on windy days or when there are high vapor-pressure gradients between the reservoir and the atmosphere. Monthly evaporation calculated using the transfer method ranged from 1.1 to 8.7 in (table 6).

Monthly and annual evaporation estimates for all the methods are listed in table 6. Monthly evaporation calculated with the turbulent-transfer method also has a different seasonal distribution than the Jensen-Haise monthly evaporation. Turbulent-transfer method calculations during peak evaporation months (summer) are less than calculations made using the Jensen-Haise method, yet larger during the fall. Average monthly pan evaporation for $1869-1993$ multiplied by a 0.8 coefficient is generally similar to evaporation calculated with the Jensen-Haise equation.

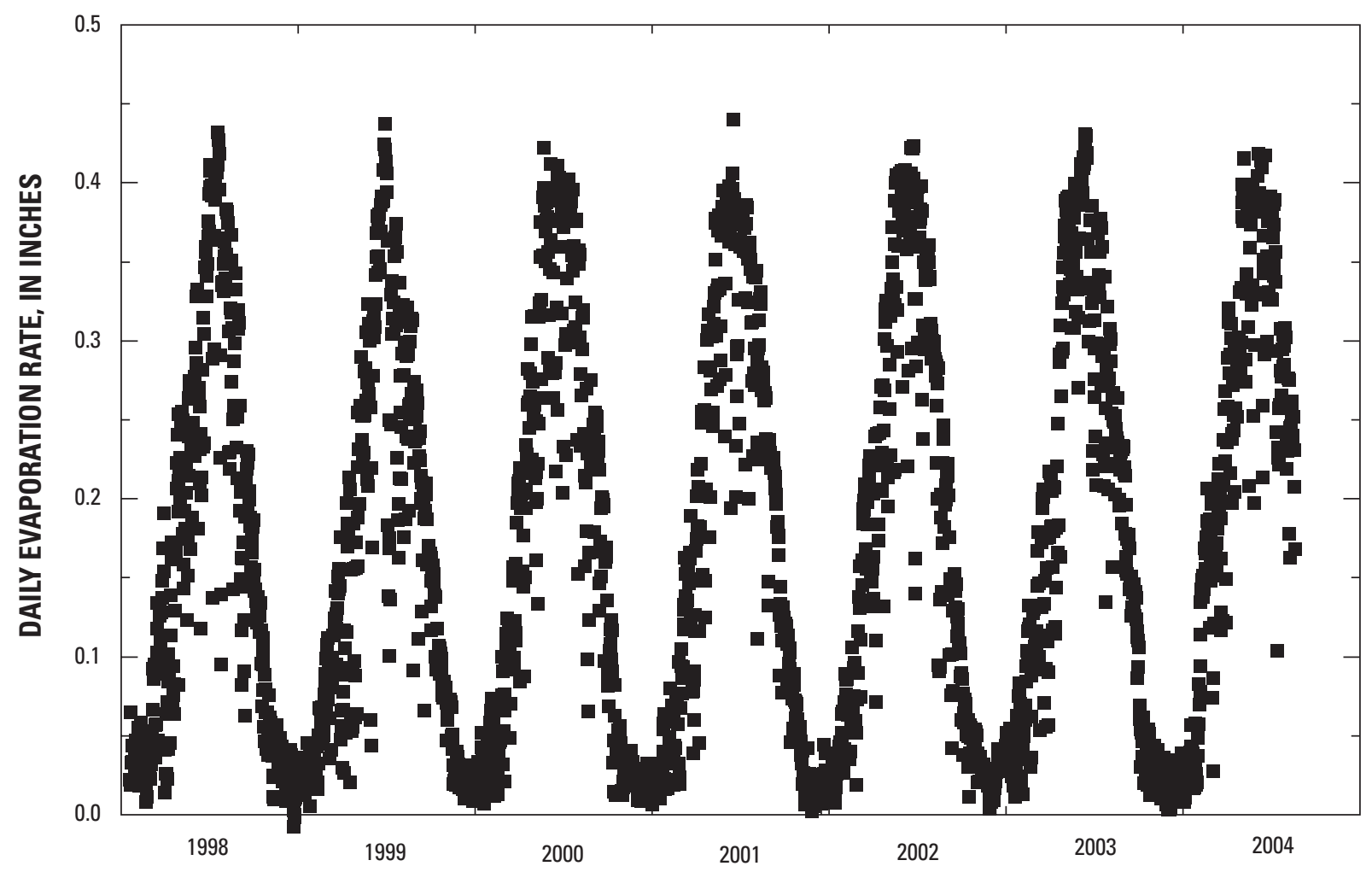

Figure 16. Daily evaporation rate calculated with the Jensen-Haise method for Sand Hollow Reservoir, Utah, 1998-2004. 


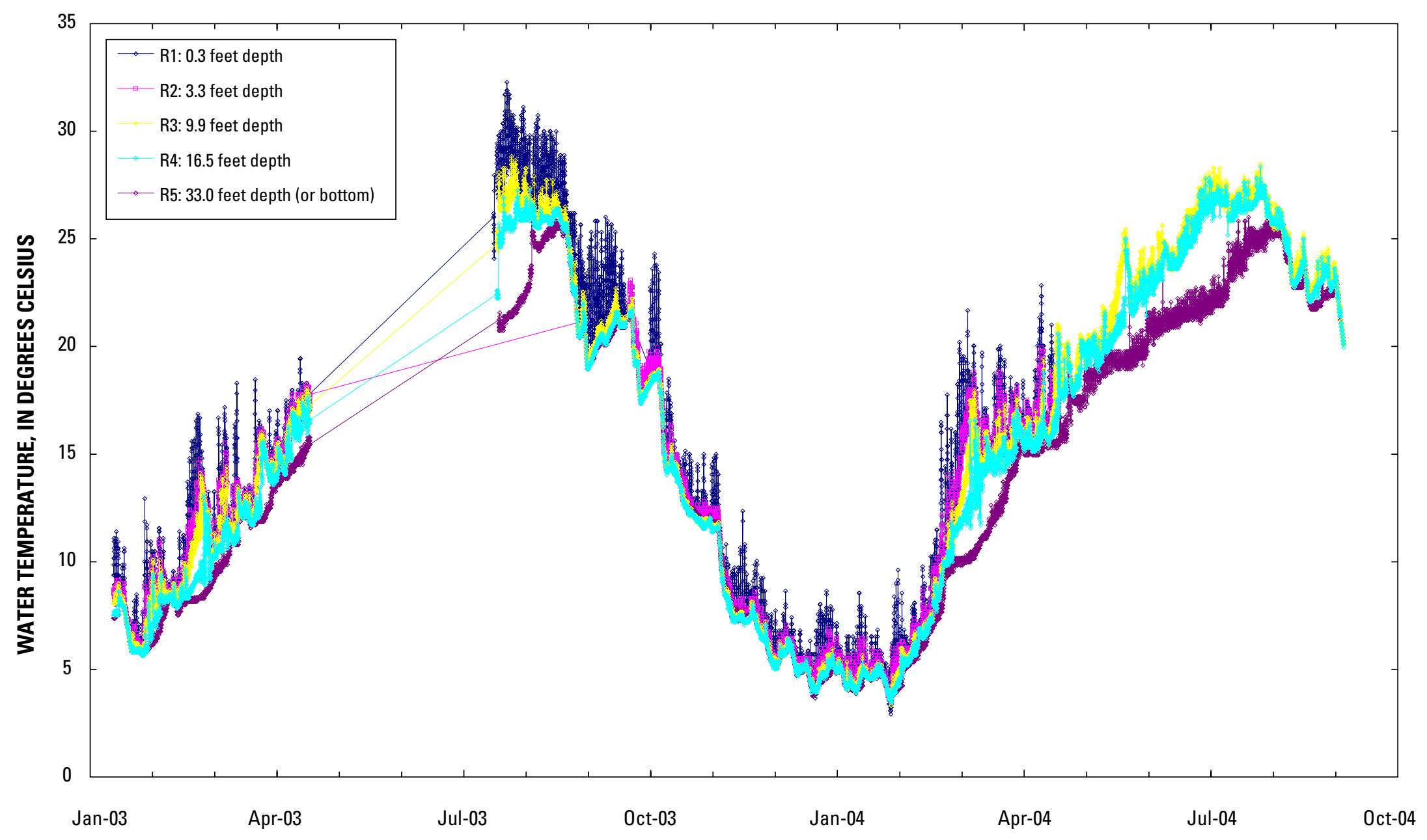

Figure 17. Average hourly water temperature at various depths in Sand Hollow Reservoir, Utah, 2003-04. 


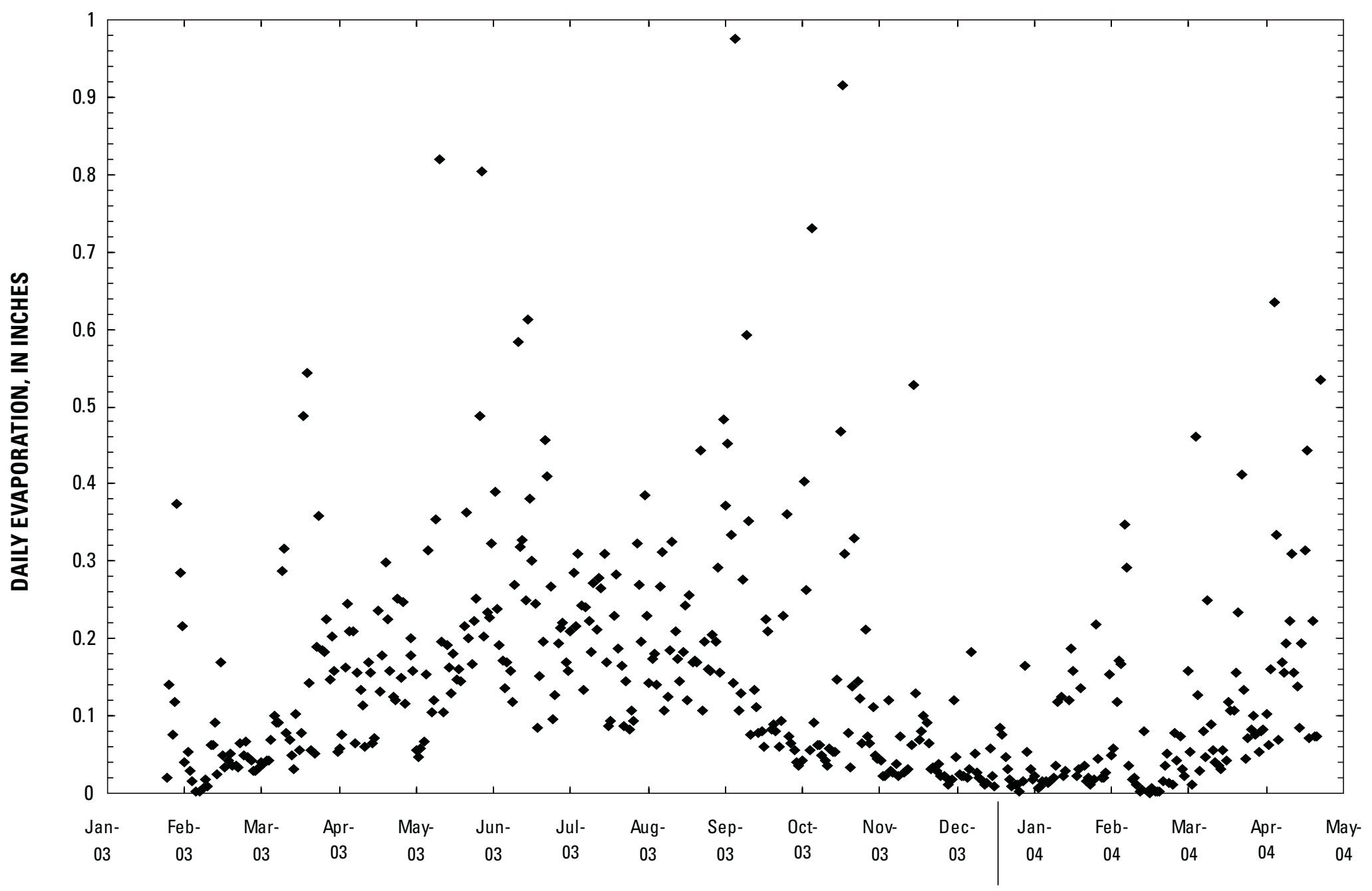

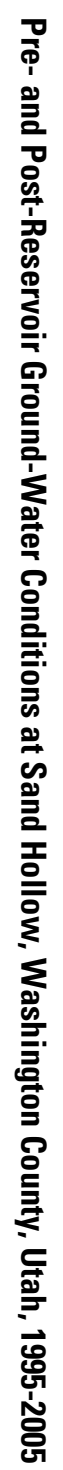

Figure 18. Daily evaporation calculated with the turbulent-transfer method for Sand Hollow Reservoir, Utah, 2003-04. 
A comparison of annual evaporation estimates are shown in figure 19. Assuming that about 8 percent of annual evaporation occurs during the winter months (December through February), the 9-month corrected average annual pan-evaporation rate can be extrapolated to an estimated annual average evaporation rate of about 65 in. per year. Annual Jensen-Haise evaporation ranged from 55.3 to $61.2 \mathrm{in}$. with an average of $59.8 \mathrm{in}$. for 19992003. A detailed evaporation study made using the energy-budget method was done from rafts in Lake Mead, and about 72-84 in. of annual evaporation was measured (Guy DeMeo, U.S. Geological Survey, oral commun., 2004). Lake Mead is at a lower altitude and has a warmer climate than Sand Hollow and thus would be expected to have more evaporation. By estimating evaporation for the missing month of January 2003 as 1.5 in., the annual 2003 turbulent-transfer method evaporation is $54.8 \mathrm{in}$. This is 10 percent less than the annual evaporation calculated with the Jensen-Haise method for 2003. The difference could be the result of the roughness length used in the turbulent-transfer calculation.

Annual Penman evaporation for St. George, Utah, for 1999 and 2003 (72.87 and 67.59 in., respectively) is greater than evaporation estimates from the long-term average (1869-1993) corrected pan evaporation (65 in., with estimates of the winter months), the 1999-2003 average annual Jensen-Haise evaporation (59.8 in.), and the 2003 annual turbulent-transfer egmvaporation (54.8 in.). These annual Penman evaporation estimates are almost equal to evaporation measured at Lake Mead with energy-budget methods, which indicates that it is probably overestimating evaporation (Guy DeMeo, U.S. Geological Survey, oral commun., 2004). The overestimation of evaporation at Sand Hollow Reservoir made using the Penman equation with St. George data is possibly because the climate is slightly different between the two sites. To use the Penman method at Sand Hollow Reservoir, a net radiometer and soil-temperature and heat-flux sensors would need to be added to the Sand Hollow weather station.

Regarding the applicability of the other methods for estimating evaporation from Sand Hollow Reservoir, the turbulent-transfer method estimates evaporation over daily to weekly time periods more accurately than the other methods, but requires more climate variables (including reservoir water temperatures) and is dependent upon the selection of an appropriate roughness coefficient. The corrected St. George pan evaporation rates are considered accurate for Sand Hollow, but have not been calculated since 1993 and do not include winter

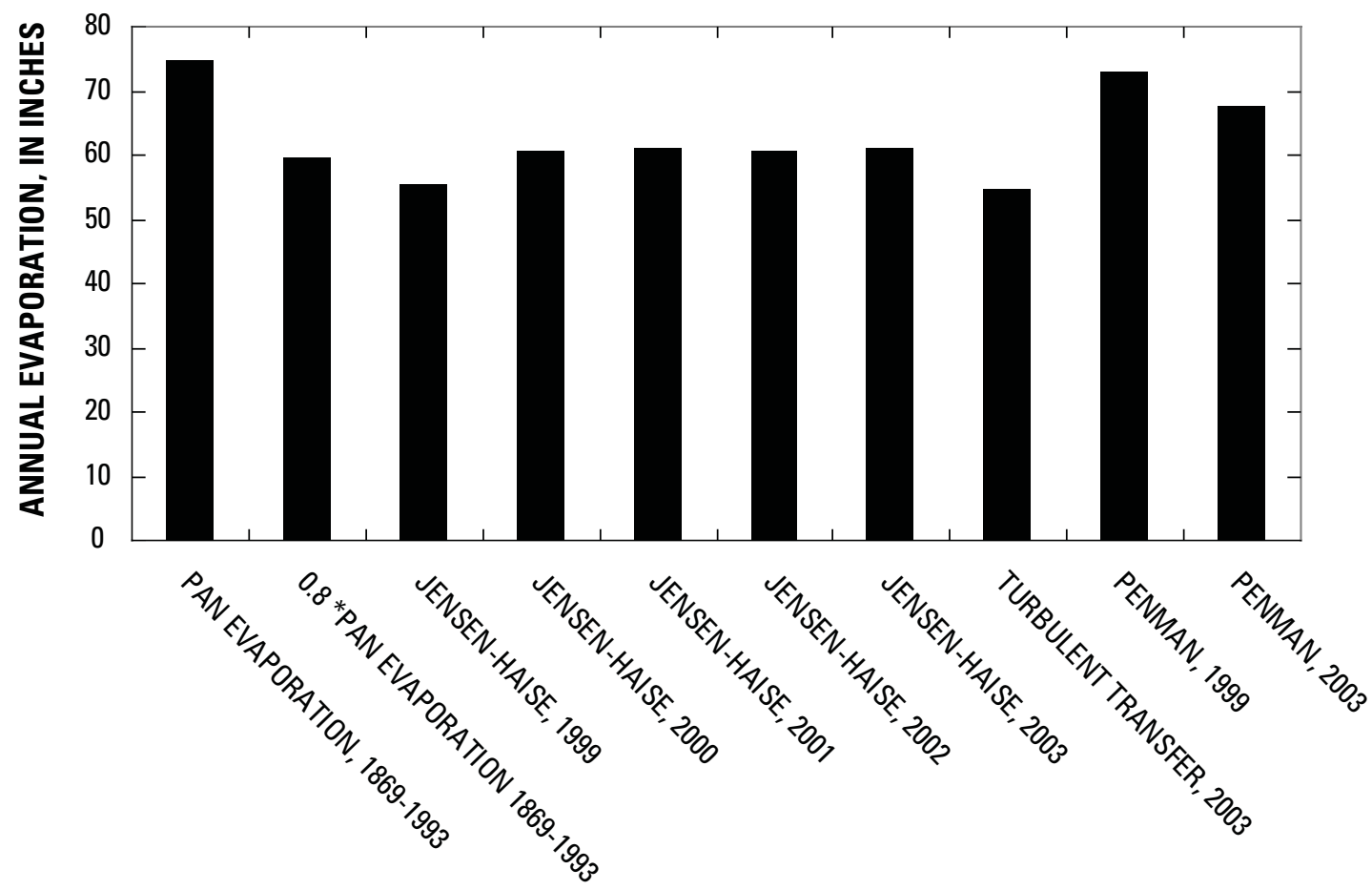

Figure 19. Comparison of average annual estimated evaporation rates for Sand Hollow Reservoir, Utah. 
measurements. Therefore, the Jensen-Haise method is considered the most cost-effective and suitable for estimating evaporative losses from Sand Hollow Reservoir.

The total estimated amount of evaporation from Sand Hollow Reservoir from March 2002 to September 2004 is 5,850 acre- $\mathrm{ft}$ (table 6). This is based on evaporation rates estimated using the Jensen-Haise method, as well as reservoir-surface altitudes and stagesurface-area relations for the reservoir (Washington County Water Conservancy District, written commun., 2004). Since the initial filling of the reservoir, monthly evaporation amounts ranged from about 20 acre-ft during November 2003 to 650 acre-ft during June 2004, depending both on the reservoir surface area and the evaporation rate.

\section{Artificial Recharge Estimates}

Since the initial filling of Sand Hollow Reservoir in March 2002 until September 2004, its altitude has varied from 2,993 to 3,027 ft (fig. 20), with an estimated surface area ranging from 140 to 780 acres (Washington County Water Conservancy District, written commun.,
2004). Monthly estimated recharge was calculated by using equation 2 . On the basis of reported surface-water inflows, outflows, and changes in reservoir storage (Washington County Water Conservancy District, written commun., 2004), monthly recharge ranged from about 3,500 acre-ft during March 2002 down to about 190 acre$\mathrm{ft}$ during October 2003 (table 7, fig. 20). On the basis of total net surface-water inflows into the reservoir of about 46,000 acre-ft from March 2002 through August 2004, evaporative losses of about 6,000 acre-ft, and the approximately 12,000 acre-ft of surface-water in the reservoir as of August 30, 2004, the total estimated artificial recharge to the underlying Navajo aquifer during this 30 -month period is estimated to be about 28,000 acre-ft.

Artificial recharge rates beneath Sand Hollow reservoir decreased from $0.44 \mathrm{ft} / \mathrm{d}$ during the first month down to about $0.03 \mathrm{ft} / \mathrm{d}$ during the latter part of 2003 . The anomalously large amounts of recharge during the first 3 months were caused by the filling of the previously dry vadose zone. Excluding the initial 3-month wetting-up of the vadose zone, the average recharge rate and hydraulic conductivity was about $0.06 \mathrm{ft} / \mathrm{d}$.

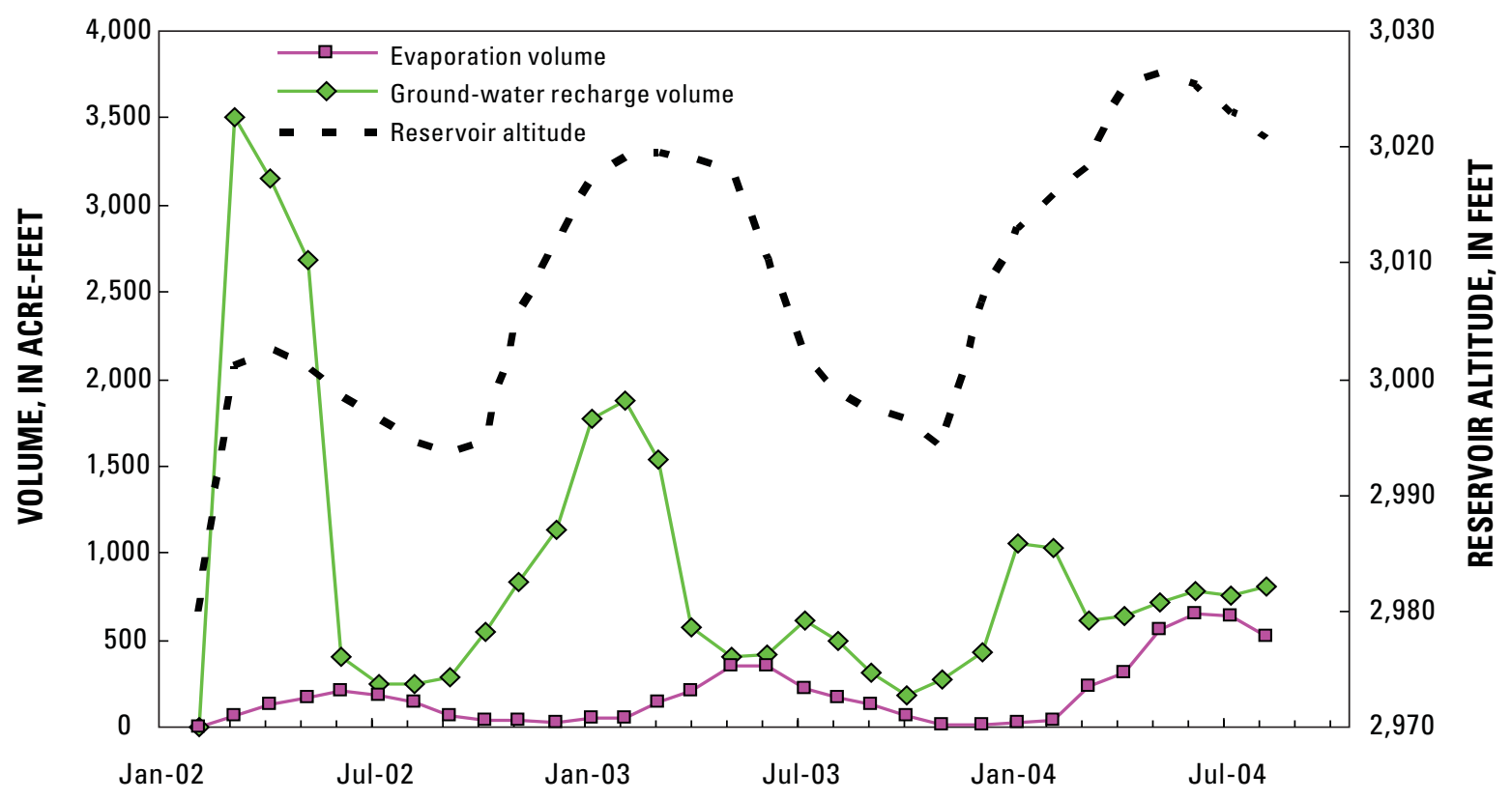

Figure 20. Monthly estimated evaporation, ground-water recharge, and reservoir altitude, Sand Hollow Reservoir, Utah, 2002-04. 
For the measured range in water temperature of 5.0 to $24.0^{\circ} \mathrm{C}$ at a depth of about $33 \mathrm{ft}$ in Sand Hollow Reservoir, dynamic viscosities range from 0.92 to 1.52 centipoise $\left(6.22 \times 10^{-4}\right.$ to $1.02 \times 10^{-3} \mathrm{lb} / \mathrm{ft}$-sec $)$. In equation 4 , these dynamic viscosity values indicate that actual recharge rates and hydraulic conductivity values beneath the reservoir were as much as 8 percent lower during the summer months and as much as 36 percent higher during the winter months than if the reservoir water temperature remained constant at $20.0^{\circ} \mathrm{C}$. Average monthly viscosity-corrected hydraulic conductivity ranges from 0.02 to $0.57 \mathrm{ft} / \mathrm{d}$ were calculated by using equations 4 and 5 (table 7, fig. 21). These are at the low end of the range of laboratory core saturated hydraulicconductivity values reported by Heilweil and others (2004), which generally represent matrix (rather than fracture) permeability.

Monthly total recharge quantities (fig. 20) and viscosity-corrected hydraulic-conductivity values (fig. 21) generally mimic reservoir altitudes because a higher reservoir stage results in both larger wetted areas and larger vertical hydraulic gradients. However, viscositycorrected hydraulic conductivity dropped off in the spring of all three years (2002-04) when the reservoir altitude was still high. Similarly, despite the higher reservoir stage each consecutive year, the peak monthly total recharge was almost 50 percent lower in each of the three consecutive years (fig. 20). Possible causes for these seasonal and longer-term decreases are siltation, biofilm formation, or gas clogging along the bottom of the reservoir. A yearly silt layer may form as suspended sediments in the new water brought into the reservoir each winter and spring settle out on the floor of the reservoir. These low-permeability fine-grained sediments would likely reduce vertical hydraulic conductivity and artificial recharge. Seasonal biofilm development has been observed beneath the reservoir, corresponding to increases in reservoir water temperature. This may also reduce infiltration into the material beneath the reservoir. Finally, trapped gas bubbles in the sediments directly beneath the reservoir may expand seasonally with warmer spring and summer water temperatures, causing increased gas-clogging and permeability reduction.

Excluding the very large initial recharge rates during the wetting-up period, the average recharge rate of $0.08 \mathrm{ft} / \mathrm{d}$ beneath Sand Hollow Reservoir during the first year of operation is less than one-half of the recharge rate of $0.18 \mathrm{ft} / \mathrm{d}$ reported during the 10 -month infiltration

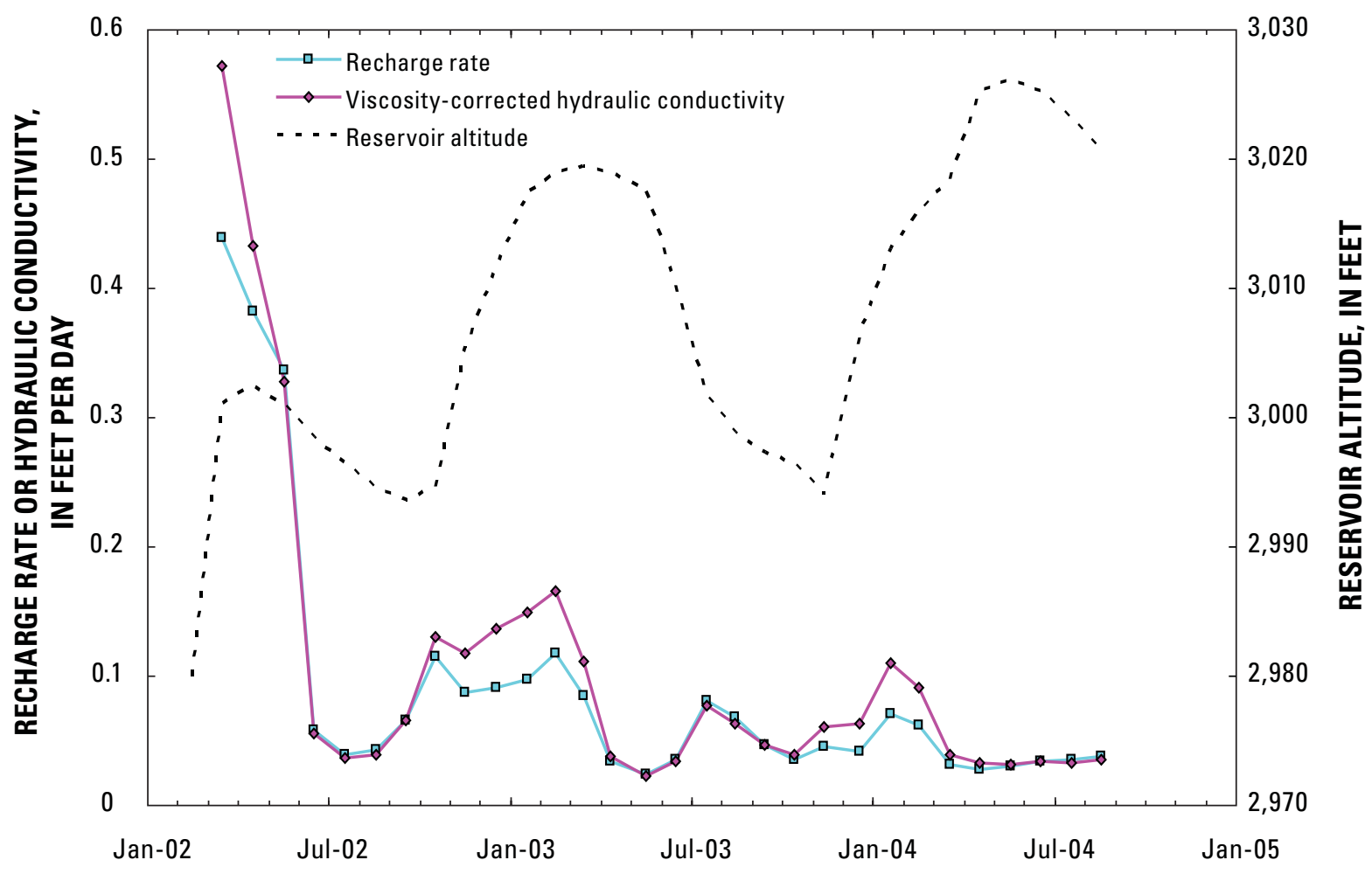

Figure 21. Monthly artificial recharge rate, viscosity-corrected hydraulic conductivity, and reservoir altitude, Sand Hollow Reservoir, Utah, $2002-04$. 
pond experiment (Heilweil and others, 2004) located at the IFP 1 site (map number 12 in fig. 3 , table 1). These lower recharge rates may be caused by (1) lower hydraulic gradients after the ground-water table connected with the surface-water reservoir, (2) finergrained surficial soils beneath the lower part of the reservoir, compared to the IFP 1 site (Heilweil and Solomon, in press, fig. 2), (3) more biofilm development beneath the larger reservoir because of higher nutrient concentrations in the surface-water sources compared to the ground water used for the infiltration pond experiment, (4) the deposition of more silt along the bottom of the reservoir, which is filled with Virgin River water containing higher suspended sediments than the ground water used during the infiltration pond experiment, or (5) larger amounts of trapped air beneath the reservoir, causing more gas-clogging and permeability reduction.

\section{SUMMARY}

Sand Hollow Reservoir was constructed in 2002 to provide both surface-water storage and artificial recharge to the underlying Navajo aquifer in Washington County, Utah. The U.S. Geological Survey conducted a study in cooperation with the Washington County Water Conservancy District, Bureau of Reclamation, and the University of Utah Department of Geology and Geophysics to document baseline ground-water conditions at Sand Hollow prior to the operation of the surface-water reservoir to evaluate changes in groundwater conditions caused by the reservoir.

Prior to the filling of Sand Hollow Reservoir in March 2002, water-level fluctuations at observation wells generally were less than $10 \mathrm{ft}$ except in the immediate vicinity of production wells. The pre-reservoir direction of ground-water flow was predominantly north toward where it discharges into the Virgin River. Since March 2002, water levels in the immediate vicinity of Sand Hollow Reservoir have risen by as much as $80 \mathrm{ft}$ and ground water is currently moving away from the reservoir in all directions.

Before the reservoir was constructed, age dating of ground water in Sand Hollow basin by using ${ }^{3} \mathrm{H} /{ }^{3} \mathrm{He}$, chlorofluorocarbons, and ${ }^{14} \mathrm{C}$ indicated that shallow ground water in Sand Hollow had entered the aquifer recently at some locations. Water deeper within the aquifer may be as old as 8,500 years. The dissolvedsolids concentration of pre-reservoir ground water within Sand Hollow was less than $400 \mathrm{mg} / \mathrm{L}$. Measured natural concentrations of nutrients including nitrate, ammonia, and phosphorus were generally less than current EPA drinking-water standards. Water from seven wells had pre-reservoir arsenic concentrations exceeding the EPA standard of $10 \mu \mathrm{g} / \mathrm{L}$, with values ranging between 12 and $55 \mu \mathrm{g} / \mathrm{L}$. Ratios of stable isotopes in pre-reservoir ground water had mean ground-water values of -86 permil for $\delta^{2} \mathrm{H}$ and -11.1 permil for $\delta^{18} \mathrm{O}$, which is similar to mean precipitation values and indicates that local precipitation is the primary source of natural recharge to the aquifer.

Tracers of artificial recharge include specific conductance, $\mathrm{Cl}: \mathrm{Br}$ ratios, and total dissolved-gas pressures. Specific-conductance values of ground water have risen at observation wells close to the reservoir, approaching reservoir values, which average about 800 $\mu \mathrm{S} / \mathrm{cm} . \mathrm{Cl}: \mathrm{Br}$ ratios of ground water have increased in some wells near the reservoir but remain well below the values (as high as 5,000) measured in reservoir water, possibly buffered by the flushing of previously accumulated vadose-zone salts with relatively low $\mathrm{Cl}: \mathrm{Br}$ ratios. The flushing of these naturally occurring vadosezone salts, however, is not generally affecting water quality within the aquifer, likely because of its large saturated thickness. In-situ total dissolved-gas pressure in ground water near the reservoir showed large increases since the filling of the reservoir, caused by the combination of dissolution of entrapped air bubbles (excess air) and increased hydrostatic head associated with the rapidly rising water table. Total dissolved-gas pressure has risen from about 1 to at least 3 atmospheres in shallow observation wells adjacent to the reservoir. This indicates that gas clogging associated with trapped air may be reducing the permeability of the sandstone in the vicinity of the reservoir.

Arsenic concentrations have risen in water at three shallow observation wells within Sand Hollow, but no trends are apparent yet in arsenic concentrations in ground water from deeper within the aquifer. In addition to the wells containing water with high natural arsenic concentrations (prior to the reservoir filling), 10 other wells have water with post-reservoir arsenic concentrations exceeding the EPA standard, with values ranging from 10 to $90 \mu \mathrm{g} / \mathrm{L}$. On the basis of the persistence of high arsenic concentrations at the North Dam 3A observation well, increased arsenic concentration is likely caused by changes in $\mathrm{pH}$ associated with the reservoir, rather than flushing of vadose-zone salts or from recharging reservoir water (with arsenic concentrations generally less than $3 \mu \mathrm{g} / \mathrm{L}$ ). 
To estimate artificial recharge beneath Sand Hollow Reservoir, a water-budget approach was used. Components of the water budget include surface-water inflows and outflows to and from the reservoir, evaporation, and changes in surface-water storage. Evaporation from the surface of Sand Hollow Reservoir was estimated with a variety of techniques, including physical measurements (pan-evaporation data from nearby St. George, Utah), estimates based on meteorological data (Penman and Jensen-Haise methods), and estimates based on reservoir watertemperature measurements (turbulent-transfer method). Using meteorological data from the weather station at Sand Hollow, the Jensen-Haise method provides the best combination of cost and accuracy. Estimated evaporation rates using this method range from 55 to 61 in. per year, resulting in a total estimated evaporative loss of about 6,000 acre-ft of water from March 2002 to September 2004 from Sand Hollow Reservoir. Based on total net surface-water inflows to the reservoir of about 46,000 acre-ft during this period and the 12,000 acre-ft of surface-water in the reservoir as of August 30, 2002, the total estimated artificial recharge to the underlying Navajo aquifer during this 30 -month period is estimated to be about 28,000 acre-ft. Rates of artificial recharge have ranged from about 0.02 to $0.44 \mathrm{ft} /$ day, with an average rate (excluding the initial 3-month wetting period) of about $0.06 \mathrm{ft} / \mathrm{d}$. This is about one-third of the expected rates based on a previous 10-month long infiltration pond experiment. Possible causes for this are lower hydraulic gradients once the ground-water table connected with the surface-water reservoir, lowerpermeability surficial soils, siltation and/or bioclogging, or gas clogging caused by trapped air. The general decline in recharge rates during the 3 -year period since initial filling is a typical pattern observed at most artificial recharge facilities.

\section{REFERENCES CITED}

Beitler, B., Parry, W.T., and Chan, M.A., 2005, Fingerprints of fluid flow: Chemical diagenetic history of the Jurassic Navajo Sandstone, southern Utah: Journal of Sedimentary Research, v. 75, p. 545-559.

Brutsaert, W., 1982, Evaporation into the atmosphere: Hingham, Mass., D. Rreidel, 299 p.

Budding, K.E., and Sommer, S.N., 1986, Lowtemperature geothermal assessment of the Santa Clara and Virgin River Valleys, Washington
County, Utah: Utah Department of Natural Resources Special Studies No. 67, 34 p.

Clarke, W.B., Jenkins, W.J. and Top, Z., 1976, Determination of tritium by mass spectrometric measurements of $3 \mathrm{He}$ : International Journal of Applied Radiation Isotopes, v. 27, p. 515-522.

Coplen, T.B., Plummer, L.N., and Mullin, A., 1996, Collection, processing, and analysis of carbon isotope samples: U.S. Geological Survey National Water-Quality Laboratory Technical Memorandum 96.05, $10 \mathrm{p}$.

Cordova, R.M., 1978, Ground-water conditions in the Navajo Sandstone in the central Virgin River basin, Utah: State of Utah Department of Natural Resources Technical Publication No. 61, 66 p.

Craig, H., 1961, Isotopic variations on meteoric waters: Science, 133, p. 1702-1703.

Davis, S.N., Whittemore, D.O., and Fabryka-Martin, J., 1998, Uses of chloride/bromide ratios in studies of potable water: Ground Water, v. 36, no. 2, p. 338350.

Friedman, I., Smith, G.I., Gleason, J.D., Warden, A., and Harris, J.M., 1992, Stable isotope composition of waters in southeastern California: 1. Modern Precipitation, Journal of Geophysical Research, v. 97, no. D5, p. 5795-5812.

Heilweil, V.M., 2003, Recharge to the Navajo Sandstone aquifer of southwestern Utah: Salt Lake City, University of Utah, Ph.D. Dissertation, 278 p.

Heilweil, V.M., Freethey, G.W., Stolp, B.J., Wilkowske, C.D., and Wilberg, D.E., 2000, Geohydrology and numerical simulation of ground-water flow in the central Virgin River basin of Iron and Washington Counties, Utah: State of Utah Department of Natural Resources Technical Publication No. 116, 139 p.

Heilweil, V.M., and Solomon, D.K., in press, Borehole environmental tracers for evaluating infiltration and recharge to desert bedrock, Vadose Zone Journal.

Heilweil, V.M., and Solomon, D.K., 2004, Millimeter- to kilometer-scale variations in vadose-zone bedrock solutes: Implications for estimating recharge in arid settings, in Hogan, J.F., Phillips, F.M., and Scanlon, B.R., eds., Groundwater Recharge in a Desert Environment: The Southwestern United States, Water Science and Applications Series, v. 9, American Geophysical Union, Washington, D.C., p. 49-67.

Heilweil, V.M., Solomon, D.K., Gardner, P.M., in press, Infiltration and recharge at Sand Hollow, an upland bedrock basin in southwestern Utah, in Investigations of Focused Ground-Water Recharge 
Processes in the Southwestern United States, U.S. Geological Survey Professional Paper.

Heilweil, V.M., Solomon, D.K., Perkins, K.S., and Ellett, K.M., 2004, Gas-partitioning tracer test to quantify trapped gas during recharge: Ground Water, v. 42, no. 4, p. 589-600.

Herbert, L.R., 1995, Seepage study of the Virgin River from Ash Creek to Harrisburg Dome, Washington County, Utah: State of Utah Department of Natural Resources Technical Publication No. 106, 8 p.

Hurlow, H.A., 1998, The geology of the central Virgin River basin, southwestern Utah, and its relation to ground-water conditions: State of Utah Water Resources Bulletin 26, 53 p.

International Atomic Energy Agency, 2002, Global Network for Isotopes in Precipitation: accessed July 23, 2002, at URL http://isohis.iaea.org/

Kalin, R.M., 2000, Radiocarbon dating of groundwater systems: in Cook, P., Herczeg, A.L., eds., Environmental Tracers in Subsurface Hydrology: Kluwer Academic Publishers, p. 349-377.

Kimball, B.A., 1992, Geochemical indicators used to determine source of saline water in Mesozoic aquifers, Montezuma Canyon area, Utah, in Subitzky, S., ed., Selected Papers in the Hydrologic Sciences, 1988-1992: U.S. Geological Survey Water-Supply Paper 2340, p. 89-106.

McGuinness, J.L., and Bordne, E.F., 1971, A comparison of lysimeter-derived potential evapotranspiration with computed values: U.S. Department of Agriculture Technical Bulletin 1472, Agricultural Research Service, Washington D.C., 71 p.

Naftz, D.L., Peterman, Z.E., and Spangler, L.E., 1997, Using $87 \mathrm{Sr}$ values to identify sources of salinity to a freshwater aquifer, greater Aneth Oil Field, Utah, USA: Chemical Geology, v. 141, p. 195-209.

Pearson, F.J., and Hanshaw, B.B., 1970, Sources of dissolved carbonate species in groundwater and their effects on carbon-14 dating, in Isotope Hydrology 1970: IAEA Symposium 129, March 1970, Vienna, p. 271-286.

Press, F. and Siever, R., 1978, Earth, 2d ed.: San Francisco, Calif., W.H. Freeman and Co., 649 p.

Robson, S.G., and Banta, E.R., 1995, Ground-water atlas of the United States, Segment 2: Arizona, Colorado, New Mexico, Utah, U.S. Geological Survey Hydrologic Investigations Atlas 730-C., 32 p.

Scudlark, J.R., and Church, T.M., 1988, Atmospheric deposition of arsenic and association with acid precipitation: Atmospheric Environment ATENBP, v. 22, no. 5, p. 937-943.
Sheldon, A., 2002, Diffusion of radiogenic helium in shallow ground water: Implications for crustal degassing, Salt Lake City, University of Utah, Ph.D. dissertation, $185 \mathrm{p}$.

Solomon and Heilweil, 2004, Trapped gases beneath a recently completed reservoir: Using artificial recharge as an analogue to natural processes, Geological Society of America Annual Meeting Abstracts with Programs, v. 36, no. 5, p. 470.

Stute, M., and Schlosser, P., 2001, Atmospheric noble gases, in Cook, P., Herczeg, A.L., eds., Environmental Tracers in Subsurface Hydrology: Boston, Mass., Kluwer Academic Publishers, p. 349-377.

Thorstenson, D.C., Weeks, E.P., Haas, H., Busenberg, E., Plummer, L.N., and Peters, C.A., 1998, Chemistry of unsaturated zone gases sampled in open boreholes at the crest of Yucca Mountain, Nevada: Data and basic concepts of chemical and physical processes in the mountain: Water Resources Research v. 34, no. 6, p. 1507-1529.

U.S. Census Bureau, 1992, 1990 Census of population characteristics: U.S. Department of Commerce, accessed June 14, 2002, at http://www.census.gov/

U.S. Census Bureau, 2003, 2000 Census of population and housing: U.S. Department of Commerce, accessed June 14, 2002, at http://factfinder.census.gov/

U.S. Department of Agriculture, 1999, Image Processing Workbench (IPW), ARS-USGS Version 2, ASR Technical Bulletin 99-1, Northwest Watershed Research Center, accessed June 15, 2004, at http:// cirque.nwrc.ars.usda.gov/ ipw/

U.S. Environmental Protection Agency, 2001, EPA to implement $10 \mathrm{ppb}$ standard for arsenic in drinking water: EPA Fact Sheet 815-F-01-010, 2001.

Warnaka, K., and Pochop, L., 1988, Analyses of equations for free water evaporation estimates: Water Resources Research v. 24, no. 7, p. 979-984.

Welch, A.H., and Preissler, A.M., 1986, Aqueous geochemistry of the Bradys Hot Springs geothermal area, Churchill County, Nevada, in Selected Papers in the Hydrologic Sciences, U.S. Geological Survey Water-Supply Paper 2290, p. 17-36.

Welch, A.H., Westjjohn, D.B., Helsel, D.R., and Wanty, R.B., 2000, Arsenic in ground water of the United States: Occurrence and geochemistry: Ground Water, v. 38, no. 4, p. 589-604.

Western Region Climate Center, 2004, Monthly and annual precipitation at St. George, Utah (Station 
427516), accessed January 28, 2005, at http://www.wrcc.dri.edu/

Wilde, F.D., Radtke, D.B., Gibs, J., and Iwatsubo, R.T., eds, 1998, National field manual for the collection of water-quality data: U.S. Geological Survey Techniques of Water-Resources Investigations book 9, chap. A4, 103 p.

Wilkowske, C.D., Heilweil, V.M., and Wilberg, D.E., 1998, Selected hydrologic data for the central Virgin River basin area, Washington and Iron Counties, Utah, 1915-97: U.S. Geological Survey Open-File Report 98-389, 53 p.

Winter, T.C., Rosenberry, D.O., and Sturrock, A.M., 1995, Evaluation of 11 equations for determining evaporation from a small lake in the north central United States: Water Resources Research v. 31, no. 4, p. 983-993. 
Table 1. Records of selected wells and boreholes in Sand Hollow, Utah

[Map number: Refer to figure 3; Primary use of site: W, withdrawal; O, observation. Depth of well: A, abandoned. Casing finish: F, sand with perforations; S, screen; X, open hole. Water level: Measured by the U.S. Geological Survey except where noted; L, reported in drillers' logs; E, estimated; Other data available: $\mathrm{W}$, water-level measurements in table 2 ; $\mathrm{C}$, general chemical analyses in table 3; I, chemical analyses of isotopes, chlorofluorocarbons, and/or tritium in table 4. All wells are within the Navajo Sandstone; —, no data available]

\begin{tabular}{|c|c|c|c|c|c|c|c|}
\hline \multirow[b]{2}{*}{$\begin{array}{c}\text { Map } \\
\text { number }\end{array}$} & \multirow[b]{2}{*}{ Well location } & \multirow[b]{2}{*}{ Well name } & Latitude & Longitude & \multirow{2}{*}{$\begin{array}{l}\text { Altitude } \\
\text { of } \\
\text { land } \\
\text { surface } \\
\text { (feet) }\end{array}$} & \multirow[b]{2}{*}{$\begin{array}{c}\text { Year } \\
\text { drilled }\end{array}$} & \multirow[b]{2}{*}{$\begin{array}{l}\text { Primary } \\
\text { use of site }\end{array}$} \\
\hline & & & \multicolumn{2}{|c|}{ (degree/minute/second) } & & & \\
\hline $1 \mathrm{a}$ & $(\mathrm{C}-42-13) 18 \mathrm{bcb}-2$ & Wayne Wilson (original) & 370812 & 1132148 & 2,960 & 1959 & W \\
\hline $1 b$ & (C-42-13)18bcb-2 & Well 1 (Wayne Wilson redrilled) & 370812 & 1132148 & 2,960 & 2002 & $\mathrm{~W}$ \\
\hline
\end{tabular}

2 (C-42-13)19cdb-1

3 (C-42-13)19dcb-1
WD 12 (Slope 2)

Well 2 (east side of reservoir)

\section{4}

370651
1132135
1132117

$\begin{array}{lll}3,079 & 1999 & \text { O } \\ 3,145 & 2002 & \text { W }\end{array}$

5 (C-42-13)30bcd-1

6 (C-42-13)30bdc-1

7 (C-42-14)13aad-1

8 (C-42-14)13acd-2

9 (C-42-14)13cda-1

10 (C-42-14)13cdd-1

11 (C-42-14)13dca-1

12 (C-42-14)13dca-2

13 (C-42-14)13dca-11

14 (C-42-14)13dca-12

15 (C-42-14)13dca-13

16 (C-42-14)13dca-14

17 (C-42-14)13dca-15

18 (C-42-14)13dca-17

19 (C-42-14)13dca-18

20 (C-42-14)13dca-19

21 (C-42-14)13dca-20

22 (C-42-14)13dca-21

23 (C-42-14)13dca-22

24 (C-42-14)13dca-23

25 (C-42-14)13dca-24

26 (C-42-14)13dca-29

27 (C-42-14)13dcd-1

28 (C-42-14)13dcd-2

29 (C-42-14)13ddc-1

30 (C-42-14)13ddc-2

31 (C-42-14)13ddd-1

32 (C-42-14)14aad-1
Ridge 1

WD 10 (Island)

Well 4 (Sky Ranch 2)

Dale Wilson

WD 4

WD 6 (Slickrock)

Well 8 (west side North Dam)

WD 2

IFP 1

IFP 1 (Port 1)

IFP 1 (Port 2)

IFP 1 (Port 3)

IFP 1 (Port 4)

IFP 1 (Port 5)

IFP 5 Shallow

IFP 5 Medium

IFP 5 Deep

IFP 6 Shallow

IFP 6 Medium

IFP 6 Deep

IFP 7 Shallow

IFP 7 Deep

${ }^{1}$ IFP 2

Wash 1

North Dam 3A

Well 9 (east side of North Dam)

North Dam Drain

WD 1

WD RJ

$\begin{array}{lllll}370647 & 1132054 & 3,380 & 1999 & \mathrm{O} \\ 370628 & 1132141 & 3,060 & 2001 & \mathrm{O} \\ 370622 & 1132133 & 3,070 & 1994 & \mathrm{~W} \\ 370821 & 1132201 & 2,940 & 1985 & \mathrm{~W} \\ 370806 & 1132222 & 2,962 & 1995 & \mathrm{O} \\ 370753 & 1132231 & 3,004 & 2001 & \mathrm{O} \\ 370742 & 1132236 & 3,050 & 2001 & \mathrm{~W} \\ 370746 & 1132223 & 2,988 & 1995 & \mathrm{O} \\ 370745 & 1132220 & 2,976 & 1999 & \mathrm{O} \\ 370745 & 1132220 & 2,976 & 1999 & \mathrm{O} \\ 370745 & 1132220 & 2,976 & 1999 & \mathrm{O} \\ 370745 & 1132220 & 2,976 & 1999 & \mathrm{O} \\ 370745 & 1132220 & 2,976 & 1999 & \mathrm{O} \\ 370745 & 1132220 & 2,976 & 1999 & \mathrm{O} \\ 370745 & 1132220 & 2,977 & 2000 & \mathrm{O} \\ 370745 & 1132220 & 2,977 & 2000 & \mathrm{O} \\ 370745 & 1132220 & 2,977 & 2000 & \mathrm{O} \\ 370745 & 1132220 & 2,977 & 2000 & \mathrm{O} \\ 370745 & 1132220 & 2,977 & 2000 & \mathrm{O} \\ 370745 & 1132220 & 2,977 & 2000 & \mathrm{O} \\ 370745 & 1132220 & 2,980 & 2000 & \mathrm{O} \\ 370745 & 1132220 & 2,980 & 2000 & \mathrm{O} \\ 370745 & 1132221 & 2,977 & 1999 & \mathrm{O} \\ 370737 & 1132220 & 2,972 & 1999 & \mathrm{O} \\ 370738 & 1132217 & 2,970 & 2001 & \mathrm{O} \\ 370738 & 1132209 & 2,970 & 2000 & \mathrm{~W} \\ 370738 & 1132215 & 2,970 & 2001 & \mathrm{~W} \\ 370738 & 1132205 & 2,998 & 1995 & \mathrm{O} \\ 370822 & 1132315 & 2,952 & 1995 & \mathrm{O}\end{array}$


Table 1. Records of selected wells and boreholes in Sand Hollow, Utah—Continued

\begin{tabular}{|c|c|c|c|c|c|c|c|c|}
\hline \multirow[b]{2}{*}{$\begin{array}{c}\text { Map } \\
\text { number }\end{array}$} & \multirow{2}{*}{$\begin{array}{c}\text { Depth of } \\
\text { well } \\
\text { (feet) }\end{array}$} & \multicolumn{3}{|c|}{ Casing } & \multicolumn{2}{|c|}{ Water level } & \multirow{2}{*}{$\begin{array}{c}\text { Depth of } \\
\text { openings } \\
\text { below water } \\
\text { table } \\
\text { (feet) }\end{array}$} & \multirow[b]{2}{*}{$\begin{array}{l}\text { Other data } \\
\text { available }\end{array}$} \\
\hline & & $\begin{array}{c}\text { Diameter } \\
\text { (inches) }\end{array}$ & $\begin{array}{c}\text { Bottom } \\
\text { (feet) }\end{array}$ & $\begin{array}{l}\text { Finish } \\
\text { (feet) }\end{array}$ & $\begin{array}{l}\text { Below land } \\
\text { surface } \\
\text { (feet) }\end{array}$ & $\begin{array}{c}\text { Date } \\
\text { measured }\end{array}$ & & \\
\hline $1 \mathrm{a}$ & 194 & 14 & 17 & X 17-194 & 67.63 & $01 / 04 / 2000$ & 0 to 126 & $\mathrm{C}, \mathrm{I}$ \\
\hline \multirow[t]{5}{*}{$1 b$} & 1,000 & 24 & 1,000 & S $120-340$ & - & - & 52 to 272 & $\mathrm{C}, \mathrm{I}$ \\
\hline & & & & S $380-500$ & - & - & 312 to 432 & - \\
\hline & & & & S 540-660 & - & - & 472 to 592 & - \\
\hline & & & & S 700-820 & - & - & 632 to 752 & - \\
\hline & & & & S $860-1,000$ & - & - & 792 to 932 & $\mathrm{C}, \mathrm{I}$ \\
\hline 2 & 164.6 & .75 & 155.5 & F $150.3-155.3$ & 148.78 & 09/04/2001 & 1.5 to 6.5 & W, I \\
\hline \multirow[t]{5}{*}{3} & 900 & 16 & 900 & S $135-295$ & 212.29 & $10 / 07 / 2002$ & 0 to 81 & $\mathrm{C}, \mathrm{I}$ \\
\hline & & & & S $335-415$ & - & - & 123 to 194 & $\mathrm{C}, \mathrm{I}$ \\
\hline & & & & S 455-535 & - & - & 243 to 323 & $\mathrm{C}, \mathrm{I}$ \\
\hline & & & & S 575-655 & - & - & 363 to 443 & $\mathrm{C}, \mathrm{I}$ \\
\hline & & & & S 695-855 & - & - & 483 to 643 & $\mathrm{C}, \mathrm{I}$ \\
\hline 4 & $89 \mathrm{~A}$ & - & - & - & Dry & 05/04/1999 & - & - \\
\hline 5 & 133.8 & 2 & 122 & F 116.8-121.9 & 119.13 & 09/04/2001 & 0 to 2.7 & $\mathrm{C}, \mathrm{I}$ \\
\hline 6 & 590 & 12 & 52 & X 52-590 & 130.68 & 07/17/2001 & 0 to 459 & $\mathrm{C}, \mathrm{I}$ \\
\hline 7 & 200 & 8 & 20 & X 20-200 & 59.40 & 02/17/1996 & 0 to 141 & I \\
\hline 8 & 90 & 1 & 90 & F 80-90 & 60.25 & 09/04/2001 & 20 to 30 & $\mathrm{~W}, \mathrm{C}, \mathrm{I}$ \\
\hline 9 & 96 & 2 & 96 & F 90.8-95.8 & 94.32 & 09/04/2001 & 0 to 5 & $\mathrm{~W}, \mathrm{C}, \mathrm{I}$ \\
\hline \multirow[t]{2}{*}{10} & 624 & 16 & 624 & S 144-504 & ${ }^{2} 91.52$ & $10 / 06 / 2002$ & 52 to 412 & $\mathrm{C}, \mathrm{I}$ \\
\hline & & & & S 544-624 & - & - & 452 to 532 & $\mathrm{C}, \mathrm{I}$ \\
\hline 11 & 104 & 1 & 104 & F 94-104 & 80.70 & 09/04/2001 & 13 to 23 & $\mathrm{~W}, \mathrm{I}$ \\
\hline 12 & 103.5 & - & - & X 0-103.5 & 64.13 & 09/28/1999 & 0 to 39 & $\mathrm{C}, \mathrm{I}$ \\
\hline 13 & 103.5 & .5 & 93.1 & F 92.5-93.0 & 64.14 & 11/28/1999 & 28.5 to 29.0 & I \\
\hline 14 & 103.5 & .5 & 88.6 & F 88.0-88.5 & 64.12 & 11/28/1999 & 24.0 to 24.5 & - \\
\hline 15 & 103.5 & .5 & 82.1 & F 81.5-82.0 & 64.09 & 11/28/1999 & 17.5 to 18.0 & - \\
\hline 16 & 103.5 & .5 & 75.6 & F 75.0-75.5 & 64.02 & 11/28/1999 & 11.0 to 11.5 & I \\
\hline 17 & 103.5 & .5 & 69.1 & F 68.5-69.0 & 64.00 & 11/28/1999 & 4.5 to 5.0 & I \\
\hline 18 & 101 & .75 & 71.2 & F 66.0-71.0 & 65.35 & 07/18/2000 & .7 to 5.7 & I \\
\hline 19 & 101 & .75 & 81.2 & F 76.0-81.0 & 65.27 & $07 / 18 / 2000$ & 10.7 to 15.7 & I \\
\hline 20 & 101 & .75 & 91.2 & F 86.0-91.0 & - & - & 20.7 to 25.7 & I \\
\hline 21 & 103 & .75 & 72.2 & F 67.0-72.0 & 64.79 & $09 / 14 / 2000$ & 2.2 to 7.2 & - \\
\hline 22 & 103 & .75 & 82.2 & F 77.0-82.0 & 64.68 & 09/08/2000 & 12.2 to 17.2 & - \\
\hline 23 & 103 & .75 & 92.2 & F 87.0-92.0 & - & - & 22.2 to 27.2 & - \\
\hline 24 & 79 & .75 & 69.2 & F 64.0-69.0 & 67.80 & 07/19/2000 & 0 to 1.2 & $\mathrm{C}$ \\
\hline 25 & 79 & .75 & 77.2 & F 72.0-77.0 & 66.99 & 06/08/2000 & 4.2 to 9.2 & - \\
\hline 26 & $66 \mathrm{~A}$ & - & - & - & - & - & 0 to 2 & $\mathrm{C}, \mathrm{I}$ \\
\hline 27 & $68 \mathrm{~A}$ & - & - & - & 56.02 & 05/26/1999 & 0 to 12 & $\mathrm{C}, \mathrm{I}$ \\
\hline 28 & 26 & 1 & 25.7 & F $15-25$ & 27.74 & $10 / 08 / 2002$ & 7.3 to 17.3 & $\mathrm{C}, \mathrm{I}$ \\
\hline 29 & 1,210 & 24 & 1,210 & S 104-1140 & $69 \mathrm{~L}$ & 06/30/2000 & 35 to 1,071 & $\mathrm{C}, \mathrm{I}$ \\
\hline 30 & 15 & 48 & 15 & - & - & - & & $\mathrm{C}, \mathrm{I}$ \\
\hline 31 & 110 & 1 & 110 & F $100-110$ & 93.05 & 09/04/2001 & 7 to 17 & $\mathrm{~W}, \mathrm{C}, \mathrm{I}$ \\
\hline 32 & 205 & 1 & 205 & F 195-205 & 56.06 & 09/04/2001 & 139 to 149 & $\mathrm{~W}, \mathrm{C}, \mathrm{I}$ \\
\hline
\end{tabular}


Table 1. Records of selected wells and boreholes in Sand Hollow, Utah-Continued

\begin{tabular}{|c|c|c|c|c|c|c|c|}
\hline \multirow[b]{2}{*}{$\begin{array}{c}\text { Map } \\
\text { number }\end{array}$} & \multirow[b]{2}{*}{ Well location } & \multirow[b]{2}{*}{ Well name } & Latitude & Longitude & \multirow{2}{*}{$\begin{array}{l}\text { Altitude } \\
\text { of } \\
\text { land } \\
\text { surface } \\
\text { (feet) }\end{array}$} & \multirow[b]{2}{*}{$\begin{array}{c}\text { Year } \\
\text { drilled }\end{array}$} & \multirow[b]{2}{*}{$\begin{array}{c}\text { Primary } \\
\text { use of site }\end{array}$} \\
\hline & & & \multicolumn{2}{|c|}{ (deg/min/sec) } & & & \\
\hline 33 & $(\mathrm{C}-42-14) 23 \mathrm{abc}-1$ & WD 5 & 370728 & 1132334 & 2,994 & 1995 & $\mathrm{O}$ \\
\hline 34 & (C-42-14)23daa-1 & WD 3 & 370707 & 1132315 & 3,027 & 1995 & $\mathrm{O}$ \\
\hline 35 & (C-42-14)23dda-1 & Hole N & 370700 & 1132304 & 3,018 & 2001 & $\mathrm{O}$ \\
\hline 36 & (C-42-14)23ddc-1 & WD 11 (West Dam) & 370647 & 1132327 & 3,017 & 2001 & $\mathrm{O}$ \\
\hline 37 & (C-42-14)24bcd-1 & WD 9 (Boat Ramp) & 370723 & 1132256 & 3,066 & 2001 & $\mathrm{O}$ \\
\hline 38 & (C-42-14)24caa-1 & Basin 1 & 370710 & 1132232 & 2,979 & 1999 & $\mathrm{O}$ \\
\hline 39 & (C-42-14)24ddd-1 & Slope 1a & 370650 & 1132201 & 3,029 & 1999 & $\mathrm{O}$ \\
\hline 40 & (C-42-14)24ddd-2 & Slope $1 b$ & 370650 & 1132201 & 3,030 & 1999 & $\mathrm{O}$ \\
\hline 41 & $(\mathrm{C}-42-14) 25 \mathrm{aac}-1$ & Hole Q & 370636 & 1132201 & 3,036 & 2001 & $\mathrm{O}$ \\
\hline 42 & (C-42-14)25abb-1 & Terracor 3 & 370645 & 1132244 & 3,006 & 1970 & $\mathrm{O}$ \\
\hline 43 & (C-42-14)25abb-2 & Hole O & 370645 & 1132244 & 3,006 & 2001 & $\mathrm{O}$ \\
\hline 44 & $(\mathrm{C}-42-14) 25 \mathrm{cdb}-1$ & WD 8 (Sand Dune) & 370607 & 1132247 & 3,075 & 2001 & $\mathrm{O}$ \\
\hline 45 & $(\mathrm{C}-42-14) 25 \mathrm{cdb}-2$ & Hole $S^{1}$ & 370607 & 1132247 & 3,082 & 2002 & $\mathrm{O}$ \\
\hline 46 & $(\mathrm{C}-42-14) 25 \mathrm{dba}-1$ & Basin 2 & 370616 & 1132219 & 3,042 & 1999 & $\mathrm{O}$ \\
\hline 47 & (C-42-14)25ddd-1 & WD 13 (Corral) & 370555 & 1132206 & 3,083 & - & $\mathrm{O}$ \\
\hline 48 & $(C-42-14) 26 a b b-1$ & Well 17 (West Dam) & 370638 & 1132334 & 3,027 & 2000 & $\mathrm{~W}$ \\
\hline 49 & (C-42-14)26bbb-1 & WD 14 (Terracor 2) & 370645 & 1132413 & 3,021 & 1970 & $\mathrm{O}$ \\
\hline 50 & (C-42-14)26bdd-1 & WD 7 (south end of West Dam) & 370626 & 1132342 & 3,075 & 2001 & $\mathrm{O}$ \\
\hline 51 & (C-42-14)26dad-1 & Hole K & 370612 & 1132306 & 3,070 & 2001 & $\mathrm{O}$ \\
\hline
\end{tabular}

${ }^{1}$ Drilled at a 45 degree angle.

${ }^{2}$ Water level affected by reservoir seepage. 
Table 1. Records of selected wells and boreholes in Sand Hollow, Utah-Continued

\begin{tabular}{|c|c|c|c|c|c|c|c|c|}
\hline \multirow[b]{2}{*}{$\begin{array}{c}\text { Map } \\
\text { number }\end{array}$} & \multirow[b]{2}{*}{$\begin{array}{c}\text { Depth of } \\
\text { well } \\
\text { (feet) }\end{array}$} & \multicolumn{3}{|c|}{ Casing } & \multicolumn{2}{|c|}{ Water level } & \multirow{2}{*}{$\begin{array}{c}\text { Depth of } \\
\text { openings } \\
\text { below water } \\
\text { table } \\
\text { (feet) }\end{array}$} & \multirow[b]{2}{*}{$\begin{array}{c}\text { Other data } \\
\text { available }\end{array}$} \\
\hline & & $\begin{array}{c}\text { Diameter } \\
\text { (inches) }\end{array}$ & $\begin{array}{c}\text { Bottom } \\
\text { (feet) }\end{array}$ & $\begin{array}{l}\text { Finish } \\
\text { (feet) }\end{array}$ & $\begin{array}{c}\text { Below land } \\
\text { surface } \\
\text { (feet) }\end{array}$ & $\begin{array}{c}\text { Date } \\
\text { measured }\end{array}$ & & \\
\hline 33 & 160 & 1 & 160 & F $150-160$ & 70.90 & 09/04/2001 & 79 to 89 & W, C, I \\
\hline 34 & 164 & 1 & 164 & F 144-164 & 95.64 & 09/04/2001 & 48 to 68 & W, C, I \\
\hline 35 & $88.6 \mathrm{~A}$ & - & - & - & $80 \mathrm{E}$ & - & 0 to 9 & $\mathrm{C}, \mathrm{I}$ \\
\hline 36 & 112 & 2 & 98.5 & F 93.5-98.5 & 77.42 & 09/04/2001 & 16 to 21 & W, C, I \\
\hline 37 & 155 & 2 & 155 & F $149.8-154.8$ & 141.95 & 09/04/2001 & 8 to 13 & W, C, I \\
\hline 38 & $111 \mathrm{~A}$ & 2 & 92.5 & F 87.3-92.3 & 51.20 & $06 / 15 / 2001$ & 36 to 41 & $\mathrm{C}, \mathrm{I}$ \\
\hline 39 & 143.6 & 2 & 130 & F $124.8-129.8$ & 92.66 & $09 / 12 / 2001$ & 32 to 37 & $\mathrm{C}, \mathrm{I}$ \\
\hline 40 & 98.8 & 8 & 8.5 & X 8.5-98.8 & 94 & 05/19/1999 & 0 to 5 & - \\
\hline 41 & $50 \mathrm{~A}$ & - & - & - & Dry & $05 / 26 / 2001$ & - & - \\
\hline 42 & $720 \mathrm{~A}$ & 12 & 4 & X 4-720 & 67.16 & 09/04/2001 & 0 to 653 & $\mathrm{C}, \mathrm{I}$ \\
\hline 43 & $73 \mathrm{~A}$ & 2 & 72 & F 66.8-71.8 & 66.35 & 09/04/2001 & .5 to 5.5 & $\mathrm{C}, \mathrm{I}$ \\
\hline 44 & 130 & 2 & 118.7 & F $113.5-118.5$ & 107.12 & 09/04/2001 & 6.4 to 11.4 & W, C, I \\
\hline 45 & 114 & - & - & - & - & - & - & - \\
\hline 46 & 143.6 A & 2 & 118 & F $112.8-117.8$ & 92.80 & $07 / 16 / 2001$ & 20 to 25 & $\mathrm{C}, \mathrm{I}$ \\
\hline 47 & $250 \mathrm{E}$ & - & - & - & 130.54 & 09/04/2001 & 0 to $120 \mathrm{E}$ & W, C, I \\
\hline 48 & 608 & 16 & 608 & S $140-580$ & 84.18 & 09/04/2001 & 56 to 496 & $\mathrm{C}, \mathrm{I}$ \\
\hline 49 & 645 & 8 & 5 & X 5-645 & 81.72 & 09/04/2001 & 0 to 563 & W, C, I \\
\hline 50 & 139.6 & 2 & 130 & F $124.8-129.8$ & 120.03 & 09/04/2001 & 4.8 to 9.8 & W, C, I \\
\hline 51 & $28.6 \mathrm{~A}$ & - & - & - & Dry & 05/17/2001 & - & - \\
\hline
\end{tabular}


Table 2. Water levels in selected wells in Sand Hollow, Utah

[Well location: See figure 2 for an explanation of the numbering system used for hydrologic-data sites in Utah. See table 1 for well information; see figure 3 for map location; Water Level: In feet below land surface. All water levels reported from Washington County Water ConservancyDistrict]

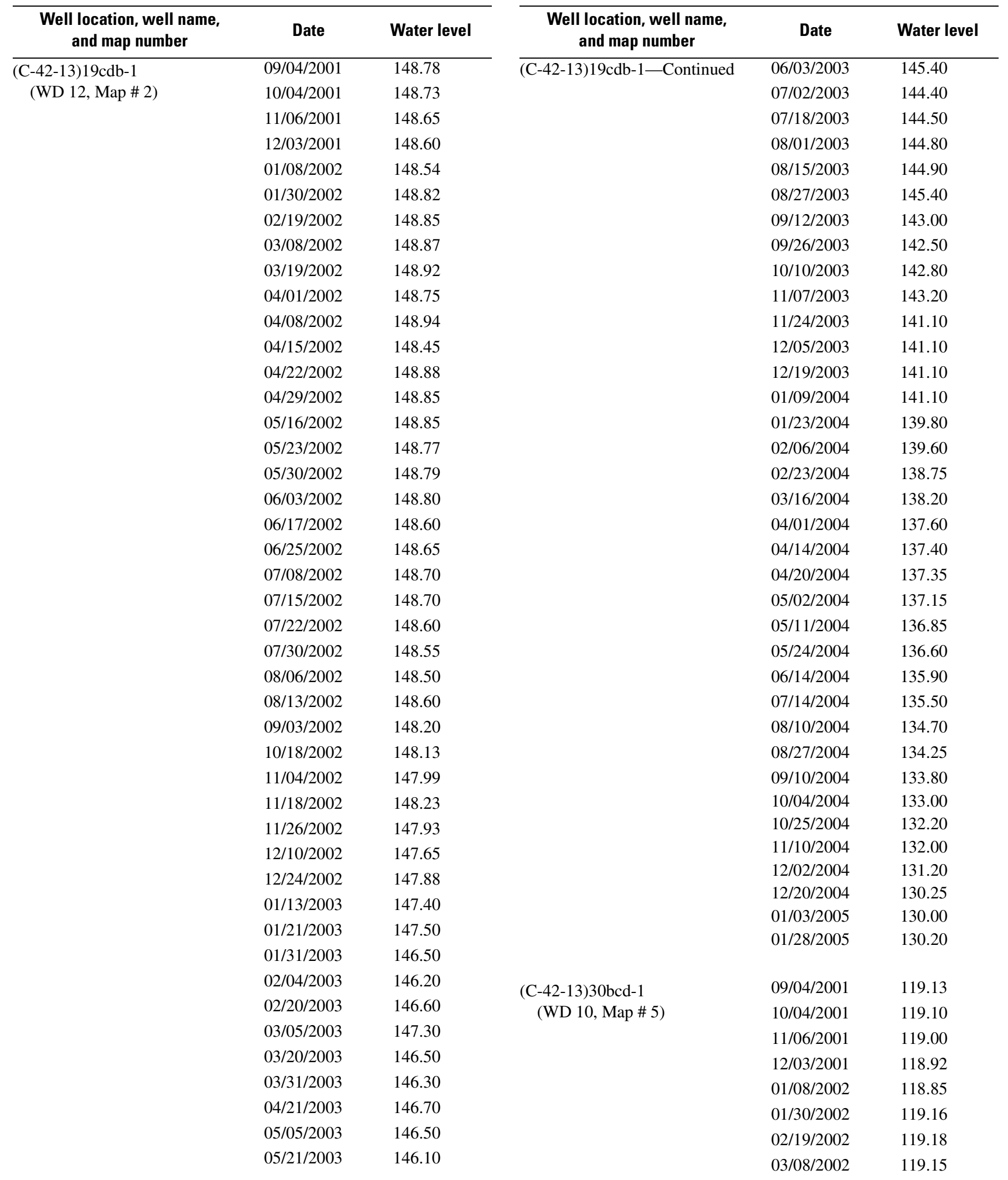


Table 2. Water levels in selected wells in Sand Hollow, Utah-Continued

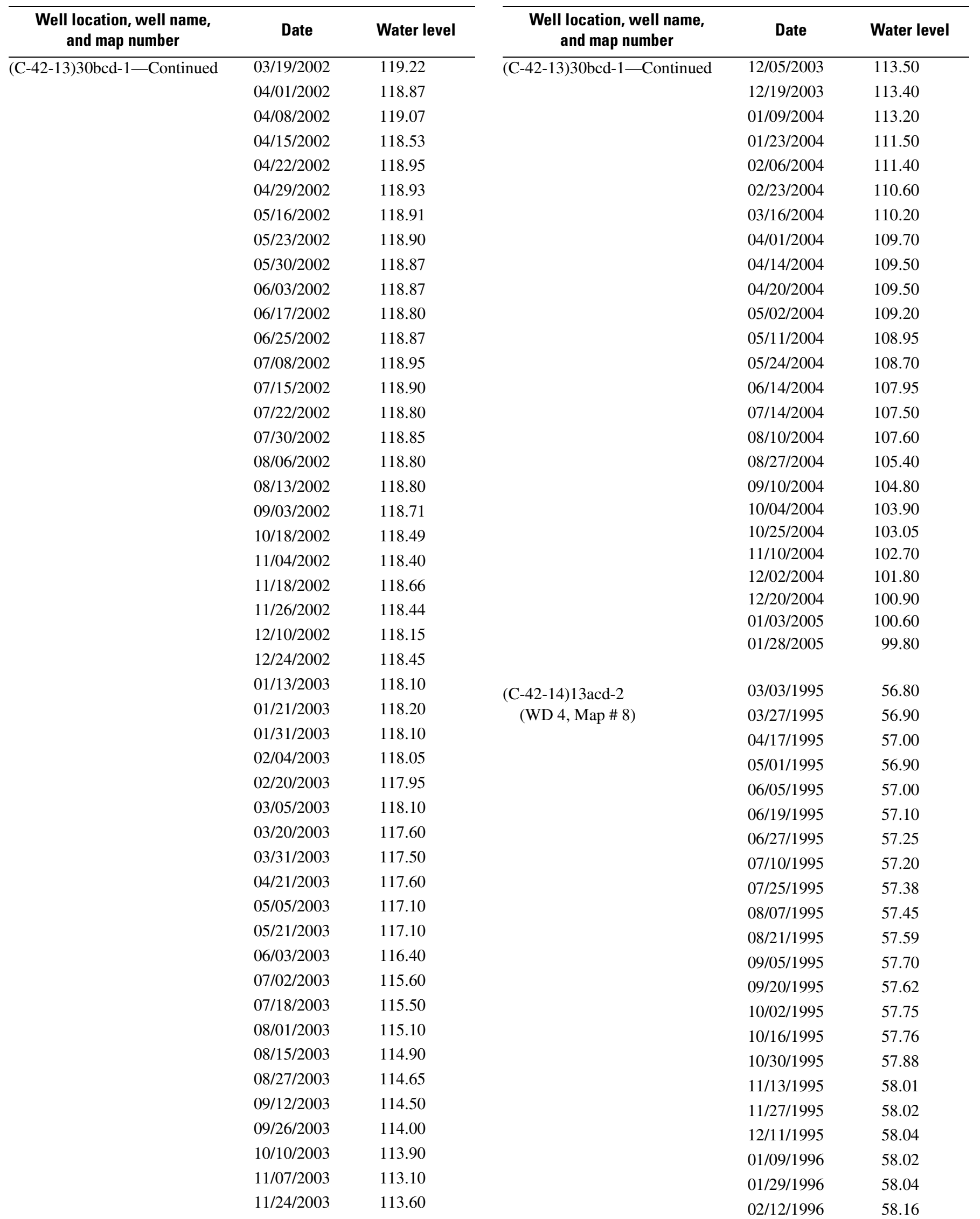


42 Pre- and Post-Reservoir Ground-Water Conditions at Sand Hollow, Washington County, Utah, 1995-2005

Table 2. Water levels in selected wells in Sand Hollow, Utah-Continued

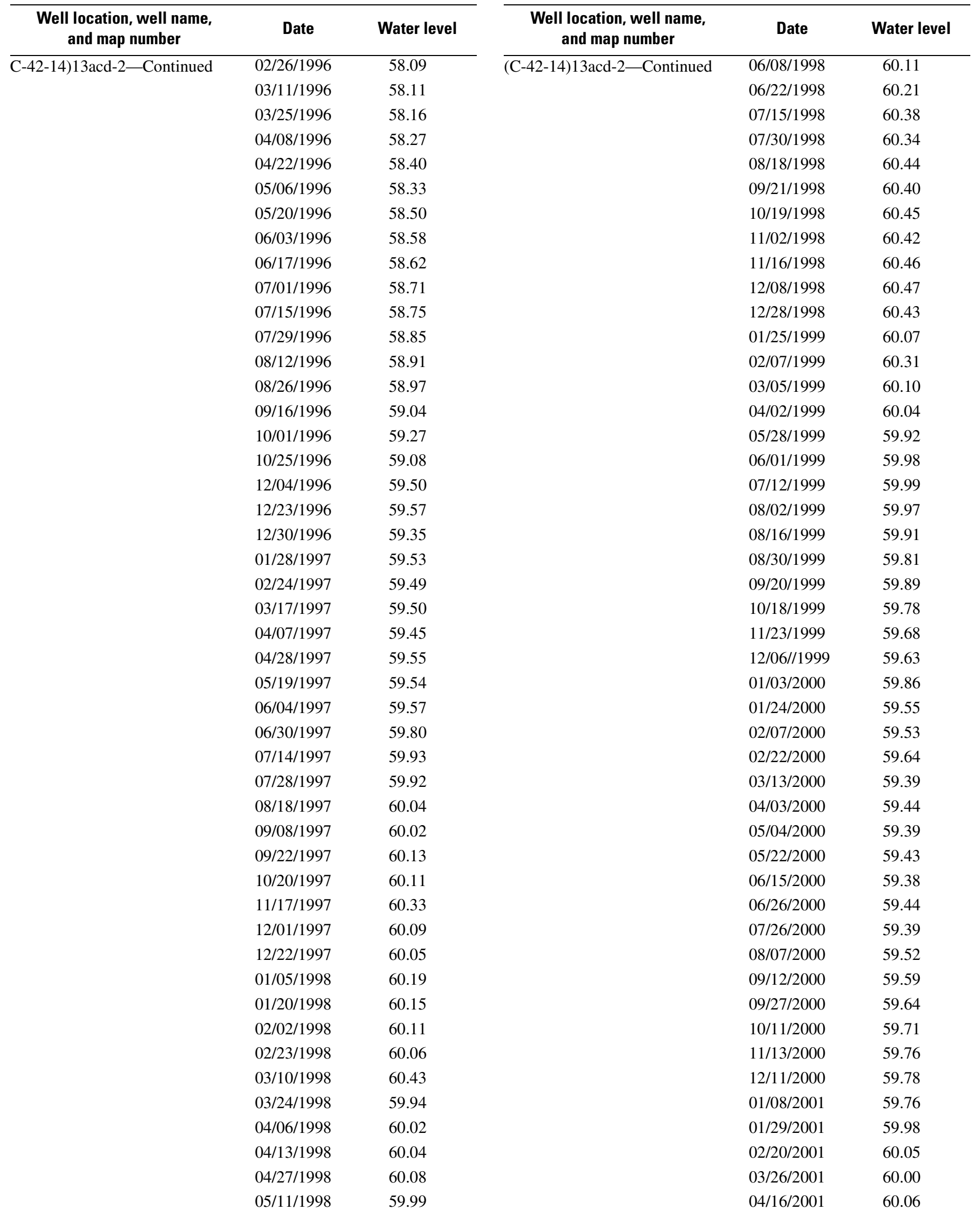


Tables

Table 2. Water levels in selected wells in Sand Hollow, Utah-Continued

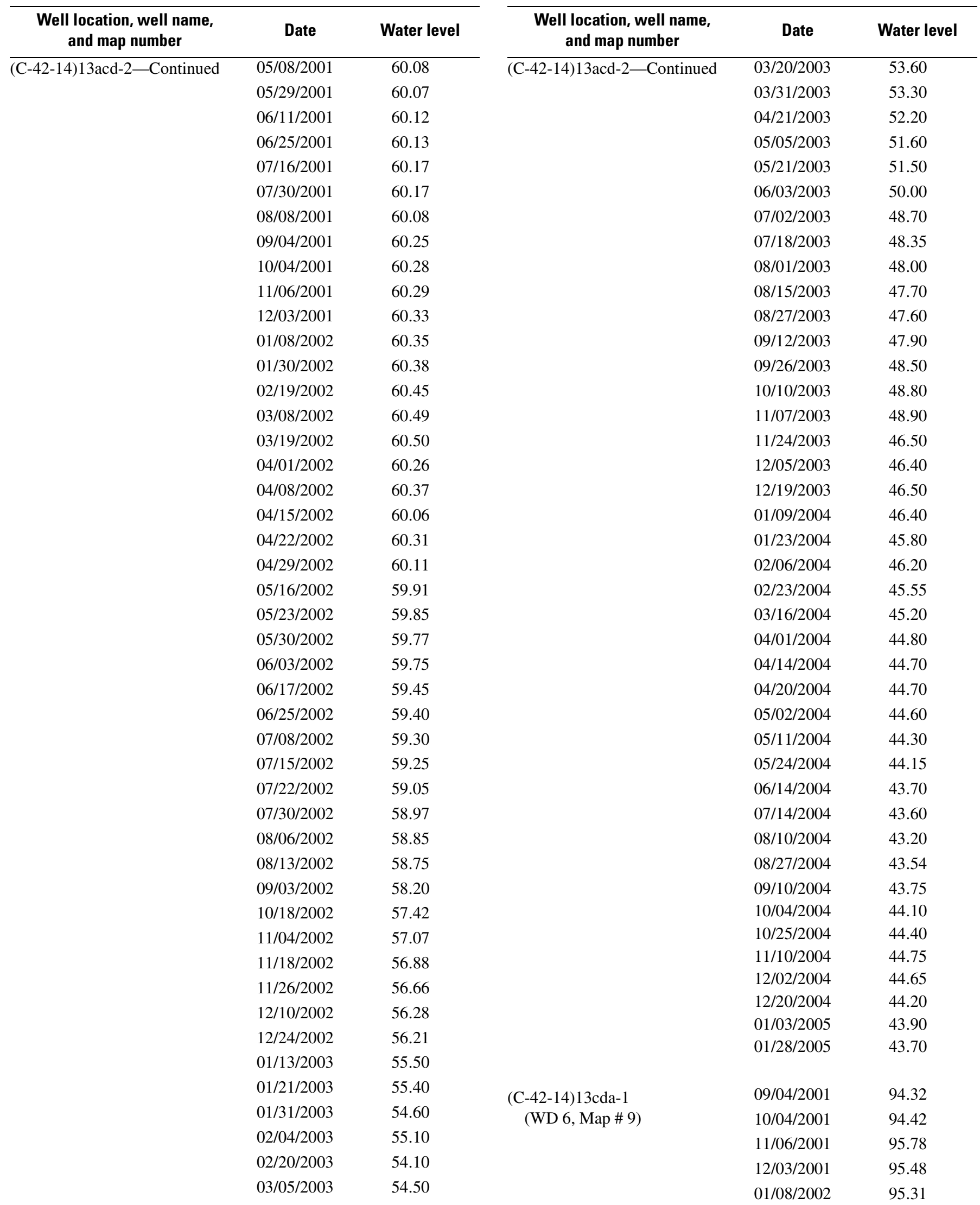


44 Pre- and Post-Reservoir Ground-Water Conditions at Sand Hollow, Washington County, Utah, 1995-2005

Table 2. Water levels in selected wells in Sand Hollow, Utah-Continued

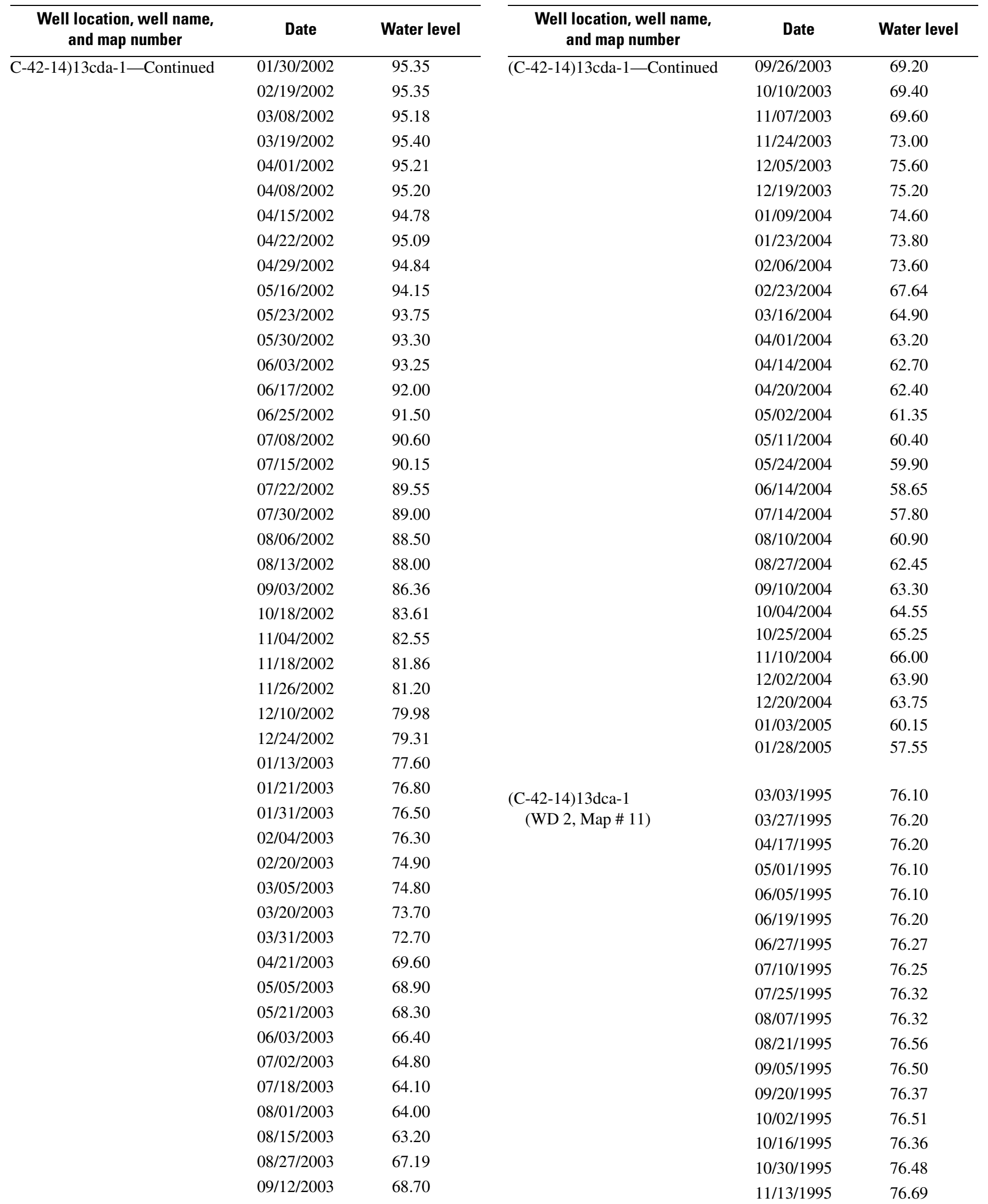


Tables

Table 2. Water levels in selected wells in Sand Hollow, Utah-Continued

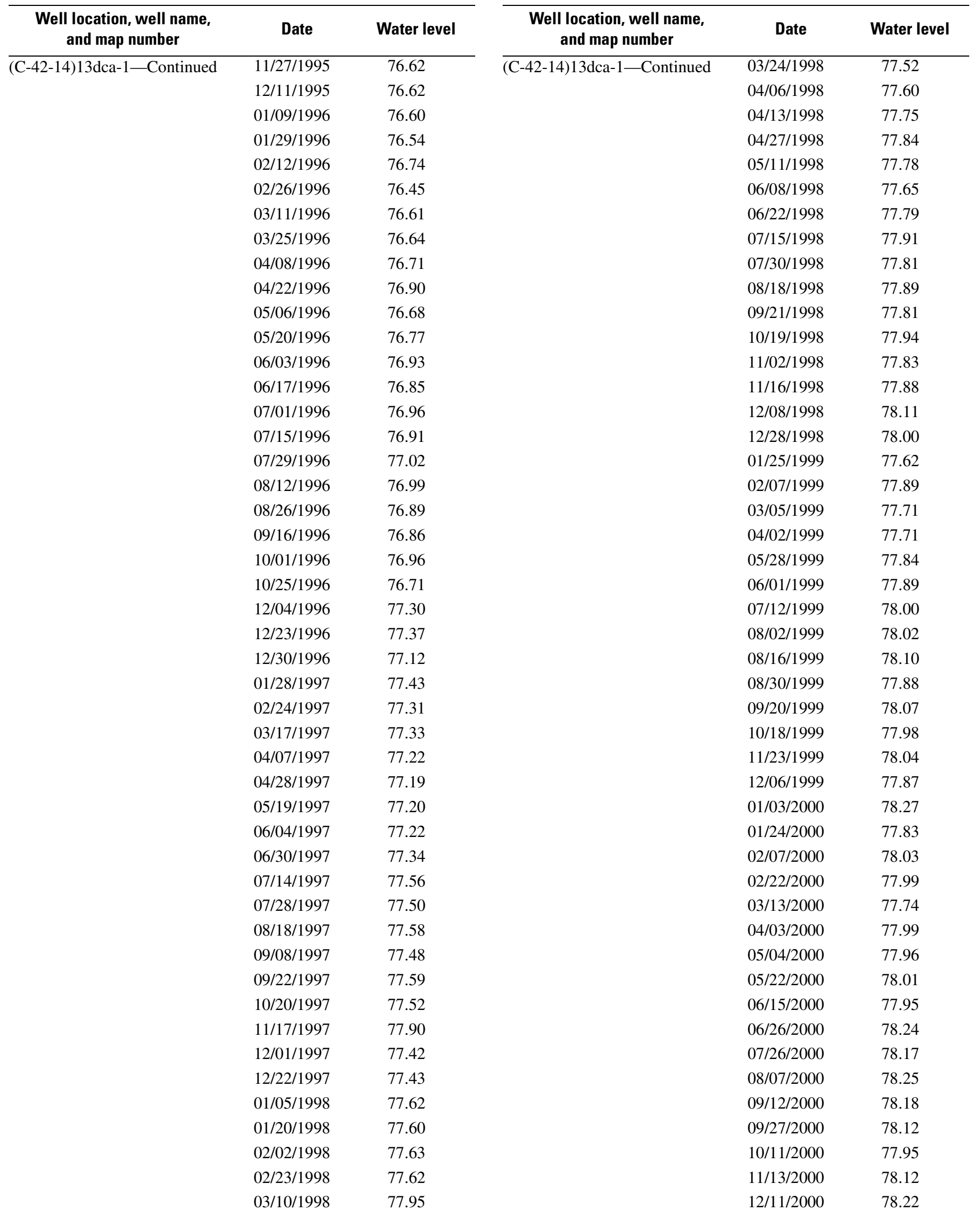


46 Pre- and Post-Reservoir Ground-Water Conditions at Sand Hollow, Washington County, Utah, 1995-2005

Table 2. Water levels in selected wells in Sand Hollow, Utah-Continued

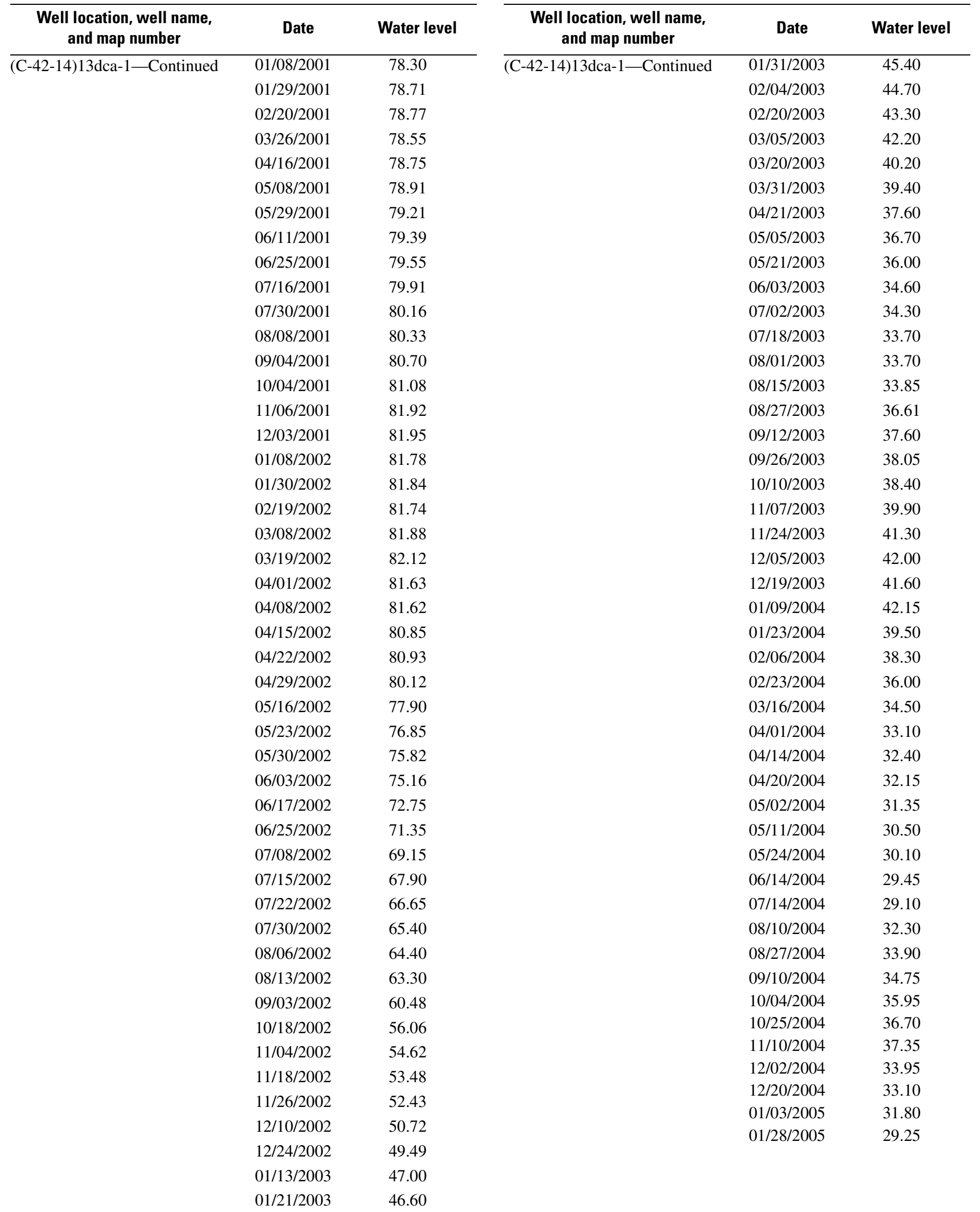


Tables

Table 2. Water levels in selected wells in Sand Hollow, Utah-Continued

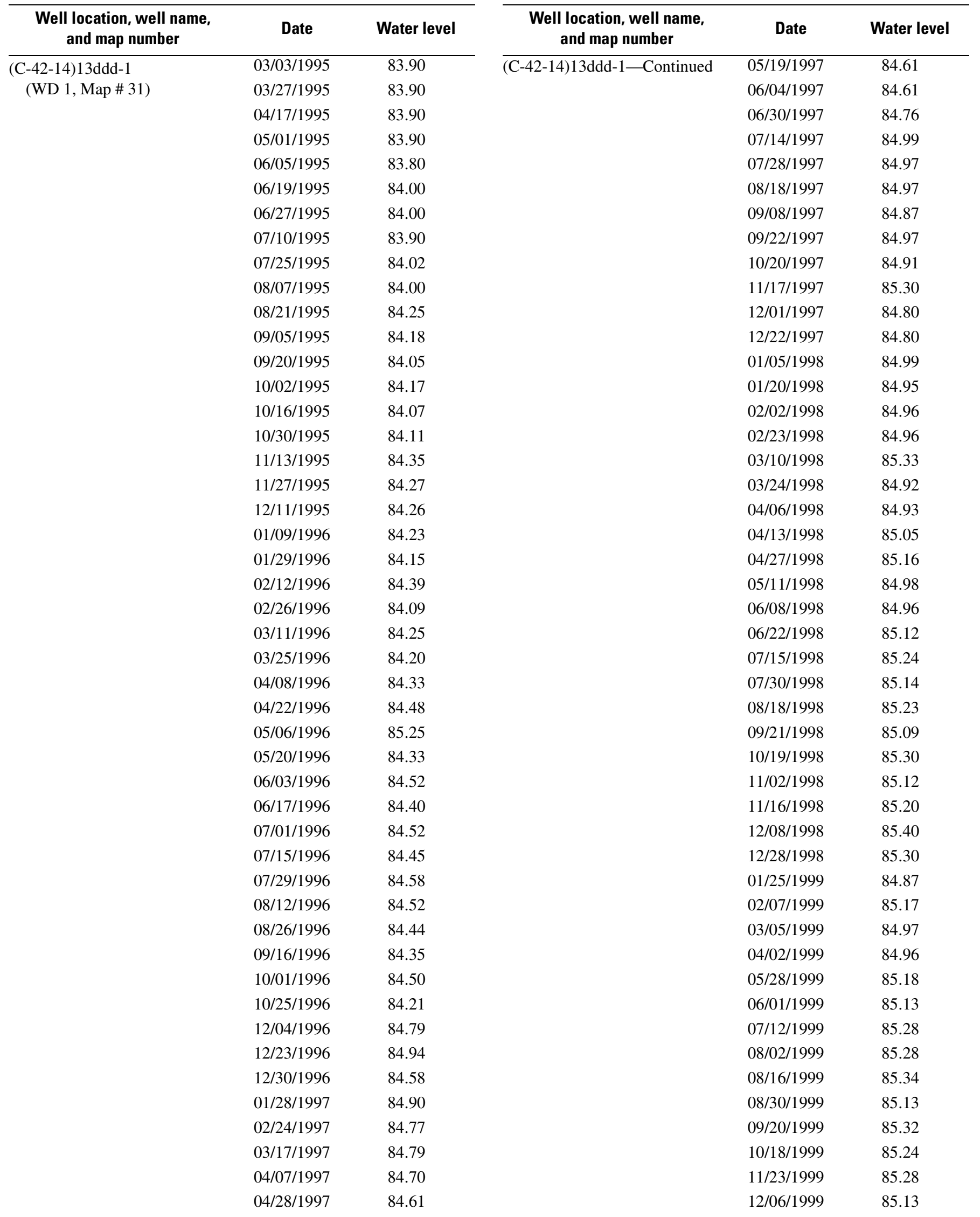


48 Pre- and Post-Reservoir Ground-Water Conditions at Sand Hollow, Washington County, Utah, 1995-2005

Table 2. Water levels in selected wells in Sand Hollow, Utah-Continued

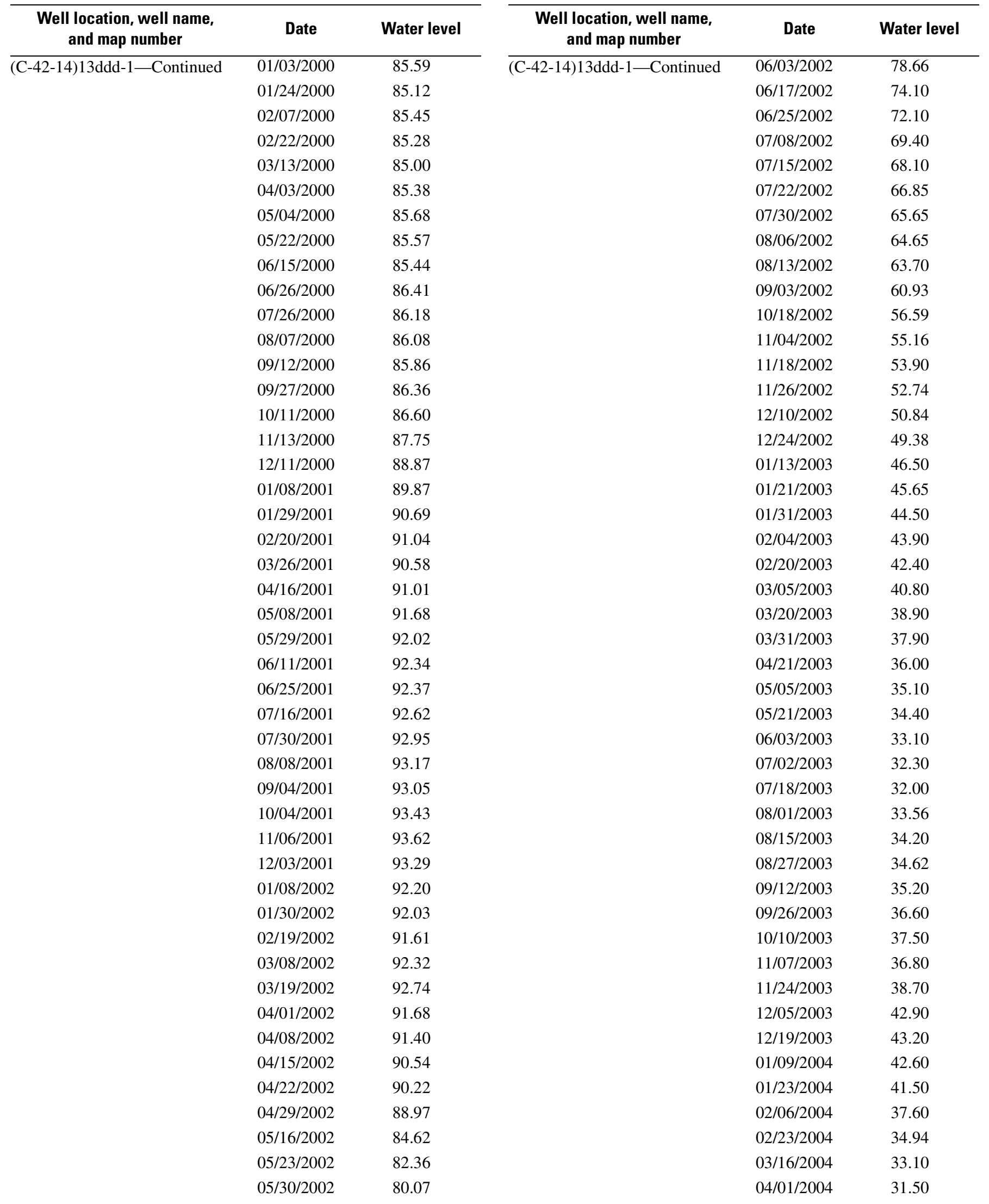


Tables

Table 2. Water levels in selected wells in Sand Hollow, Utah-Continued

\begin{tabular}{|c|c|c|c|c|c|}
\hline $\begin{array}{l}\text { Well location, well name, } \\
\text { and map number }\end{array}$ & Date & Water level & $\begin{array}{l}\text { Well location, well name, } \\
\text { and map number }\end{array}$ & Date & Water level \\
\hline \multirow[t]{17}{*}{ (C-42-14)13ddd-1—Continued } & $04 / 14 / 2004$ & 30.60 & $\overline{\text { (C-42-14)14aad-1-Continued }}$ & $06 / 03 / 1996$ & 54.18 \\
\hline & $04 / 20 / 2004$ & 30.30 & & 06/17/1996 & 54.16 \\
\hline & 05/02/2004 & 29.25 & & 07/01/1996 & 54.31 \\
\hline & $05 / 11 / 2004$ & 28.35 & & $07 / 15 / 1996$ & 54.60 \\
\hline & $05 / 24 / 2004$ & 27.65 & & 07/29/1996 & 54.48 \\
\hline & $06 / 14 / 2004$ & 27.25 & & 08/12/1996 & 54.55 \\
\hline & $07 / 14 / 2004$ & 26.90 & & 08/26/1996 & 54.47 \\
\hline & 08/10/2004 & 34.20 & & 09/16/1996 & 54.47 \\
\hline & 08/27/2004 & 38.50 & & 10/01/1996 & 54.60 \\
\hline & 09/10/2004 & 39.85 & & $10 / 25 / 1996$ & 54.33 \\
\hline & $10 / 04 / 2004$ & 41.60 & & $12 / 04 / 1996$ & 54.74 \\
\hline & $10 / 25 / 2004$ & 42.55 & & $12 / 23 / 1996$ & 54.74 \\
\hline & $11 / 10 / 2004$ & 43.55 & & $12 / 30 / 1996$ & 54.60 \\
\hline & $12 / 02 / 2004$ & 33.10 & & 01/28/1997 & 54.80 \\
\hline & $12 / 20 / 2004$ & 29.75 & & $02 / 24 / 1997$ & 54.73 \\
\hline & $01 / 03 / 2005$ & 28.40 & & 03/17/1997 & 54.82 \\
\hline & $01 / 28 / 2005$ & 26.50 & & $04 / 07 / 1997$ & 54.95 \\
\hline \multirow{29}{*}{$\begin{array}{l}\text { (C-42-14)14aad-1 } \\
\text { (WD RJ, Map \# 32) }\end{array}$} & 03/03/1995 & 52.30 & & 04/28/1997 & 54.91 \\
\hline & $03 / 27 / 1995$ & 52.60 & & 05/19/1997 & 54.91 \\
\hline & 04/17/1995 & 52.70 & & 06/04/1997 & 55.04 \\
\hline & 05/01/1995 & 52.70 & & 06/30/1997 & 55.20 \\
\hline & 06/05/1995 & 52.60 & & 07/14/1997 & 55.42 \\
\hline & 06/19/1995 & 52.80 & & 07/28/1997 & 55.42 \\
\hline & 06/27/1995 & 52.94 & & 08/18/1997 & 55.53 \\
\hline & 07/10/1995 & 52.91 & & 09/08/1997 & 55.36 \\
\hline & 07/25/1995 & 53.11 & & 09/22/1997 & 55.49 \\
\hline & 08/07/1995 & 53.11 & & $10 / 20 / 1997$ & 55.45 \\
\hline & 08/21/1995 & 53.34 & & $11 / 17 / 1997$ & 55.73 \\
\hline & 09/05/1995 & 53.40 & & $12 / 01 / 1997$ & 55.36 \\
\hline & 09/20/1995 & 53.45 & & $12 / 22 / 1997$ & 55.21 \\
\hline & $10 / 02 / 1995$ & 53.48 & & 01/05/1998 & 55.57 \\
\hline & $10 / 16 / 1995$ & 53.41 & & 01/20/1998 & 55.48 \\
\hline & $10 / 30 / 1995$ & 53.46 & & 02/02/1998 & 55.50 \\
\hline & $11 / 13 / 1995$ & 53.55 & & 02/23/1998 & 55.50 \\
\hline & $11 / 27 / 1995$ & 53.52 & & 03/10/1998 & 55.74 \\
\hline & $12 / 11 / 1995$ & 53.45 & & 03/24/1998 & 55.49 \\
\hline & 01/09/1996 & 53.52 & & 04/06/1998 & 55.47 \\
\hline & 01/29/1996 & 53.48 & & 04/13/1998 & 55.58 \\
\hline & $02 / 12 / 1996$ & 53.65 & & $04 / 27 / 1998$ & 55.66 \\
\hline & $02 / 26 / 1996$ & 53.37 & & 05/11/1998 & 55.62 \\
\hline & 03/11/1996 & 53.52 & & 06/08/1998 & 55.88 \\
\hline & 03/25/1996 & 53.58 & & 06/22/1998 & 55.94 \\
\hline & 04/08/1996 & 53.75 & & 07/15/1998 & 56.14 \\
\hline & 04/22/1996 & 54.00 & & 07/30/1998 & 56.10 \\
\hline & 05/06/1996 & 53.89 & & 08/18/1998 & 56.29 \\
\hline & 05/20/1996 & 54.01 & & 09/21/1998 & 56.16 \\
\hline
\end{tabular}


50 Pre- and Post-Reservoir Ground-Water Conditions at Sand Hollow, Washington County, Utah, 1995-2005

Table 2. Water levels in selected wells in Sand Hollow, Utah-Continued

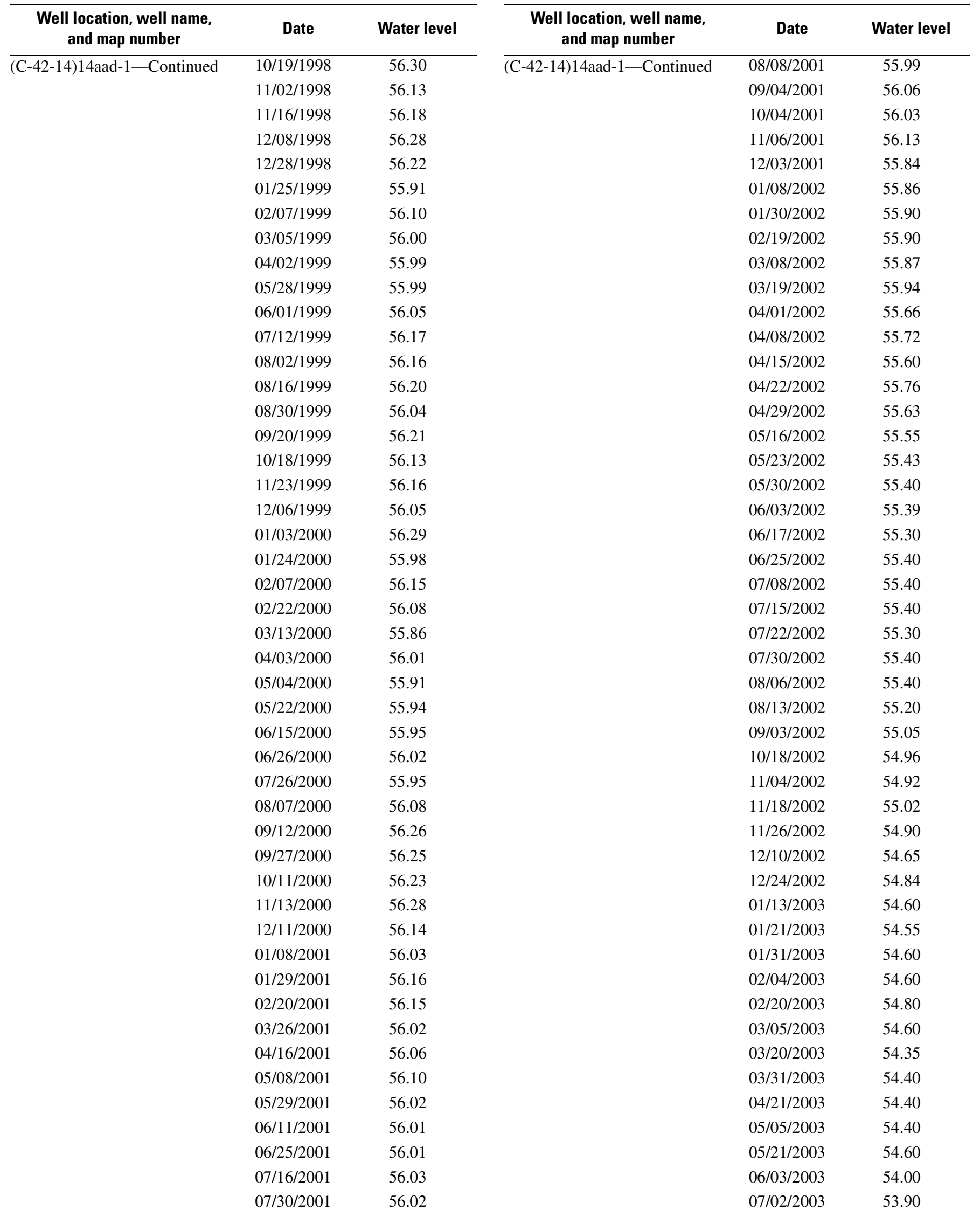


Tables 51

Table 2. Water levels in selected wells in Sand Hollow, Utah-Continued

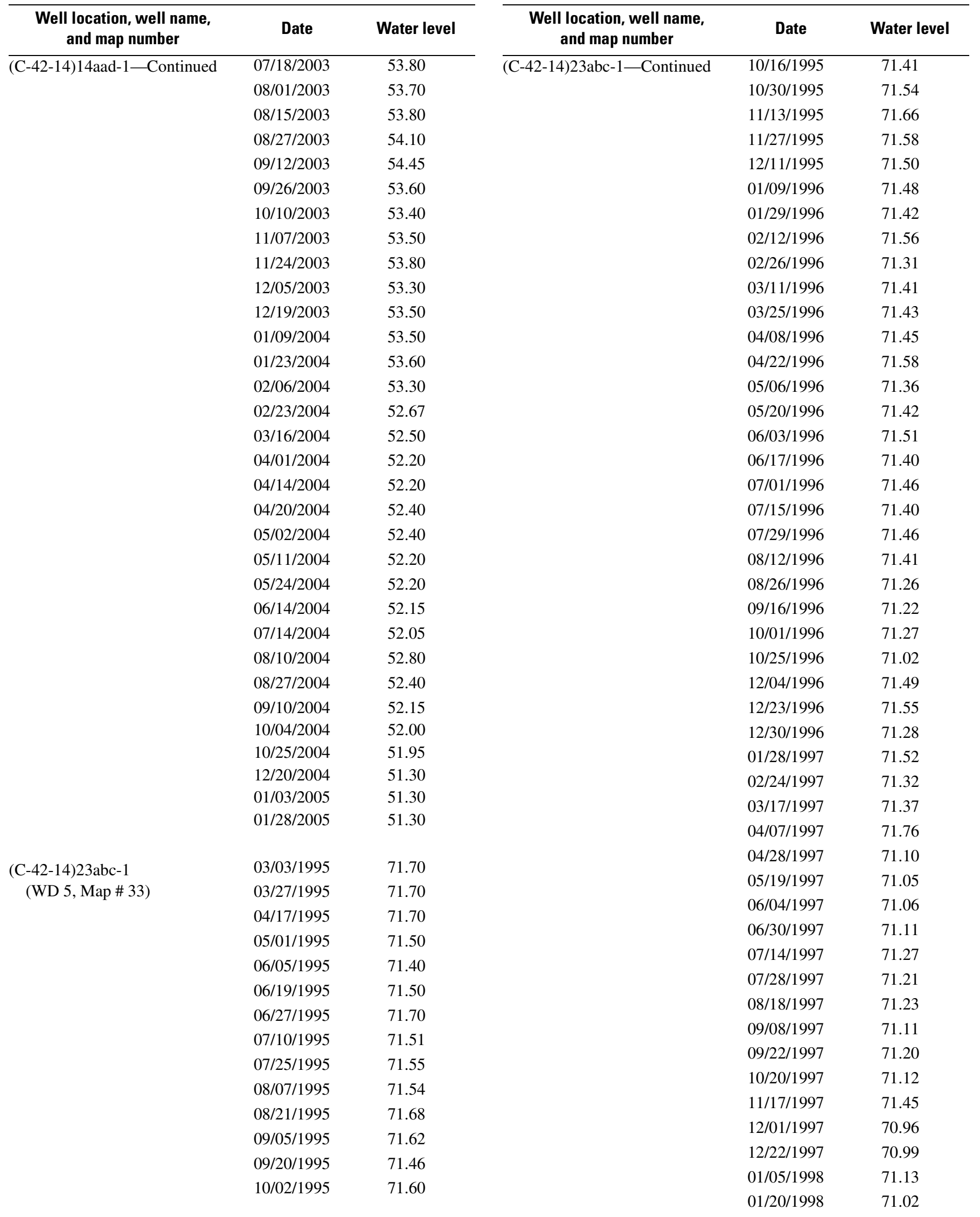


52 Pre- and Post-Reservoir Ground-Water Conditions at Sand Hollow, Washington County, Utah, 1995-2005

Table 2. Water levels in selected wells in Sand Hollow, Utah-Continued

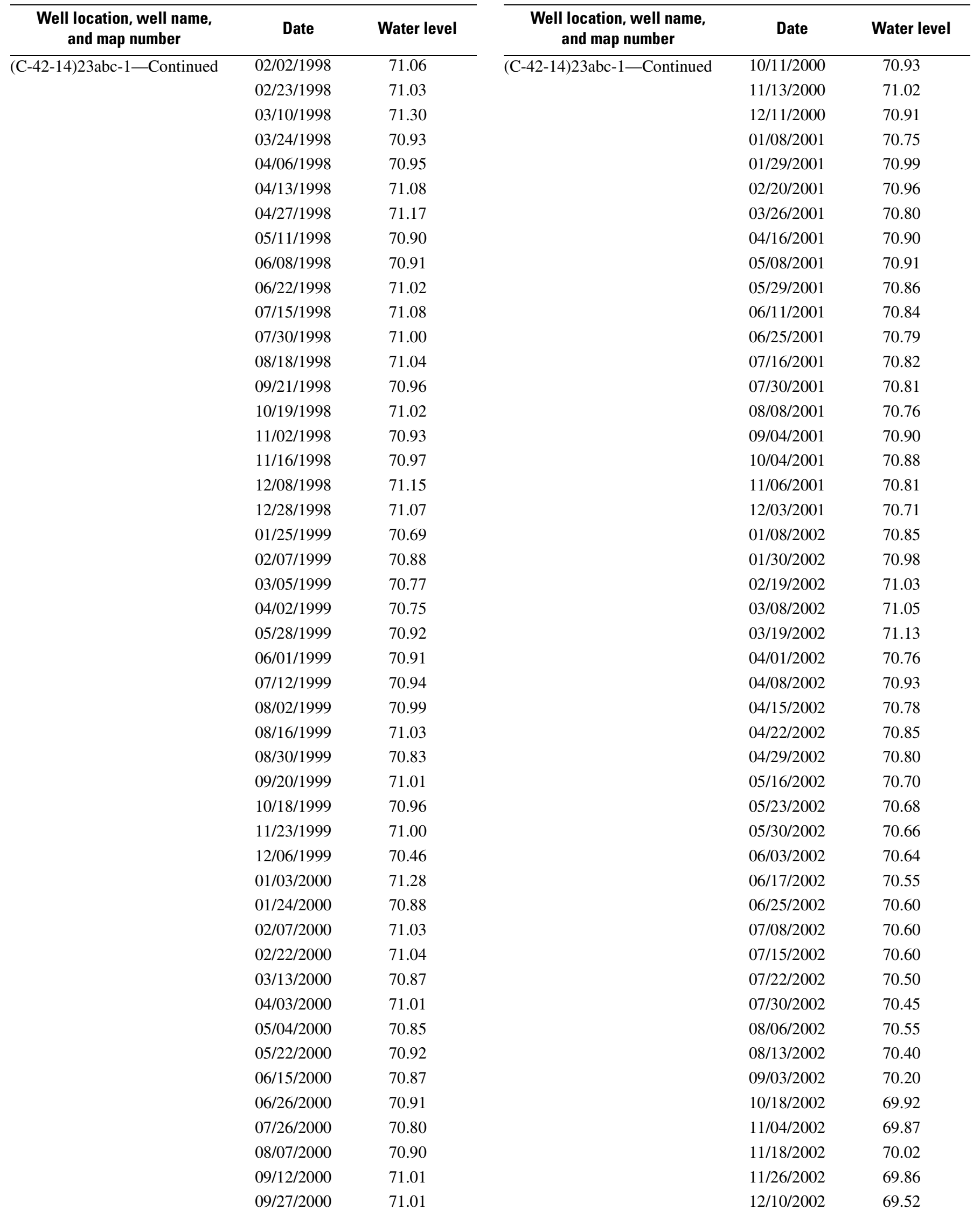


Tables 53

Table 2. Water levels in selected wells in Sand Hollow, Utah-Continued

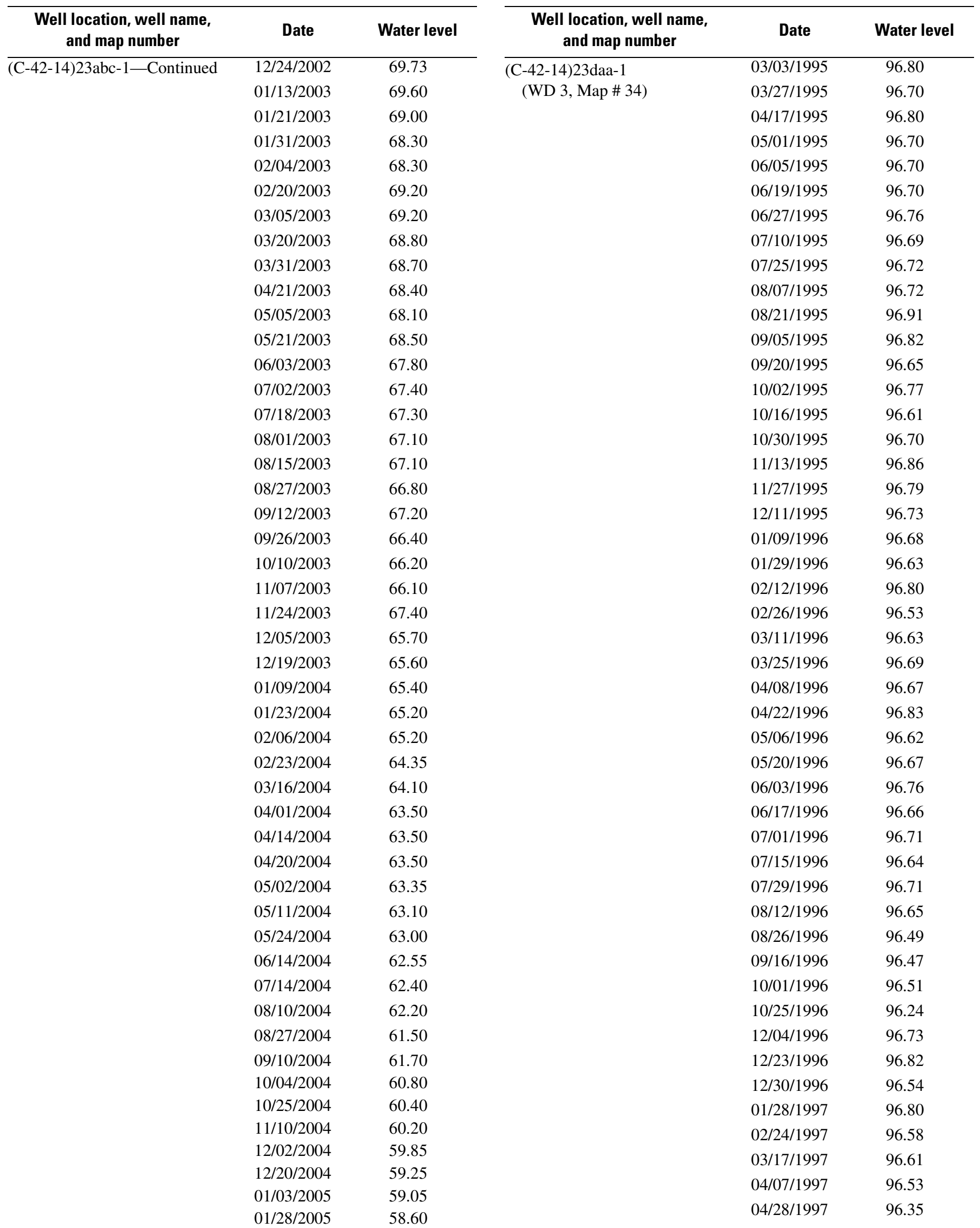


54 Pre- and Post-Reservoir Ground-Water Conditions at Sand Hollow, Washington County, Utah, 1995-2005

Table 2. Water levels in selected wells in Sand Hollow, Utah-Continued

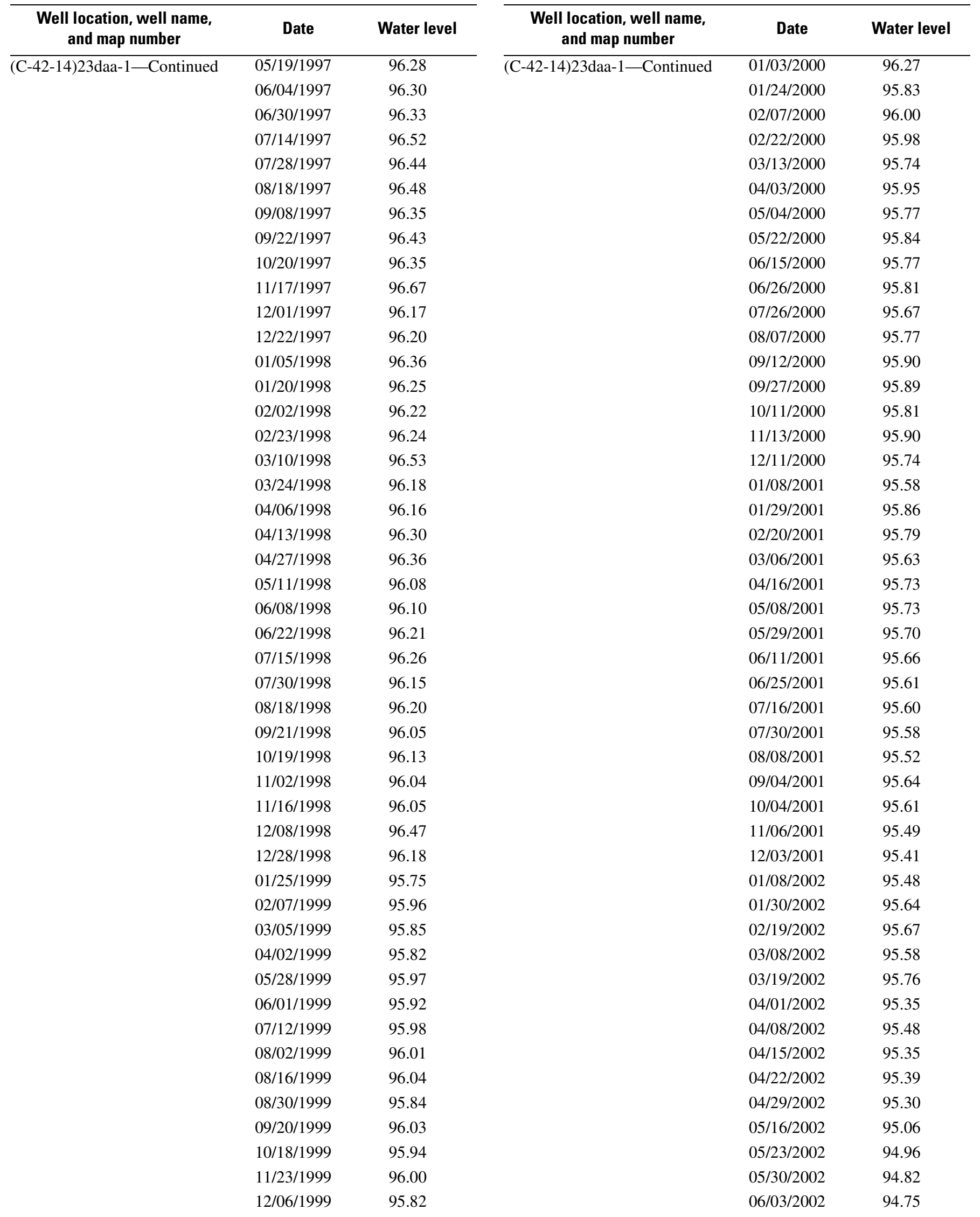


Tables 55

Table 2. Water levels in selected wells in Sand Hollow, Utah-Continued

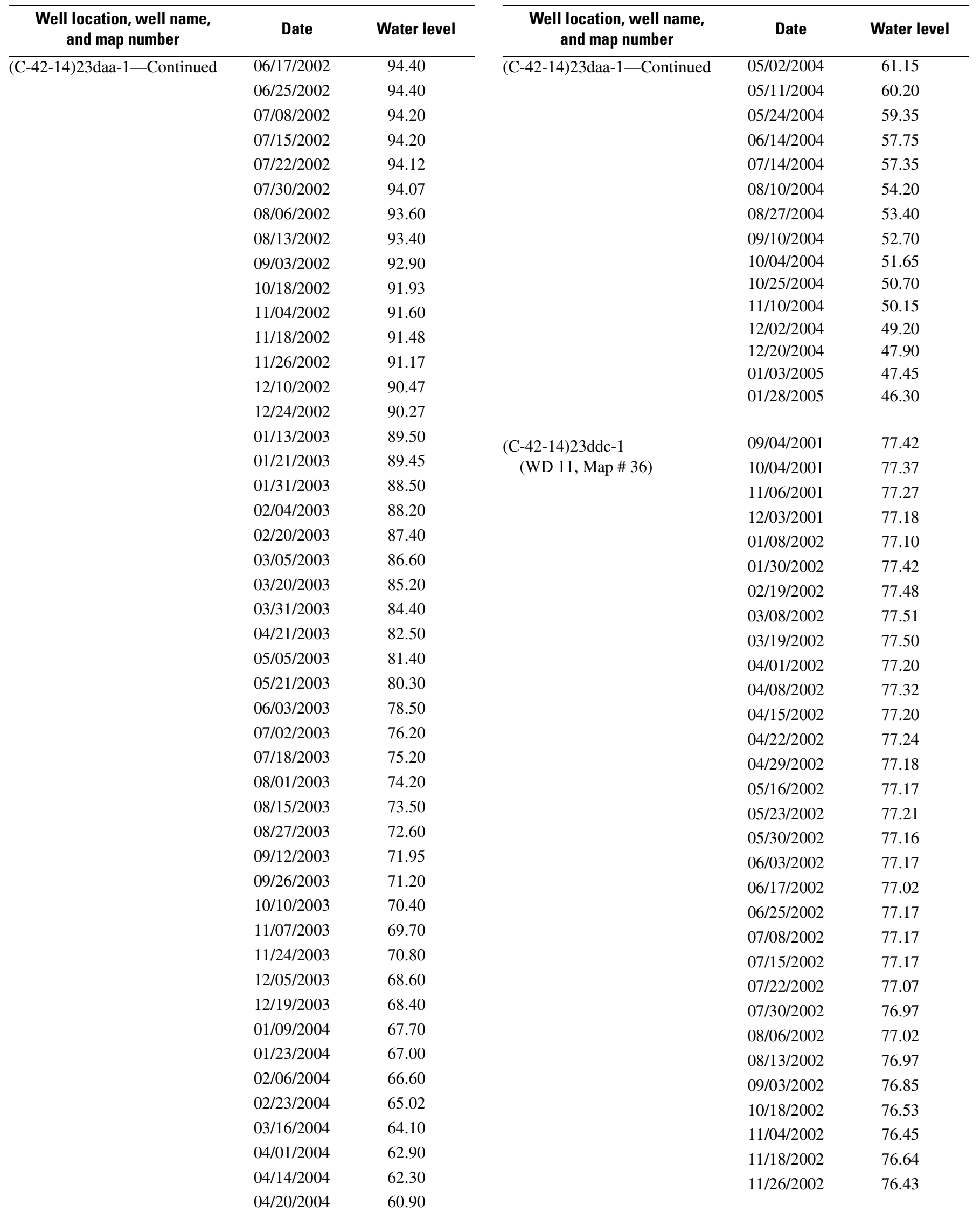


56 Pre- and Post-Reservoir Ground-Water Conditions at Sand Hollow, Washington County, Utah, 1995-2005

Table 2. Water levels in selected wells in Sand Hollow, Utah-Continued

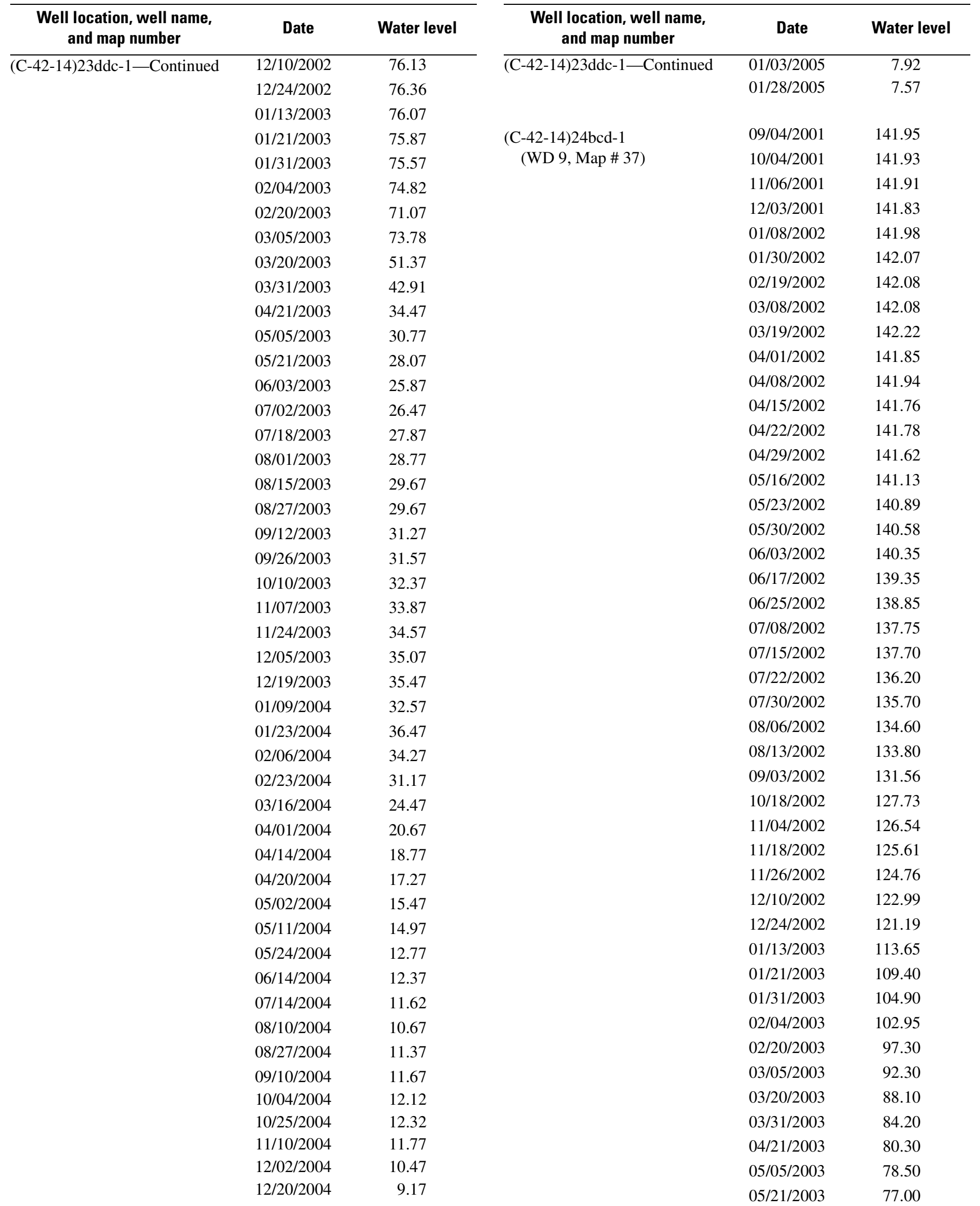


Tables 57

Table 2. Water levels in selected wells in Sand Hollow, Utah—Continued

\begin{tabular}{|c|c|c|c|c|c|}
\hline $\begin{array}{l}\text { Well location, well name, } \\
\text { and map number }\end{array}$ & Date & Water level & $\begin{array}{l}\text { Well location, well name, } \\
\text { and map number }\end{array}$ & Date & Water level \\
\hline \multirow[t]{36}{*}{ (C-42-14)24bcd-1-Continued } & $06 / 03 / 2003$ & 75.40 & $\overline{(\mathrm{C}-42-14) 25 \mathrm{cdb}-1-\text { Continued }}$ & $04 / 08 / 2002$ & 107.61 \\
\hline & 07/02/2003 & 76.70 & & $04 / 15 / 2002$ & 107.16 \\
\hline & 07/18/2003 & 77.50 & & 04/22/2002 & 107.55 \\
\hline & 08/01/2003 & 79.50 & & $04 / 29 / 2002$ & 107.54 \\
\hline & $08 / 15 / 2003$ & 81.30 & & 05/16/2002 & 107.56 \\
\hline & $08 / 27 / 2003$ & 82.30 & & $05 / 23 / 2002$ & 107.58 \\
\hline & 09/12/2003 & 83.70 & & 05/30/2002 & 107.61 \\
\hline & $09 / 26 / 2003$ & 84.50 & & $06 / 03 / 2002$ & 107.58 \\
\hline & $10 / 10 / 2003$ & 85.20 & & 06/17/2002 & 107.48 \\
\hline & $11 / 07 / 2003$ & 87.10 & & $06 / 25 / 2002$ & 107.63 \\
\hline & $11 / 24 / 2003$ & 87.80 & & 07/08/2002 & 107.68 \\
\hline & $12 / 05 / 2003$ & 88.20 & & $07 / 15 / 2002$ & 107.78 \\
\hline & $12 / 19 / 2003$ & 88.70 & & $07 / 22 / 2002$ & 107.58 \\
\hline & 01/09/2004 & 86.80 & & 07/30/2002 & 107.61 \\
\hline & $01 / 23 / 2004$ & 83.40 & & 08/06/2002 & 107.58 \\
\hline & $02 / 06 / 2004$ & 80.70 & & 08/13/2002 & 107.66 \\
\hline & $02 / 23 / 2004$ & 76.85 & & 09/03/2002 & 107.59 \\
\hline & 03/16/2004 & 73.80 & & $10 / 18 / 2002$ & 107.44 \\
\hline & $04 / 01 / 2004$ & 71.10 & & $11 / 04 / 2002$ & 107.43 \\
\hline & $04 / 14 / 2004$ & 69.00 & & $11 / 18 / 2002$ & 107.73 \\
\hline & $04 / 20 / 2004$ & 68.40 & & $11 / 26 / 2002$ & 107.52 \\
\hline & $05 / 02 / 2004$ & 65.80 & & $12 / 10 / 2002$ & 107.32 \\
\hline & $05 / 11 / 2004$ & 64.00 & & $12 / 24 / 2002$ & 107.60 \\
\hline & $05 / 24 / 2004$ & 62.50 & & $01 / 13 / 2003$ & 110.58 \\
\hline & $06 / 14 / 2004$ & 61.10 & & $01 / 21 / 2003$ & 107.48 \\
\hline & 07/14/2004 & 60.60 & & $01 / 31 / 2003$ & 110.38 \\
\hline & 08/10/2004 & 60.80 & & $02 / 04 / 2003$ & 110.38 \\
\hline & 08/27/2004 & 61.15 & & $02 / 20 / 2003$ & 110.48 \\
\hline & 09/10/2004 & 61.45 & & $03 / 05 / 2003$ & 110.48 \\
\hline & $10 / 04 / 2004$ & 62.00 & & $03 / 20 / 2003$ & 110.08 \\
\hline & $10 / 25 / 2004$ & 62.30 & & $03 / 31 / 2003$ & 110.18 \\
\hline & $11 / 10 / 2004$ & 62.30 & & $04 / 21 / 2003$ & 110.08 \\
\hline & $12 / 02 / 2004$ & 61.35 & & $05 / 05 / 2003$ & 110.08 \\
\hline & $12 / 20 / 2004$ & 60.05 & & $05 / 21 / 2003$ & 110.08 \\
\hline & 01/03/2005 & 59.70 & & $06 / 03 / 2003$ & 109.58 \\
\hline & $01 / 28 / 2005$ & 58.15 & & $07 / 02 / 2003$ & $\begin{array}{l}109.00 \\
108.98\end{array}$ \\
\hline \multirow{11}{*}{$\begin{array}{l}\text { (C-42-14)25cdb-1 } \\
\text { (WD 8, Map \# 44) }\end{array}$} & 09/04/2001 & 107.12 & & $07 / 18 / 2003$ & 108.83 \\
\hline & $10 / 04 / 2001$ & 107.30 & & $08 / 01 / 2003$ & 108.58 \\
\hline & $11 / 06 / 2001$ & 107.41 & & $08 / 15 / 2003$ & 108.38 \\
\hline & $12 / 03 / 2001$ & 107.38 & & $08 / 27 / 2003$ & 107.98 \\
\hline & $01 / 08 / 2002$ & 107.37 & & 09/12/2003 & 107.78 \\
\hline & $01 / 30 / 2002$ & 107.71 & & $09 / 26 / 2003$ & 107.28 \\
\hline & 02/19/2002 & 107.74 & & $10 / 10 / 2003$ & 107.08 \\
\hline & 03/08/2002 & 107.79 & & $11 / 07 / 2003$ & 106.68 \\
\hline & 03/19/2002 & 107.80 & & $11 / 24 / 2003$ & 106.18 \\
\hline & $04 / 01 / 2002$ & 107.48 & & $12 / 05 / 2003$ & 105.98 \\
\hline & & & & $12 / 19 / 2003$ & 106.08 \\
\hline
\end{tabular}


58 Pre- and Post-Reservoir Ground-Water Conditions at Sand Hollow, Washington County, Utah, 1995-2005

Table 2. Water levels in selected wells in Sand Hollow, Utah-Continued

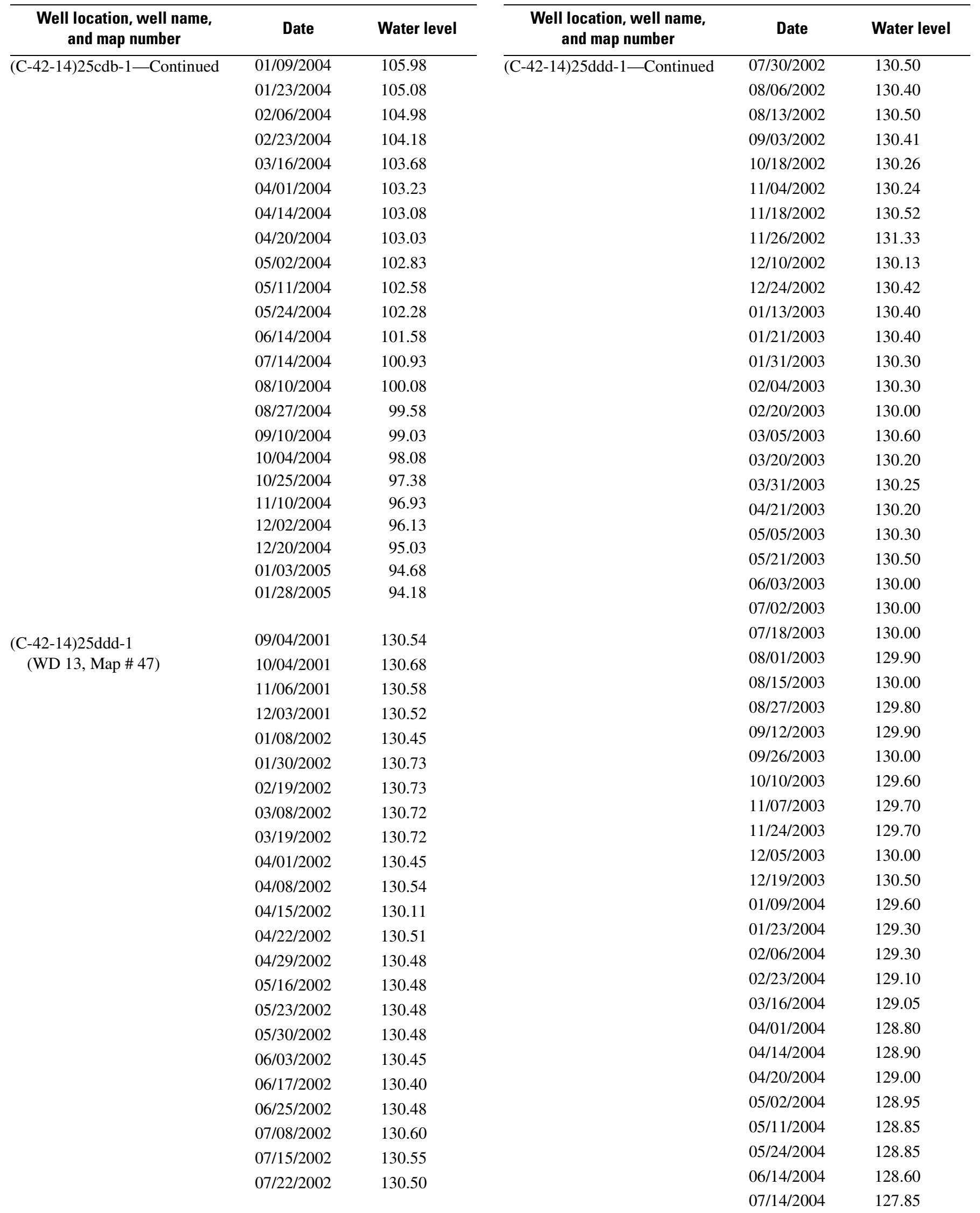


Tables 59

Table 2. Water levels in selected wells in Sand Hollow, Utah—Continued

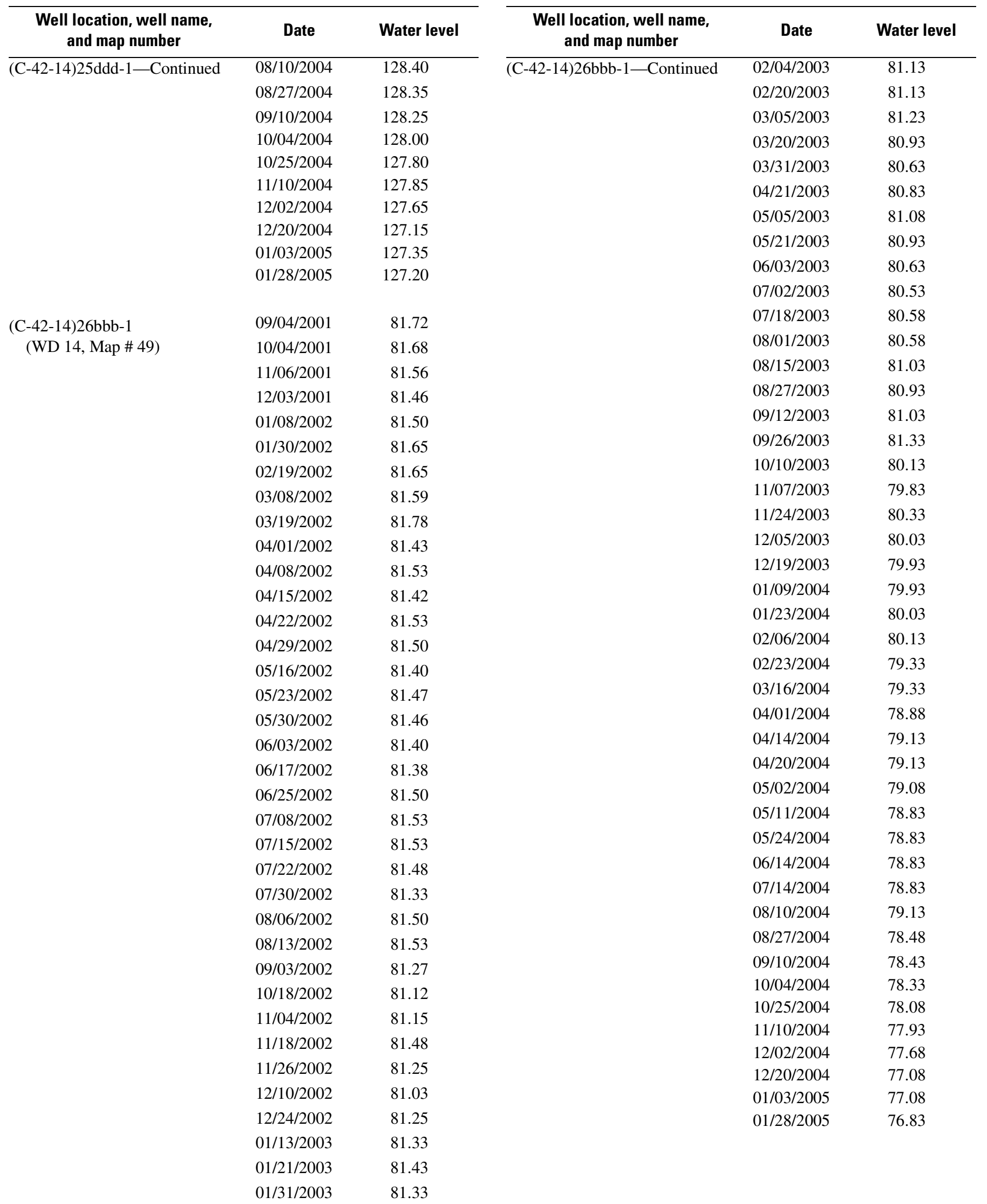


60 Pre- and Post-Reservoir Ground-Water Conditions at Sand Hollow, Washington County, Utah, 1995-2005

Table 2. Water levels in selected wells in Sand Hollow, Utah-Continued

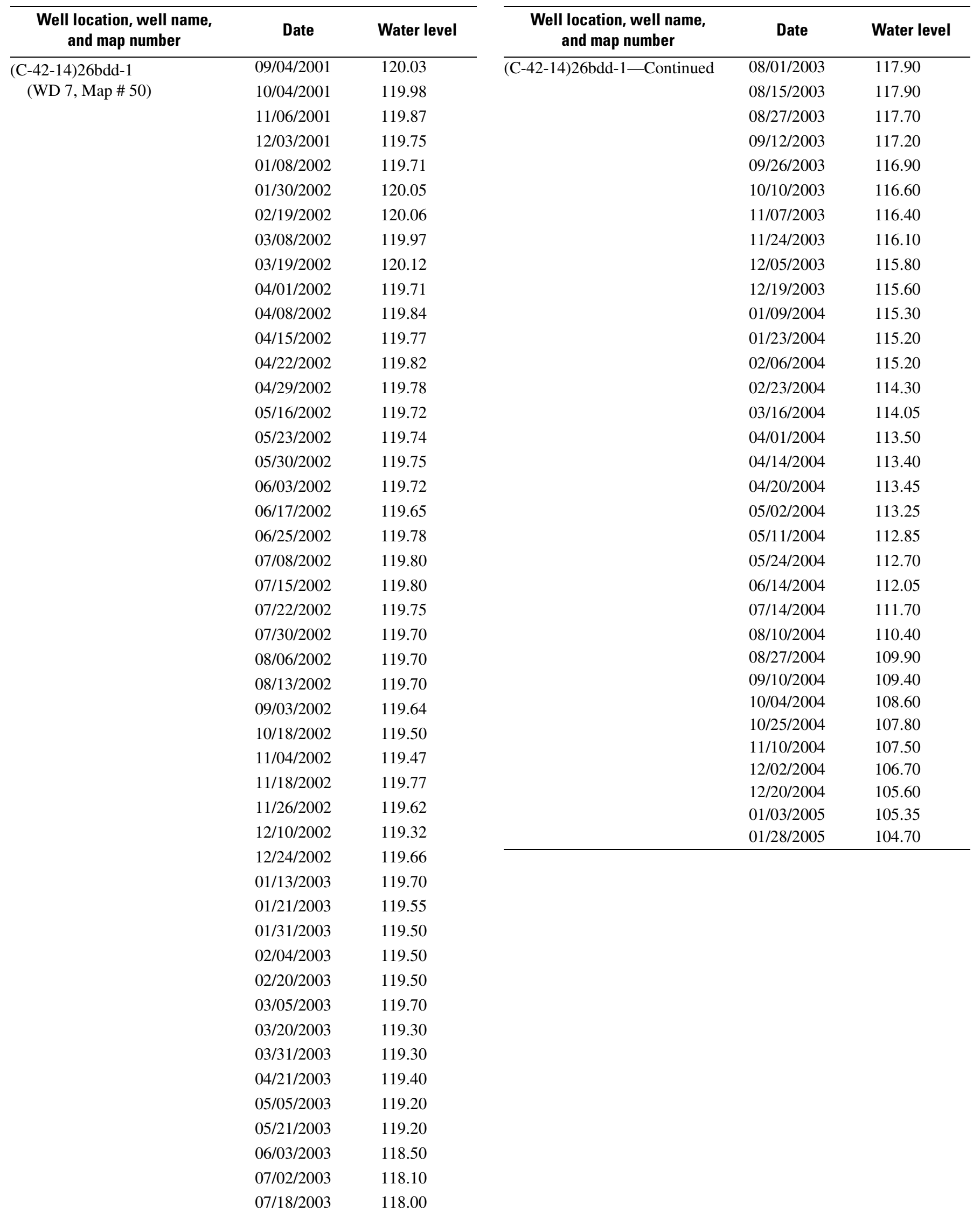


Table 3. Selected physical properties and major and minor chemical constituents in ground- and surface-water samples collected from selected sites in Sand Hollow and the Virgin River near Virgin, Utah

[Map number: Refer to figure 3 and table 1; Specific conductance: $\mu \mathrm{S} / \mathrm{cm}$, microsiemens per centimeter at 25 degrees Celsius. Analyzing agency for all samples (except where noted): U.S. Geological Survey National Water-Quality Laboratory in Denver, Colorado; mg/L, milligrams per liter; $\mu \mathrm{g} / \mathrm{L}$, micrograms per liter; —, no data available; <, less than; E, estimated]

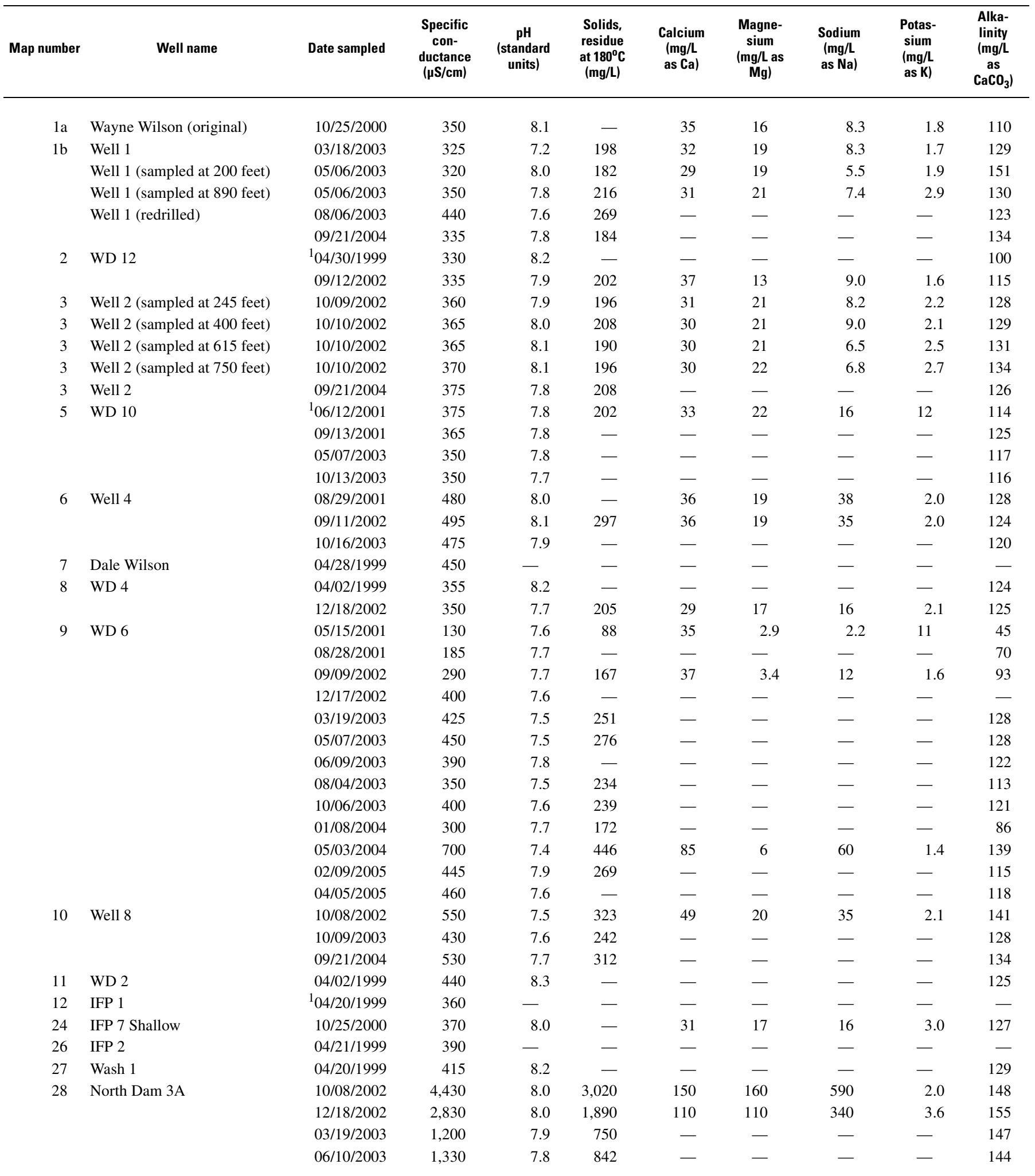


Table 3. Selected physical properties and major and minor chemical constituents in ground- and surface-water samples collected from selected sites in Sand Hollow and the Virgin River near Virgin, Utah-Continued

\begin{tabular}{|c|c|c|c|c|c|c|c|c|c|c|c|c|c|}
\hline Map number & $\begin{array}{l}\text { Sulfate } \\
(\mathrm{mg} / \mathrm{L} \text { as } \\
\left.\mathrm{SO}_{4}\right)\end{array}$ & $\begin{array}{l}\text { Chloride } \\
\text { (mg/L as } \\
\text { Cl) }\end{array}$ & $\begin{array}{l}\text { Fluoride } \\
\text { (mg/L as F) }\end{array}$ & $\begin{array}{l}\text { Bromide } \\
\text { (mg/L as } \\
\mathrm{Br})\end{array}$ & $\begin{array}{l}\text { Chloride: } \\
\text { Bromide } \\
\text { ratio }\end{array}$ & $\begin{array}{c}\text { Silica } \\
\left(\mathrm{mgg}^{\mathrm{L}} \mathrm{L} \text { as }\right. \\
\left.\mathrm{SiO}_{2}\right)\end{array}$ & $\begin{array}{c}\text { Iron } \\
(\mu \mathrm{g} / \mathrm{L} \text { as } \mathrm{Fe})\end{array}$ & $\begin{array}{l}\text { Manga- } \\
\text { nese } \\
(\mu \mathrm{g} / \mathrm{L} \text { as } \\
\mathrm{Mn})\end{array}$ & $\begin{array}{c}\text { Arsenic } \\
\text { ( } \mu \mathrm{g} / \mathrm{L} \text { as } \\
\text { As) }\end{array}$ & $\begin{array}{c}\text { Nitrogen } \\
\text { nitrite + } \\
\text { nitrate } \\
\text { (mg/L as N) }\end{array}$ & $\begin{array}{l}\text { Nitrogen, } \\
\text { nitrite } \\
\text { (mg/L as N) }\end{array}$ & $\begin{array}{c}\text { Nitrogen, } \\
\text { ammonia } \\
\text { (mg/L as N) }\end{array}$ & $\begin{array}{c}\text { Phos- } \\
\text { phorus, } \\
\text { ortho- } \\
\text { phosphate } \\
\text { (mg/L as P) }\end{array}$ \\
\hline 1a & 21 & 19 & 0.3 & 0.19 & 100 & 14 & $<10$ & 3.2 & 10.9 & 2.6 & 0.05 & $<0.04$ & $<0.02$ \\
\hline \multirow[t]{5}{*}{$1 b$} & 20 & 10 & 0.2 & - & - & 13 & $<10$ & $<2$ & 9.4 & $<.008$ & $<.02$ & 3.02 & $<.04$ \\
\hline & 13 & 11 & 0.4 & - & - & 12 & E6 & 12 & 3.7 & $<.008$ & $<.02$ & 2.89 & E. .03 \\
\hline & 19 & 17 & 1.1 & - & - & 11 & 11 & 19 & 9.1 & $<.008$ & E.01 & 3.37 & Е.03 \\
\hline & - & - & - & - & - & - & - & - & 4.4 & 2.79 & E. 007 & .06 & $<.02$ \\
\hline & - & - & - & - & - & - & - & - & 9.3 & - & - & - & - \\
\hline \multirow[t]{2}{*}{2} & ${ }^{2} 23$ & ${ }^{2} 22$ & - & ${ }^{2} .05$ & ${ }^{2} 415$ & - & - & - & - & - & - & - & - \\
\hline & 19 & 20 & .2 & .08 & 250 & 15 & $<10$ & E 1 & 10.0 & 2.1 & $<.008$ & $<.04$ & $<.02$ \\
\hline 3 & 19.7 & 17.3 & .2 & .10 & 173 & 12 & E 7 & 11 & 4.2 & 3.15 & $<.008$ & $<.04$ & $<.02$ \\
\hline 3 & 19.7 & 17.8 & .2 & - & - & 11 & 10 & 12 & 2.6 & 3.41 & .008 & .10 & $<.02$ \\
\hline 3 & 16.2 & 13.2 & .2 & - & - & 11 & 27 & 6 & 4.6 & 3.73 & E. 004 & $<.04$ & $<.02$ \\
\hline 3 & 18.0 & 14.3 & .2 & .10 & 143 & 12 & 19 & E 3 & 5.9 & 3.84 & $<.008$ & E.03 & $<.02$ \\
\hline 3 & - & - & - & - & - & - & - & - & 6.0 & - & - & - & - \\
\hline \multirow[t]{4}{*}{5} & 25 & 25 & .3 & .08 & 313 & 31 & - & - & - & 1.6 & .007 & $<.04$ & $<.02$ \\
\hline & ${ }^{2} 26$ & ${ }^{2} 26$ & - & ${ }^{2} .16$ & ${ }^{2} 164$ & - & - & - & - & - & - & - & - \\
\hline & - & - & - & - & - & - & - & - & - & - & - & - & - \\
\hline & - & - & - & - & - & - & - & - & - & - & - & - & - \\
\hline \multirow[t]{3}{*}{6} & 58 & 44 & E.1 & .20 & 218 & 13 & $<10$ & $<3$ & 7.1 & 1.5 & $<.006$ & $<.04$ & $<.02$ \\
\hline & 56 & 42 & .2 & .17 & 247 & 13 & $<10$ & $<2$ & 8.0 & E 2.1 & $<.008$ & $<.04$ & $<.02$ \\
\hline & - & - & - & - & - & - & - & - & - & - & - & - & - \\
\hline 7 & ${ }^{2} 42$ & ${ }^{2} 39$ & - & 2.18 & ${ }^{2} 214$ & - & - & - & - & - & - & - & - \\
\hline \multirow[t]{2}{*}{8} & ${ }^{2} 20$ & ${ }^{2} 18$ & - & ${ }^{2} .06$ & ${ }^{2} 306$ & - & - & - & - & - & - & - & - \\
\hline & 18.1 & 18.8 & .2 & .08 & 235 & 14 & $<10$ & $<2$ & 13.2 & 2.35 & $<.008$ & $<.04$ & .02 \\
\hline \multirow[t]{13}{*}{9} & 7.4 & 2.9 & .2 & .01 & 290 & 41 & - & - & - & .5 & .0 & $<.04$ & $<.02$ \\
\hline & ${ }^{2} 12$ & 27 & - & 2.02 & ${ }^{2} 277$ & - & - & - & - & - & - & - & - \\
\hline & 24 & 15 & Е .08 & .16 & 94 & 13 & $<10$ & E 2 & 2.0 & E 1.6 & $<.008$ & $<.04$ & $<.02$ \\
\hline & - & - & - & - & - & - & - & - & - & - & - & - & - \\
\hline & - & - & - & - & - & - & - & - & 2.4 & 1.67 & $<.008$ & $<.04$ & E.009 \\
\hline & - & - & - & - & - & - & - & - & 2.7 & 1.46 & .02 & .09 & $<.02$ \\
\hline & - & - & - & - & - & - & - & - & - & - & - & - & - \\
\hline & - & - & - & - & - & - & - & - & 2.5 & 1.45 & $<.008$ & $<.04$ & $<.02$ \\
\hline & - & 30 & - & .16 & 188 & - & - & - & 2.8 & - & - & - & - \\
\hline & - & - & - & - & - & - & - & - & 2.7 & - & - & - & - \\
\hline & 93 & 90 & .2 & .41 & 220 & 14 & $<6.4$ & E. 05 & 2.8 & - & - & - & - \\
\hline & - & 35.4 & - & - & - & - & - & - & 3.8 & - & - & - & - \\
\hline & - & - & - & - & - & - & - & - & 3.6 & - & - & - & - \\
\hline \multirow[t]{3}{*}{10} & 70 & 39 & .3 & .15 & 258 & 14 & $<10$ & 5 & 16.6 & 1.72 & .03 & .18 & E.01 \\
\hline & - & 28 & - & .14 & 206 & - & - & - & 7.4 & - & - & - & - \\
\hline & - & - & - & - & - & - & - & - & 8.1 & - & - & - & - \\
\hline 11 & ${ }^{2} 33$ & ${ }^{2} 30$ & - & ${ }^{2} .08$ & ${ }^{2} 384$ & - & - & - & - & - & - & - & - \\
\hline 12 & ${ }^{2} 22$ & ${ }^{2} 20$ & - & ${ }^{2} .08$ & ${ }^{2} 255$ & - & - & - & - & - & - & - & - \\
\hline 24 & 22 & 20 & .4 & .19 & 105 & 15 & $<10$ & $<3$ & 33.3 & 2.3 & $<.008$ & $<.04$ & $<.02$ \\
\hline 26 & ${ }^{2} 22$ & ${ }^{2} 21$ & - & ${ }^{2} .09$ & ${ }^{2} 251$ & - & - & - & - & - & - & - & - \\
\hline 27 & ${ }^{2} 28$ & ${ }^{2} 28$ & - & ${ }^{2} .09$ & ${ }^{2} 309$ & - & - & - & - & - & - & - & - \\
\hline \multirow[t]{4}{*}{28} & 1,020 & 744 & .9 & 41.2 & 18 & 13 & $<30$ & $<5$ & 90.1 & 17.8 & $<.008$ & Е.03 & .03 \\
\hline & 584 & 476 & .8 & 2.44 & 195 & 14 & $<30$ & $<5$ & 63.9 & 14.3 & $<.008$ & $<.04$ & .03 \\
\hline & - & - & - & - & - & - & - & - & 51.0 & 3.66 & $<.008$ & $<.04$ & .03 \\
\hline & - & - & - & - & - & - & - & - & 41.9 & 7.20 & $<.008$ & $<.04$ & .02 \\
\hline
\end{tabular}


Table 3. Selected physical properties and major and minor chemical constituents in ground- and surface-water samples collected from selected sites in Sand Hollow and the Virgin River near Virgin, Utah—Continued

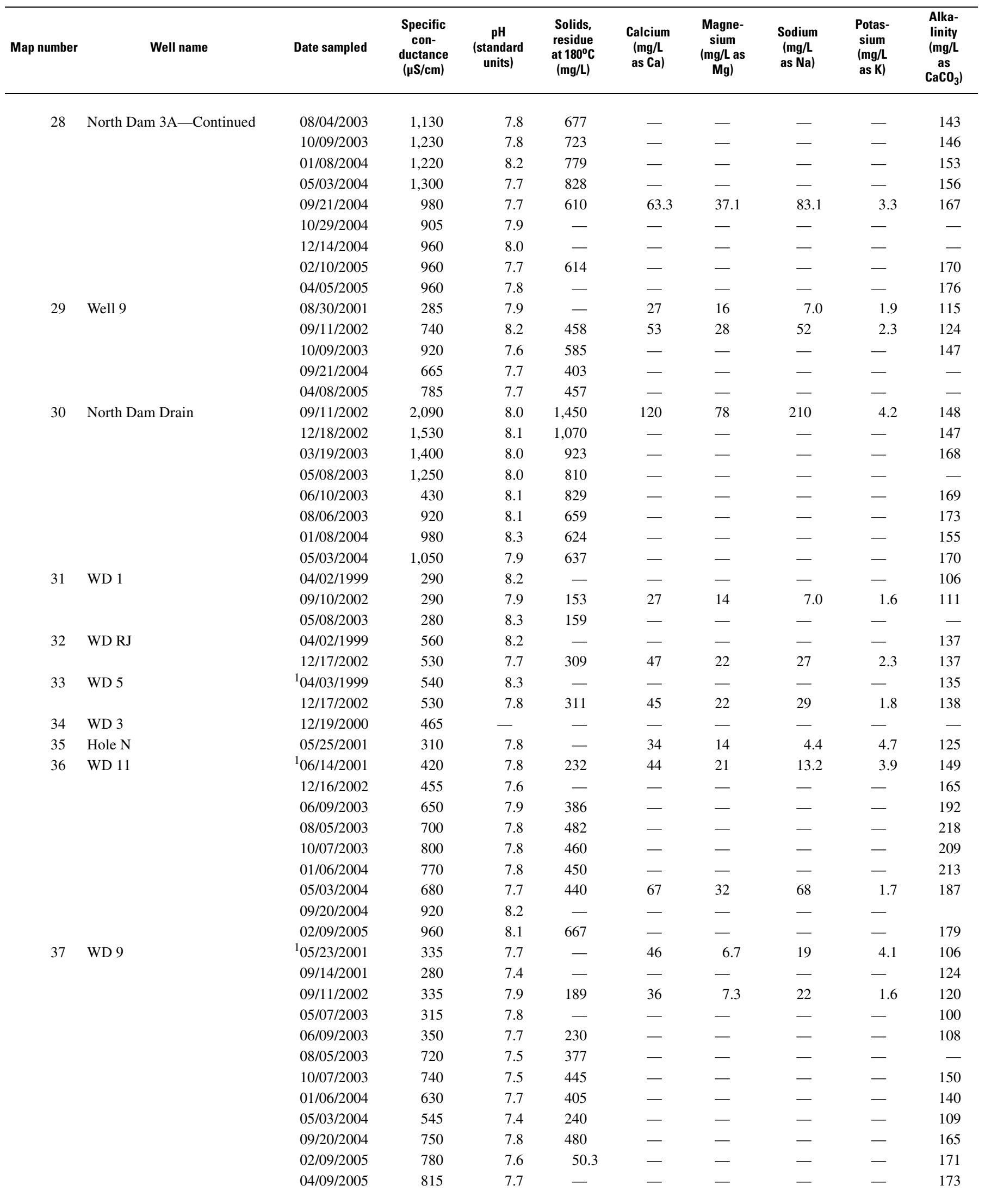


Table 3. Selected physical properties and major and minor chemical constituents in ground-and surface-water samples collected from selected sites in Sand Hollow and the Virgin River near Virgin, Utah—Continued

\begin{tabular}{|c|c|c|c|c|c|c|c|c|c|c|c|c|c|}
\hline Map number & $\begin{array}{c}\text { Sulfate } \\
(\mathrm{mg} / \mathrm{L} \text { as } \\
\left.\mathrm{SO}_{4}\right)\end{array}$ & $\begin{array}{l}\text { Chloride } \\
\text { (mg/L as } \\
\text { Cl) }\end{array}$ & $\begin{array}{l}\text { Fluoride } \\
\text { (mg/L as F) }\end{array}$ & $\begin{array}{c}\text { Bromide } \\
(\mathrm{mg} / \mathrm{L} \text { as } \\
\mathrm{Br})\end{array}$ & $\begin{array}{l}\text { Chloride: } \\
\text { Bromide } \\
\text { ratio }\end{array}$ & $\begin{array}{c}\text { Silica } \\
\left(\mathrm{mg}^{\mathrm{m} / \mathrm{L} \text { as }}\right. \\
\left.\mathrm{SiO}_{2}\right)\end{array}$ & $\begin{array}{c}\text { Iron } \\
(\mu \mathrm{g} / \mathrm{L} \text { as } \mathrm{Fe})\end{array}$ & $\begin{array}{c}\text { Manga- } \\
\text { nese } \\
(\mu \mathrm{gg} / \mathrm{L} \text { as } \\
\mathrm{Mn})\end{array}$ & $\begin{array}{c}\text { Arsenic } \\
\text { ( } \mu \mathrm{g} / \mathrm{L} \text { as } \\
\text { As) }\end{array}$ & $\begin{array}{c}\text { Nitrogen } \\
\text { nitrite + } \\
\text { nitrate } \\
\text { (mg/L as N) }\end{array}$ & $\begin{array}{c}\text { Nitrogen, } \\
\text { nitrite } \\
\text { (mg/L as N) }\end{array}$ & $\begin{array}{c}\text { Nitrogen, } \\
\text { ammonia } \\
\text { (mg/L as N) }\end{array}$ & $\begin{array}{c}\text { Phos- } \\
\text { phorus, } \\
\text { ortho- } \\
\text { phosphate } \\
\text { (mg/L as P) }\end{array}$ \\
\hline \multirow[t]{9}{*}{28} & - & - & - & - & - & - & - & - & 42.1 & 6.42 & $<0.008$ & $<0.04$ & E 0.02 \\
\hline & - & 130 & - & 0.62 & 209 & - & - & - & ${ }^{6} 36.4$ & - & - & - & - \\
\hline & - & - & - & - & - & - & - & - & 46.7 & - & - & - & - \\
\hline & - & - & - & - & - & - & - & - & 45.7 & - & - & - & - \\
\hline & 207 & 73.7 & 0.6 & .11 & 664 & 14 & $<6.4$ & $<0.8$ & 46.4 & - & - & - & - \\
\hline & - & - & - & - & - & - & - & - & 48.0 & - & - & - & - \\
\hline & - & - & - & - & - & - & - & - & 46.5 & - & - & - & - \\
\hline & - & 74.0 & - & - & - & - & - & - & 42.4 & - & - & - & - \\
\hline & - & - & - & - & - & - & - & - & 43.9 & - & - & - & - \\
\hline \multirow[t]{5}{*}{29} & 13 & 13 & .2 & .07 & 186 & 13 & $<10$ & $<3$ & 12.4 & 2.4 & $<.006$ & $<.04$ & $<.02$ \\
\hline & 126 & 72 & .2 & .28 & 258 & 14 & 250 & 6 & 17.0 & E 2.2 & $<.008$ & $<.04$ & $<.02$ \\
\hline & - & 85 & - & .26 & 331 & - & - & - & 12.8 & - & - & - & - \\
\hline & - & - & - & - & - & - & - & - & 14.5 & - & - & - & - \\
\hline & - & - & - & - & - & - & - & - & 16.7 & - & - & - & - \\
\hline \multirow[t]{8}{*}{30} & 560 & 220 & 1.4 & 10 & 22 & 24 & $<10$ & $<2$ & 31.0 & E 12 & Е.004 & $<.04$ & Е.02 \\
\hline & - & - & - & - & - & - & - & - & 40.3 & 2.95 & $<.008$ & $<.04$ & .03 \\
\hline & - & - & - & - & - & - & - & - & 27.9 & 1.88 & $<.008$ & .012 & .016 \\
\hline & - & - & - & - & - & - & - & - & 26.0 & 1.65 & .02 & $<.04$ & E.02 \\
\hline & - & - & - & - & - & - & - & - & 23.8 & 1.41 & $<.008$ & $<.04$ & E.02 \\
\hline & - & - & - & - & - & - & - & - & 25.1 & .76 & $<.008$ & $<.04$ & E.009 \\
\hline & - & - & - & - & - & - & - & - & 28.0 & - & - & - & - \\
\hline & - & - & - & - & - & - & - & - & 19.3 & - & - & - & - \\
\hline \multirow[t]{3}{*}{31} & ${ }^{2} 13$ & ${ }^{2} 12$ & - & ${ }^{2} .04$ & ${ }^{2} 323$ & - & - & - & - & - & - & - & - \\
\hline & 13 & 11 & .2 & .06 & 182 & 14 & $<10$ & $<2$ & 14.4 & E 2.2 & $<.008$ & $<.04$ & $<.02$ \\
\hline & - & - & - & - & - & - & - & - & 15.2 & 2.04 & .02 & $<.04$ & $<.02$ \\
\hline \multirow[t]{2}{*}{32} & ${ }^{2} 53$ & ${ }^{2} 46$ & - & ${ }^{2} .13$ & ${ }^{2} 348$ & - & - & - & - & - & - & - & - \\
\hline & 46.1 & 47.8 & .5 & .20 & 239 & 14 & $<10$ & $<2$ & 7.9 & 3.28 & $<.008$ & $<.04$ & E.01 \\
\hline \multirow[t]{2}{*}{33} & ${ }^{2} 47$ & ${ }^{2} 44$ & - & ${ }^{2} .13$ & ${ }^{2} 348$ & - & - & - & - & - & - & - & - \\
\hline & 46.8 & 44.8 & .3 & .16 & 280 & 13 & $<10$ & E 1 & 9.1 & 4.18 & $<.008$ & $<.04$ & E.01 \\
\hline 34 & 35 & ${ }^{2} 28$ & - & ${ }^{2} .15$ & ${ }^{2} 188$ & - & - & - & - & - & - & - & - \\
\hline 35 & 16 & 6.5 & .7 & .05 & 130 & 18 & 13 & 6 & 18.1 & .67 & .01 & E. 03 & E.02 \\
\hline \multirow[t]{9}{*}{36} & 31 & 14 & .5 & .10 & 140 & 17 & - & - & - & 1.7 & .007 & $<.04$ & $<.02$ \\
\hline & - & - & - & - & - & - & - & - & 7.3 & & & & \\
\hline & - & - & - & - & - & - & - & - & 15.4 & 4.59 & $<.008$ & $<.04$ & Е.01 \\
\hline & - & - & - & - & - & - & - & - & 16.0 & 3.02 & $<.008$ & Е.02 & E.01 \\
\hline & - & 64 & - & .33 & 194 & - & - & - & 16.2 & - & - & - & - \\
\hline & - & - & - & - & - & - & - & - & 17.1 & - & - & - & - \\
\hline & 90 & 50 & .4 & .25 & 199 & 15 & $<6.4$ & $<.8$ & 15.3 & 3.06 & $<.008$ & $<.04$ & .02 \\
\hline & - & - & - & - & - & - & - & - & - & - & - & - & - \\
\hline & - & - & - & - & - & - & - & - & 17.0 & - & - & - & - \\
\hline \multirow[t]{12}{*}{37} & 18 & 22 & .5 & .06 & 367 & 22 & - & - & 9.4 & .29 & .008 & $<.04$ & $<.02$ \\
\hline & ${ }^{2} 15$ & ${ }^{2} 18$ & - & ${ }^{2} .12$ & ${ }^{2} 154$ & - & - & - & - & - & - & - & - \\
\hline & 18 & 21 & .5 & .06 & 350 & 15 & E 9 & 15 & 12.0 & E. 48 & $<.008$ & $<.04$ & E.01 \\
\hline & - & - & - & - & - & - & - & - & & & & & \\
\hline & - & - & - & - & - & - & - & - & 11.8 & .909 & $<.008$ & $<.04$ & E.01 \\
\hline & - & - & - & - & - & - & - & - & 9.8 & .757 & $<.008$ & $<.04$ & E.01 \\
\hline & - & 53 & - & .06 & 883 & - & - & - & 5.8 & - & - & - & - \\
\hline & - & - & - & - & - & - & - & - & 8.6 & - & - & - & - \\
\hline & - & - & - & - & - & - & - & - & 13.3 & - & - & - & - \\
\hline & - & - & - & .04 & - & - & - & - & 6.2 & - & - & - & - \\
\hline & - & 56 & - & - & - & - & - & - & 6.8 & - & - & - & - \\
\hline & - & - & - & - & - & - & - & - & 7.3 & - & - & - & - \\
\hline
\end{tabular}


Table 3. Selected physical properties and major and minor chemical constituents in ground- and surface-water samples collected from selected sites in Sand Hollow and the Virgin River near Virgin, Utah-Continued

\begin{tabular}{|c|c|c|c|c|c|c|c|c|c|c|}
\hline Map number & Well name & Date sampled & $\begin{array}{c}\text { Specific } \\
\text { con- } \\
\text { ductance } \\
(\mu \mathrm{S} / \mathrm{cm})\end{array}$ & $\begin{array}{c}\mathrm{pH} \\
\text { (standard } \\
\text { units) }\end{array}$ & $\begin{array}{l}\text { Solids, } \\
\text { residue } \\
\text { at } 180^{\circ} \mathrm{C} \\
(\mathrm{mg} / \mathrm{L})\end{array}$ & $\begin{array}{l}\text { Calcium } \\
\text { (mg/L } \\
\text { as Ca) }\end{array}$ & $\begin{array}{l}\text { Magne- } \\
\text { sium } \\
(\mathrm{mg} / \mathrm{L} \text { as } \\
\mathrm{Mg})\end{array}$ & $\begin{array}{l}\text { Sodium } \\
(\mathrm{mg} / \mathrm{L} \\
\text { as Na) }\end{array}$ & $\begin{array}{l}\text { Potas- } \\
\text { sium } \\
(\mathrm{mg} / \mathrm{L} \\
\text { as K) }\end{array}$ & $\begin{array}{c}\text { Alka- } \\
\text { linity } \\
\text { (mg/L } \\
\text { as } \\
\left.\mathrm{CaCO}_{3}\right)\end{array}$ \\
\hline \multirow[t]{2}{*}{38} & Basin 1 & ${ }^{1} 07 / 22 / 1999$ & - & - & - & - & - & - & - & - \\
\hline & & 09/10/2001 & 620 & 7.6 & - & 36 & 25 & 43 & 2.4 & 141 \\
\hline \multirow[t]{2}{*}{39} & Slope 1a & ${ }^{1} 04 / 28 / 1999$ & 270 & 8.1 & - & - & - & - & - & 94 \\
\hline & & 03/20/2003 & 265 & 7.8 & - & - & - & - & - & - \\
\hline \multirow[t]{2}{*}{42} & Terracor 3 & 04/23/1999 & 320 & 8.3 & - & - & - & - & - & 124 \\
\hline & & $09 / 11 / 2001$ & 335 & 7.9 & - & 33 & 21 & 19 & 1.6 & 136 \\
\hline \multirow[t]{2}{*}{43} & Hole O & ${ }^{1} 06 / 11 / 2001$ & 465 & 7.6 & - & 39 & 31 & 18 & 11 & 160 \\
\hline & & $09 / 11 / 2001$ & 425 & 8.0 & - & - & - & - & - & 192 \\
\hline 44 & & $10 / 16 / 2003$ & 355 & 7.4 & - & - & - & - & - & 127 \\
\hline \multirow[t]{2}{*}{46} & Basin 2 & ${ }^{1} 07 / 21 / 1999$ & 295 & 8.1 & - & - & - & - & - & - \\
\hline & & $08 / 27 / 2001$ & 290 & 7.8 & - & 30 & 13 & 8.5 & 2.4 & 115 \\
\hline \multirow[t]{2}{*}{47} & WD 13 & 08/30/2001 & 275 & 8.1 & - & 24 & 16 & 8.4 & 1.5 & 109 \\
\hline & & $10 / 16 / 2003$ & 225 & 8.2 & - & - & - & - & - & 86 \\
\hline 48 & Well 17 & 05/18/2000 & 410 & 8.1 & - & - & - & - & - & 117 \\
\hline 49 & WD 14 & $12 / 18 / 2002$ & 385 & 7.7 & 220 & 36 & 20 & 10 & 2.4 & 122 \\
\hline \multirow[t]{3}{*}{50} & WD 7 & 09/10/2001 & 380 & 7.8 & - & 37 & 12 & 25 & 1.9 & 137 \\
\hline & & 05/07/2003 & 390 & 7.9 & - & - & - & - & - & 137 \\
\hline & & $10 / 08 / 2003$ & 395 & 7.8 & 230 & - & - & - & - & 130 \\
\hline${ }^{3} \mathrm{VR}$ & Virgin River & 08/29/2001 & 850 & 8.4 & - & 74 & 29 & 55 & 4.4 & 159 \\
\hline \multirow{3}{*}{${ }^{4}$ RES } & & 05/05/2004 & 710 & 8.2 & 442 & 63 & 26 & 45 & 3.3 & 161 \\
\hline & & $09 / 22 / 2004$ & 765 & 8.5 & - & - & - & - & - & 139 \\
\hline & & $02 / 10 / 2005$ & 855 & 8.4 & 546 & - & - & - & - & 159 \\
\hline${ }^{5} \mathrm{EW}$ & Ephemeral Wash & $11 / 09 / 2002$ & 85 & 8.0 & 49 & 14 & 1 & 0 & 1.3 & 42 \\
\hline
\end{tabular}

${ }^{1}$ Sample collected in open hole prior to well installation.

${ }^{2}$ Analyzed by Los Alamos National Laboratory in Los Alamos, New Mexico.

${ }^{3}$ Surface water measured or sampled at Virgin River near Virgin, Utah.

${ }^{4}$ Surface water measured or sampled in Sand Hollow Reservoir, Utah.

${ }^{5}$ Surface water measured or sampled in ephemeral wash at map number 44.

${ }^{6}$ Analyzed by the USGS Research Laboratory, Boulder, Colorado. 
Table 3. Selected physical properties and major and minor chemical constituents in ground-and surface-water samples collected from selected sites in Sand Hollow and the Virgin River near Virgin, Utah—Continued

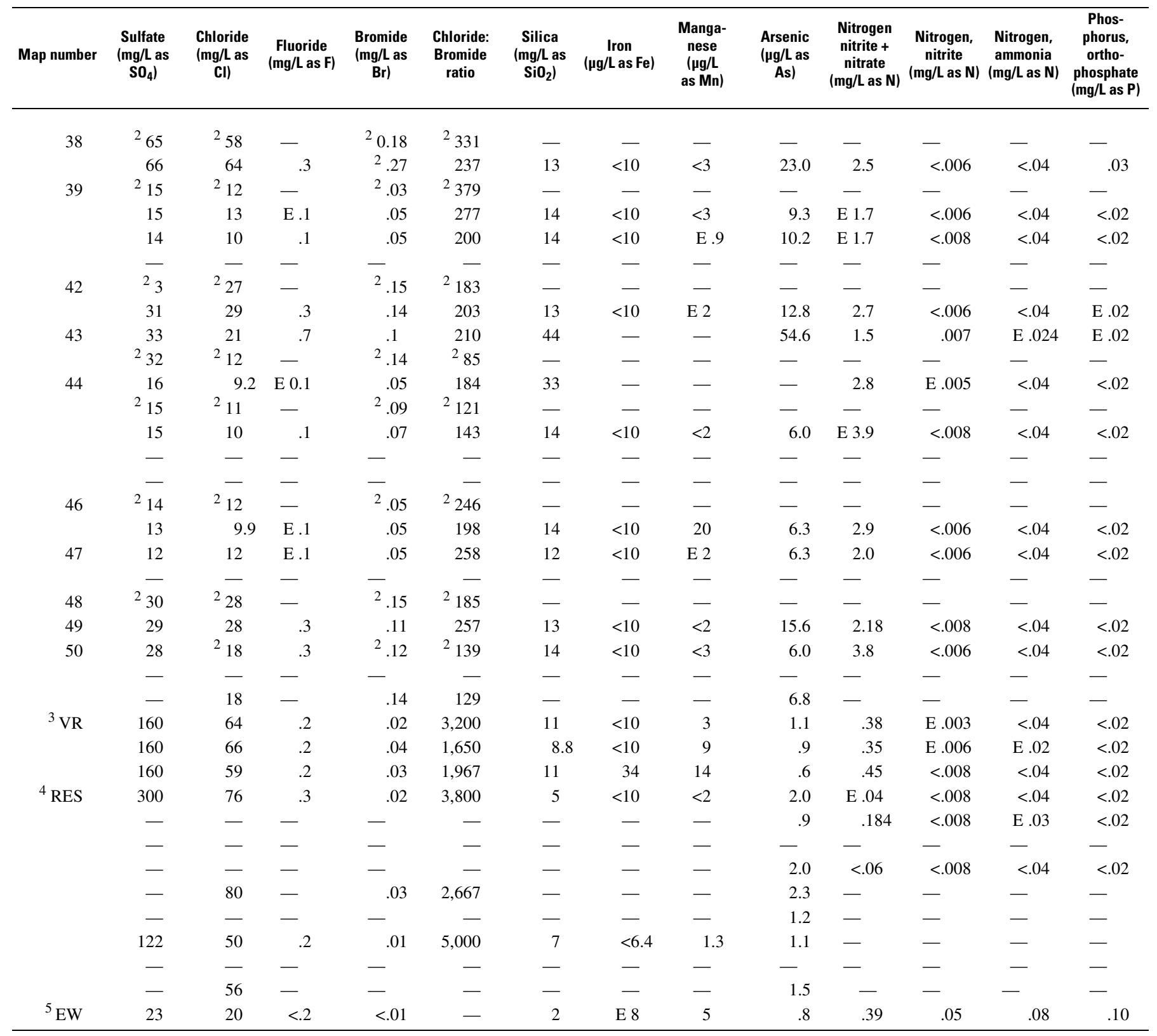


Table 4. Isotopic and chlorofluorocarbon concentrations of ground- and surface-water samples collected in and near Sand Hollow, Utah

[Map number: Refer to figure 3; Stable isotopes: $\delta^{2} \mathrm{H}$ : Hydrogen-2/hydrogen-1 stable isotope ratio, in permil; $\delta^{18} \mathrm{O}$ : Oxygen-18/oxygen-16 stable isotope ratio, in permil; $\delta^{13} \mathrm{C}$ : Carbon-13/carbon-12 stable isotope ratio, in permil; ${ }^{14} \mathrm{C}$ : Carbon-14 concentration in pmc, percent modern carbon; ${ }^{3} \mathrm{H}$ : tritium concentration and precision in $\mathrm{TU}$, tritium units where one tritium unit $=$ one atom of ${ }^{3} \mathrm{H}$ in $10^{18}$ atom of ${ }^{1} \mathrm{H}$; pmol $/ \mathrm{kg}$, picomoles per kilogram; —, no data available ]

\begin{tabular}{|c|c|c|c|c|c|}
\hline \multirow[b]{2}{*}{$\begin{array}{c}\text { Map } \\
\text { number }\end{array}$} & \multirow[b]{2}{*}{ Well name } & \multirow[b]{2}{*}{ Date sampled } & \multicolumn{3}{|c|}{ Stable isotopes } \\
\hline & & & $\begin{array}{c}\delta^{2} \mathrm{H} \\
\text { (permil) }\end{array}$ & $\begin{array}{c}\delta^{18} \mathbf{0} \\
\text { (permil) }\end{array}$ & $\begin{array}{c}\delta^{13} \mathbf{C} \\
\text { (permil) }\end{array}$ \\
\hline $1 \mathrm{a}$ & Wayne Wilson (original) & $01 / 04 / 2000$ & -83 & -11.5 & - \\
\hline \multirow[t]{2}{*}{$1 \mathrm{~b}$} & Wayne Wilson (redrilled) at 200 feet & 05/06/2003 & -93 & -12.2 & -7.4 \\
\hline & Wayne Wilson (redrilled) at 890 feet & $05 / 06 / 2003$ & -93 & -12.1 & -6.6 \\
\hline \multirow[t]{4}{*}{2} & WD 12 (Slope 2) & ${ }^{1} 04 / 30 / 1999$ & -85 & -11.3 & - \\
\hline & & $1,204 / 30 / 1999$ & -83 & -11.0 & - \\
\hline & & $1,204 / 30 / 1999$ & -86 & - & - \\
\hline & & $09 / 12 / 2002$ & -85 & -10.8 & -7.7 \\
\hline \multirow[t]{5}{*}{3} & Well 2 (east side) at 245 feet & $10 / 09 / 2002$ & -89 & -11.7 & -7.3 \\
\hline & Well 2 (east side) at 400 feet & $10 / 10 / 2002$ & -89 & -11.5 & -7.1 \\
\hline & Well 2 (east side) at 500 feet & $10 / 10 / 2002$ & -92 & -11.7 & - \\
\hline & Well 2 (east side) at 615 feet & $10 / 10 / 2002$ & -92 & -11.8 & -7.6 \\
\hline & Well 2 (east side) at 750 feet & $10 / 10 / 2002$ & -94 & -11.9 & -7.0 \\
\hline \multirow[t]{3}{*}{5} & WD 10 (Island) & ${ }^{1} 06 / 12 / 2001$ & -85 & -11.0 & - \\
\hline & & $1,206 / 12 / 2001$ & -84 & -11.1 & - \\
\hline & & 09/13/2001 & -85 & -11.2 & -7.2 \\
\hline \multirow[t]{4}{*}{6} & Well 4 (Sky Ranch 2) & 03/30/1999 & -84 & -11.6 & - \\
\hline & & $08 / 29 / 2001$ & -85 & -11.1 & - \\
\hline & & $02 / 14 / 2002$ & - & - & - \\
\hline & & $09 / 11 / 2002$ & -86 & -11.0 & -7.0 \\
\hline \multirow[t]{2}{*}{7} & Dale Wilson & 04/28/1999 & -84 & -10.2 & - \\
\hline & & ${ }^{2} 04 / 28 / 1999$ & -83 & - & - \\
\hline \multirow[t]{2}{*}{8} & WD 4 & 04/02/1999 & -86 & -11.0 & - \\
\hline & & $12 / 18 / 2002$ & -85 & -10.8 & -6.3 \\
\hline \multirow[t]{3}{*}{9} & WD 6 (Slickrock) & $05 / 15 / 2001$ & -82 & -10.7 & - \\
\hline & & $08 / 28 / 2001$ & -79 & -10.5 & - \\
\hline & & 09/09/2002 & -82 & -10.4 & - \\
\hline 10 & Well 8 (west side North Dam) & $10 / 08 / 2002$ & -82 & -10.8 & - \\
\hline 11 & WD 2 & 04/02/1999 & -90 & -11.3 & - \\
\hline \multirow[t]{3}{*}{12} & IFP 1 & ${ }^{1} 04 / 20 / 1999$ & -86 & -11.0 & - \\
\hline & & $1,204 / 20 / 1999$ & -82 & -11.1 & - \\
\hline & & $1,204 / 20 / 1999$ & -84 & - & - \\
\hline 13 & IFP 1 (Port 1$)$ & $05 / 18 / 2000$ & - & - & - \\
\hline 16 & IFP 1 (Port 4) & $05 / 18 / 2000$ & - & - & - \\
\hline 17 & IFP 1 (Port 5) & $05 / 17 / 2000$ & - & - & - \\
\hline \multirow[t]{3}{*}{18} & IFP 5 Shallow & $05 / 17 / 2000$ & -87 & -10.5 & - \\
\hline & & ${ }^{2} 05 / 17 / 2000$ & -84 & -10.7 & - \\
\hline & & ${ }^{2} 05 / 17 / 2000$ & -85 & -10.7 & - \\
\hline 19 & IFP 5 Medium & $05 / 17 / 2000$ & -85 & -11.0 & - \\
\hline 20 & IFP 5 Deep & $05 / 17 / 2000$ & -86 & -11.0 & - \\
\hline \multirow[t]{2}{*}{26} & IFP 2 & $04 / 21 / 1999$ & -84 & -11.6 & - \\
\hline & & ${ }^{2} 04 / 21 / 1999$ & -85 & - & - \\
\hline \multirow[t]{2}{*}{27} & Wash 1 & 04/20/1999 & -86 & -11.2 & - \\
\hline & & ${ }^{2} 04 / 20 / 1999$ & -85 & - & - \\
\hline 28 & North Dam $3 \mathrm{~A}^{3}$ & $10 / 08 / 2002$ & -83 & -10.4 & - \\
\hline
\end{tabular}


Table 4. Isotopic and chlorofluorocarbon concentrations of ground- and surface-water samples collected in and near Sand Hollow, Utah-Continued

\begin{tabular}{|c|c|c|c|c|c|c|}
\hline \multirow[b]{2}{*}{$\begin{array}{c}\text { Map } \\
\text { number }\end{array}$} & \multicolumn{2}{|c|}{${ }^{14} \mathrm{C}$} & \multicolumn{2}{|c|}{${ }^{3} \mathrm{H}$} & \multicolumn{2}{|c|}{ Chlorofluorocarbons } \\
\hline & $\begin{array}{c}\text { Concentration } \\
(\mathrm{pmc})\end{array}$ & $\begin{array}{c}\text { Precision, +/- } \\
(\text { pmc) }\end{array}$ & $\begin{array}{c}\text { Concentration } \\
\text { (TU) }\end{array}$ & $\begin{array}{l}\text { Precision, +/- } \\
\text { (TU) }\end{array}$ & $\begin{array}{c}\text { Average CFC-11 } \\
(\mathrm{pmol} / \mathrm{kg})\end{array}$ & $\begin{array}{l}\text { Average CFC-12 } \\
\text { (pmol/kg) }\end{array}$ \\
\hline $1 \mathrm{a}$ & - & - & 0.03 & 0.05 & - & - \\
\hline \multirow[t]{2}{*}{$1 \mathrm{~b}$} & 17.9 & .20 & .34 & .02 & - & - \\
\hline & 16.7 & .19 & .40 & .02 & - & - \\
\hline \multirow[t]{4}{*}{2} & - & - & .53 & .38 & - & - \\
\hline & - & - & - & - & - & - \\
\hline & - & - & - & - & - & - \\
\hline & 61.3 & .34 & .02 & .06 & - & - \\
\hline \multirow[t]{5}{*}{3} & 22.6 & .27 & .33 & .02 & - & - \\
\hline & 23.1 & .28 & .55 & .22 & - & - \\
\hline & - & - & - & - & - & - \\
\hline & 15.1 & .22 & .02 & .02 & - & - \\
\hline & 14.7 & .30 & .22 & .06 & - & - \\
\hline \multirow[t]{3}{*}{5} & - & - & .45 & .25 & - & - \\
\hline & - & - & - & - & - & - \\
\hline & 62.7 & .46 & .73 & .35 & 2.51 & 1.62 \\
\hline \multirow[t]{4}{*}{6} & - & - & .52 & .36 & - & - \\
\hline & - & - & .26 & .21 & - & - \\
\hline & - & - & - & - & .38 & .24 \\
\hline & 57.4 & .33 & - & - & - & - \\
\hline \multirow[t]{2}{*}{7} & - & - & .40 & .26 & - & - \\
\hline & - & - & - & - & - & - \\
\hline \multirow[t]{2}{*}{8} & - & - & .22 & .10 & - & - \\
\hline & 70.7 & .51 & - & - & - & - \\
\hline \multirow[t]{3}{*}{9} & - & - & 4.77 & .24 & - & - \\
\hline & - & - & 6.88 & .34 & - & - \\
\hline & - & - & - & - & - & - \\
\hline 10 & - & - & - & - & - & - \\
\hline 11 & - & - & .38 & .45 & - & - \\
\hline \multirow[t]{3}{*}{12} & - & - & .00 & .66 & - & - \\
\hline & - & - & - & - & - & - \\
\hline & - & - & - & - & - & - \\
\hline 13 & - & - & .12 & .05 & - & - \\
\hline 16 & - & - & .03 & .03 & - & - \\
\hline 17 & - & - & .00 & .01 & - & - \\
\hline \multirow[t]{3}{*}{18} & - & - & .08 & .08 & - & - \\
\hline & - & - & - & - & - & - \\
\hline & - & - & - & - & - & - \\
\hline 19 & - & - & .18 & .14 & - & - \\
\hline 20 & - & - & .08 & .05 & - & - \\
\hline \multirow[t]{2}{*}{26} & - & - & - & - & - & - \\
\hline & - & - & - & - & - & - \\
\hline \multirow[t]{2}{*}{27} & - & - & .27 & .10 & - & - \\
\hline & - & - & - & - & - & - \\
\hline 28 & - & - & - & - & - & - \\
\hline
\end{tabular}


Table 4. Isotopic and chlorofluorocarbon concentrations of ground- and surface-water samples collected in and near Sand Hollow, Utah-Continued

\begin{tabular}{|c|c|c|c|c|c|}
\hline \multirow[b]{2}{*}{$\begin{array}{c}\text { Map } \\
\text { number }\end{array}$} & \multirow[b]{2}{*}{ Well name } & \multirow[b]{2}{*}{ Date sampled } & \multicolumn{3}{|c|}{ Stable isotopes } \\
\hline & & & $\begin{array}{c}\delta^{2} \mathrm{H} \\
\text { (permil) }\end{array}$ & $\begin{array}{c}\delta^{18} 0 \\
\text { (permil) }\end{array}$ & $\begin{array}{c}\delta^{13} \mathrm{C} \\
\text { (permil) }\end{array}$ \\
\hline \multirow[t]{2}{*}{29} & Well 9 (east side of North Dam) & 08/30/2001 & -86 & -11.4 & -7.2 \\
\hline & & $09 / 11 / 2002$ & -87 & -10.6 & - \\
\hline 30 & North Dam Drain ${ }^{3}$ & $10 / 08 / 2002$ & -80 & -9.6 & - \\
\hline \multirow[t]{3}{*}{31} & WD 1 & 04/02/1999 & -83 & -10.6 & - \\
\hline & & ${ }^{2} 04 / 02 / 1999$ & -84 & - & - \\
\hline & & $09 / 10 / 2002$ & -85 & -10.9 & -7.4 \\
\hline \multirow[t]{2}{*}{32} & WD RJ & 04/02/1999 & -83 & -10.7 & - \\
\hline & & $12 / 17 / 2002$ & -84 & -10.3 & -5.8 \\
\hline \multirow[t]{2}{*}{33} & WD 5 & 04/03/1999 & -85 & -11.2 & - \\
\hline & & $12 / 17 / 2002$ & -85 & -10.6 & -6.7 \\
\hline 34 & WD 3 & $12 / 19 / 2000$ & -89 & -10.6 & - \\
\hline 35 & Hole N & $05 / 25 / 2001$ & -82 & -10.6 & - \\
\hline \multirow[t]{3}{*}{36} & WD 11 (West Dam) & ${ }^{1} 06 / 14 / 2001$ & -85 & -9.7 & - \\
\hline & & $09 / 14 / 2001$ & -86 & -10.8 & -8.0 \\
\hline & & $12 / 16 / 2002$ & - & - & -8.0 \\
\hline \multirow[t]{3}{*}{37} & WD 9 (Boat Ramp) & ${ }^{1} 05 / 23 / 2001$ & -88 & -11.5 & - \\
\hline & & $09 / 14 / 2001$ & -86 & -11.4 & -8.0 \\
\hline & & $09 / 11 / 2002$ & -89 & -11.5 & - \\
\hline \multirow[t]{2}{*}{38} & Basin 1 & ${ }^{1} 07 / 22 / 1999$ & -88 & -10.9 & - \\
\hline & & 09/10/2001 & -84 & -10.7 & -6.5 \\
\hline \multirow[t]{5}{*}{39} & Slope 1a & $104 / 28 / 1999$ & -85 & - & - \\
\hline & & 07/20/1999 & -85 & -11.1 & - \\
\hline & & ${ }^{2} 07 / 20 / 1999$ & -87 & -11.1 & - \\
\hline & & $09 / 12 / 2001$ & -83 & -11.4 & -7.3 \\
\hline & & 09/09/2002 & -86 & -11.4 & - \\
\hline \multirow[t]{3}{*}{42} & Terracor 3 & $04 / 23 / 1999$ & -82 & -10.9 & - \\
\hline & & ${ }^{2} 04 / 23 / 1999$ & -82 & - & - \\
\hline & & $09 / 11 / 2001$ & -85 & -11.0 & - \\
\hline \multirow[t]{2}{*}{43} & Hole O & ${ }^{1} 06 / 11 / 2001$ & -84 & -10.1 & - \\
\hline & & $09 / 11 / 2001$ & -85 & -10.3 & -9.5 \\
\hline \multirow[t]{4}{*}{44} & WD 8 (Sand Dune) & ${ }^{1} 05 / 21 / 2001$ & -81 & -10.6 & - \\
\hline & & $1,205 / 21 / 2001$ & -81 & -10.6 & - \\
\hline & & $09 / 12 / 2001$ & -86 & -10.9 & -8.5 \\
\hline & & 09/09/2002 & -85 & -10.9 & - \\
\hline \multirow[t]{4}{*}{46} & Basin 2 & ${ }^{1} 05 / 05 / 1999$ & -87 & - & - \\
\hline & & $07 / 21 / 1999$ & -86 & -11.6 & - \\
\hline & & ${ }^{2} 07 / 21 / 1999$ & -86 & -11.7 & - \\
\hline & & $08 / 27 / 2001$ & -88 & -11.1 & -6.9 \\
\hline \multirow[t]{3}{*}{47} & WD 13 (Corral) & $01 / 05 / 2000$ & -86 & -11.6 & - \\
\hline & & 08/30/2001 & -86 & -11.4 & - \\
\hline & & $09 / 14 / 2001$ & - & - & - \\
\hline 48 & Well 17 (West Dam) & $05 / 18 / 2000$ & -87 & -11.2 & - \\
\hline 49 & WD 14 (Terracor 2) & $12 / 18 / 2002$ & -88 & -11.4 & - \\
\hline 50 & WD 7 (south end of West Dam) & 09/10/2001 & -85 & -10.6 & -7.7 \\
\hline \multirow[t]{2}{*}{$\mathrm{VR}^{4}$} & Virgin River & $08 / 29 / 2001$ & -95 & -12.5 & - \\
\hline & & $10 / 03 / 2001$ & -97 & -13.0 & - \\
\hline RES & Sand Hollow Reservoir & $09 / 10 / 2002$ & -91 & -6.2 & - \\
\hline EW & Ephemeral Wash at Map Number 44 & $11 / 09 / 2002$ & -48 & -6.6 & - \\
\hline
\end{tabular}

${ }^{1}$ Collected prior to well installation.

${ }^{2}$ Replicate sample.

${ }^{3}$ Affected by reservoir seepage.

${ }^{4}$ Not shown in figure 3 . 
Table 4. Isotopic and chlorofluorocarbon concentrations of ground- and surface-water samples collected in and near Sand Hollow, Utah-Continued

\begin{tabular}{|c|c|c|c|c|c|c|}
\hline \multirow{2}{*}{$\begin{array}{c}\text { Map } \\
\text { number }\end{array}$} & \multicolumn{2}{|c|}{${ }^{14} \mathrm{C}$} & \multicolumn{2}{|c|}{${ }^{3} \mathrm{H}$} & \multicolumn{2}{|c|}{ Chlorofluorocarbons } \\
\hline & $\begin{array}{c}\text { Concentration } \\
\text { (pmc) }\end{array}$ & $\begin{array}{l}\text { Precision, }+/- \\
\quad(\text { pmc) }\end{array}$ & $\begin{array}{l}\text { Concentration } \\
\text { (TU) }\end{array}$ & $\begin{array}{l}\text { Precision, }+/- \\
\text { (TU) }\end{array}$ & $\begin{array}{l}\text { Average CFC-11 } \\
(\mathrm{pmol} / \mathrm{kg})\end{array}$ & $\begin{array}{c}\text { Average CFC-12 } \\
(\mathrm{pmol} / \mathrm{kg})\end{array}$ \\
\hline \multirow[t]{2}{*}{29} & 39.4 & .32 & 0.10 & 0.04 & .34 & .15 \\
\hline & - & - & - & - & - & - \\
\hline 30 & - & - & - & - & - & - \\
\hline \multirow[t]{3}{*}{31} & - & - & .37 & .50 & - & - \\
\hline & - & - & - & - & - & - \\
\hline & 61.1 & .36 & - & - & - & - \\
\hline \multirow[t]{2}{*}{32} & - & - & .02 & .05 & - & - \\
\hline & 56.9 & .42 & - & - & - & - \\
\hline \multirow[t]{2}{*}{33} & - & - & .19 & .06 & - & - \\
\hline & 57.8 & .44 & - & - & - & - \\
\hline 34 & - & - & .28 & .20 & - & - \\
\hline 35 & - & - & 4.27 & .21 & - & - \\
\hline \multirow[t]{3}{*}{36} & - & - & 1.19 & .77 & - & - \\
\hline & 91.9 & .61 & .53 & .08 & .53 & .24 \\
\hline & 86.9 & .58 & - & - & - & - \\
\hline \multirow[t]{3}{*}{37} & - & - & .00 & .01 & - & - \\
\hline & 70.3 & .50 & .20 & .15 & 2.34 & 2.12 \\
\hline & - & - & - & - & - & - \\
\hline \multirow[t]{2}{*}{38} & - & - & .07 & .21 & - & - \\
\hline & 74.3 & .45 & .18 & .21 & .29 & .16 \\
\hline \multirow[t]{5}{*}{39} & - & - & - & - & - & - \\
\hline & - & - & .39 & .18 & - & - \\
\hline & - & - & - & - & - & - \\
\hline & 66.5 & .47 & .44 & .36 & .57 & .19 \\
\hline & - & - & .07 & .06 & - & - \\
\hline \multirow[t]{3}{*}{42} & - & - & .53 & .09 & - & - \\
\hline & - & - & - & - & - & - \\
\hline & - & - & .28 & .08 & .45 & contaminated \\
\hline \multirow[t]{2}{*}{43} & - & - & 1.03 & .07 & - & - \\
\hline & 105.3 & .57 & 1.09 & .20 & 2.20 & 1.56 \\
\hline \multirow[t]{4}{*}{44} & - & - & 4.13 & .38 & - & - \\
\hline & - & - & - & - & - & - \\
\hline & 66.8 & .44 & 2.98 & .15 & .52 & .37 \\
\hline & - & - & 3.89 & .19 & - & - \\
\hline \multirow[t]{4}{*}{46} & - & - & - & - & - & - \\
\hline & - & - & .23 & .35 & - & - \\
\hline & - & - & - & - & - & - \\
\hline & 73.2 & .51 & .18 & .06 & .55 & .25 \\
\hline \multirow[t]{3}{*}{47} & - & - & .43 & .36 & - & - \\
\hline & - & - & .29 & .15 & - & - \\
\hline & - & - & - & - & .26 & .18 \\
\hline 48 & - & - & - & - & - & - \\
\hline 49 & - & - & .32 & .04 & - & - \\
\hline 50 & 66.4 & .44 & .21 & .09 & 1.39 & .46 \\
\hline \multirow[t]{2}{*}{$\mathrm{VR}^{4}$} & - & - & 1.56 & .09 & - & - \\
\hline & - & - & - & - & - & - \\
\hline RES & - & - & 2.47 & .12 & - & - \\
\hline EW & - & - & 2.28 & .11 & - & - \\
\hline
\end{tabular}


Table 5. Age and apparent recharge year of ground water in Sand Hollow, Utah

[Map number: Refer to figure 3;-, no data available; E, estimated]

\begin{tabular}{|c|c|c|c|c|c|c|c|c|}
\hline \multirow[b]{2}{*}{$\begin{array}{c}\text { Map } \\
\text { number }\end{array}$} & \multirow[b]{2}{*}{ Well name } & \multirow[b]{2}{*}{ Date sampled } & \multirow[b]{2}{*}{$\begin{array}{c}\text { Depth of } \\
\text { openings below } \\
\text { water table } \\
\text { (feet) }\end{array}$} & \multirow[b]{2}{*}{$\begin{array}{c}\text { Apparent } \\
\text { tritium/helium } \\
\text { recharge year }\end{array}$} & \multicolumn{2}{|c|}{ Chlorofluorocarbons } & \multicolumn{2}{|c|}{${ }^{14}$ Carbon } \\
\hline & & & & & $\begin{array}{c}\text { Apparent } \\
\text { CFC-11 } \\
\text { recharge } \\
\text { year }\end{array}$ & $\begin{array}{l}\text { Apparent } \\
\text { CFC-12 } \\
\text { recharge } \\
\text { year }\end{array}$ & $\begin{array}{c}\text { Percent } \\
\text { modern } \\
\text { carbon } \\
(\text { pmc) }\end{array}$ & $\begin{array}{c}\text { Apparent } \\
\text { C-14 age } \\
\text { (years) }\end{array}$ \\
\hline \multirow[t]{2}{*}{$1 \mathrm{~b}$} & Wayne Wilson at 200 feet & 05/06/2003 & $52-272$ & pre-1950s & - & - & 18 & 7,000 \\
\hline & Wayne Wilson at 890 feet & 05/06/2003 & $792-932$ & pre-1950s & - & - & 17 & 7,000 \\
\hline 2 & WD 12 (Slope 2) & $09 / 12 / 2002$ & $1.5-6.5$ & - & - & - & 61 & modern \\
\hline \multirow[t]{4}{*}{3} & Well 2 (east side) at 245 feet & $10 / 08 / 2002$ & $0-81$ & pre-1950s & - & - & 23 & 5,000 \\
\hline & Well 2 (east side) at 400 feet & $10 / 10 / 2002$ & $123-194$ & pre-1950s & - & - & 23 & 5,000 \\
\hline & Well 2 (east side) at 615 feet & $10 / 10 / 2002$ & $363-443$ & pre-1950s & - & - & 15 & 8,500 \\
\hline & Well 2 (east side) at 750 feet & $10 / 10 / 2002$ & $483-643$ & pre-1950s & - & - & 15 & 8,000 \\
\hline \multirow[t]{2}{*}{5} & WD 10 (Island) & $09 / 13 / 2001$ & $0-2.7$ & - & 1983 & 1992 & 63 & modern \\
\hline & & $09 / 12 / 2002$ & & pre-1950s & - & - & - & - \\
\hline \multirow[t]{4}{*}{6} & Well 4 (Sky Ranch 2) & $10 / 03 / 2001$ & $0-459$ & - & - & - & - & - \\
\hline & & $02 / 14 / 2002$ & & pre-1950s & 1966 & 1965 & - & - \\
\hline & & $09 / 11 / 2002$ & & - & - & - & 57 & modern \\
\hline & & $12 / 17 / 2002$ & & pre-1950s & - & - & - & - \\
\hline 8 & WD 4 & $12 / 18 / 2002$ & $20-30$ & pre-1950s & - & - & 71 & modern \\
\hline \multirow[t]{2}{*}{9} & WD 6 (Slickrock) & $08 / 28 / 2001$ & $0-5$ & 1998 & - & - & - & - \\
\hline & & $09 / 12 / 2002$ & & 2000 & - & - & - & - \\
\hline 29 & Well 9 (east side of North Dam) & $08 / 30 / 2001$ & $35-1,071$ & pre-1950s & 1964 & 1963 & 39 & 500 \\
\hline \multirow[t]{2}{*}{31} & WD 1 & $09 / 10 / 2002$ & $7-17$ & - & - & - & 61 & modern \\
\hline & & $12 / 18 / 2002$ & & pre-1950s & - & - & - & - \\
\hline 32 & WD RJ & $12 / 17 / 2002$ & $139-149$ & pre-1950s & - & - & 57 & modern \\
\hline 33 & WD 5 & $12 / 17 / 2002$ & $79-89$ & pre-1950s & - & - & 58 & modern \\
\hline \multirow[t]{3}{*}{36} & WD 11 (West Dam) & $09 / 14 / 2001$ & $16-21$ & - & 1967 & 1966 & 92 & modern \\
\hline & & $09 / 12 / 2002$ & & pre-1950s & - & - & - & - \\
\hline & & $12 / 16 / 2002$ & & - & - & - & 87 & modern \\
\hline \multirow[t]{2}{*}{37} & WD 9 (Boat Ramp) & $09 / 14 / 2001$ & $8-13$ & pre-1950s & 1982 & 1997 & 70 & modern \\
\hline & & $09 / 12 / 2002$ & & pre-1950s & - & - & - & - \\
\hline 38 & Basin 1 & 09/10/2001 & $36-41$ & pre-1950s & 1964 & 1963 & 74 & modern \\
\hline \multirow[t]{2}{*}{39} & Slope 1a & $09 / 12 / 2001$ & $32-37$ & - & 1968 & 1964 & 67 & modern \\
\hline & & $09 / 11 / 2002$ & & pre-1950s & - & - & - & - \\
\hline 42 & Terracor 3 & $09 / 11 / 2001$ & $0-653$ & pre-1950s & 1966 & - & - & - \\
\hline 43 & Hole $\mathrm{O}$ & $09 / 11 / 2001$ & $.5-5.5$ & 1975 & 1979 & 1988 & 105 & modern \\
\hline \multirow[t]{2}{*}{44} & WD 8 (Sand Dune) & $09 / 12 / 2001$ & $6.4-11.4$ & - & 1968 & 1969 & 67 & modern \\
\hline & & 09/10/2002 & & 1997 & - & - & - & - \\
\hline 46 & Basin 2 & $08 / 27 / 2001$ & $20-25$ & pre-1950s & 1968 & 1967 & 73 & modern \\
\hline \multirow[t]{2}{*}{47} & WD 13 (Corral Well) & $09 / 14 / 2001$ & $0-120 \mathrm{E}$ & pre-1950s & 1963 & 1963 & - & - \\
\hline & & $09 / 12 / 2002$ & & pre-1950s & - & - & - & - \\
\hline 49 & WD 14 (Terracor 2) & $12 / 18 / 2002$ & $0-563$ & pre-1950s & - & - & - & - \\
\hline \multirow[t]{2}{*}{50} & WD 7 (south end of West Dam) & 09/10/2001 & 4.8-9.8 & pre-1950s & 1974 & 1971 & 66 & modern \\
\hline & & $09 / 12 / 2002$ & & pre-1950s & - & - & - & - \\
\hline
\end{tabular}


Table 6. Average monthly and annual pan evaporation rates from St. George, Utah, and calculated evaporation rates with Jensen-Haise and turbulent-transfer methods using climate data collected at Sand Hollow, Utah, and calculated Penman evaporation rates using St. George climate data

[—, no data available; E, estimated from 2004 data]

\begin{tabular}{|c|c|c|c|c|c|c|c|c|c|c|c|c|c|}
\hline \multirow{2}{*}{$\begin{array}{l}\text { Method for } \\
\text { estimating } \\
\text { evaporation }\end{array}$} & \multicolumn{12}{|c|}{ Monthly evaporation (inches) } & \multirow{2}{*}{$\begin{array}{c}\text { Total annua } \\
\text { evaporation } \\
\text { (inches) }\end{array}$} \\
\hline & Jan & Feb & Mar & April & May & June & July & Aug & Sept & Oct & Nov & Dec & \\
\hline $\begin{array}{l}\text { Average Monthly Pan } \\
\text { Evaporation, 1869-1993 }\end{array}$ & - & - & 4.57 & 7.36 & 10.08 & 12.22 & 13.17 & 11.55 & 8.22 & 4.83 & 2.68 & - & 74.68 \\
\hline $\begin{array}{l}\text { Corrected ( } 80 \text { percent) Average } \\
\text { Monthly Pan Evaporation, } \\
\text { 1869-1993 }\end{array}$ & - & - & 3.66 & 5.88 & 8.06 & 9.78 & 10.53 & 9.24 & 6.57 & 3.86 & 2.14 & - & 59.7 \\
\hline Jensen-Haise, 1999 & .9 & 1.4 & 3.3 & 3.2 & 7.4 & 9.7 & 9.0 & 8.2 & 6.1 & 3.8 & 1.6 & .7 & 55.3 \\
\hline Jensen-Haise, 2000 & .8 & 1.2 & 2.9 & 5.8 & 8.8 & 10.4 & 11.1 & 8.3 & 6.5 & 3.1 & 1.0 & .7 & 60.6 \\
\hline Jensen-Haise, 2001 & .7 & 1.2 & 3.1 & 4.7 & 8.7 & 10.6 & 10.6 & 9.2 & 6.7 & 3.7 & 1.5 & .5 & 61.2 \\
\hline Jensen-Haise, 2002 & .7 & 1.5 & 2.9 & 5.5 & 8.1 & 10.9 & 10.8 & 9.7 & 5.6 & 3.1 & 1.3 & .6 & 60.7 \\
\hline Jensen-Haise, 2003 & 1.1 & 1.2 & 2.9 & 4.4 & 7.9 & 10.7 & 11.0 & 9.0 & 6.9 & 4.3 & 1.1 & .7 & 61.2 \\
\hline Jensen-Haise, 2004 & .7 & 0.9 & 4.5 & 5.0 & 8.6 & 10.4 & 11.3 & 9.3 & 4.8 & - & - & - & - \\
\hline Turbulent transfer, 2003 & E 1.5 & 2.0 & 3.3 & 4.9 & 5.8 & 8.7 & 6.5 & 6.2 & 6.9 & 5.5 & 2.4 & 1.1 & 54.8 \\
\hline Turbulent transfer, 2004 & 1.5 & 1.9 & 3.2 & 5.3 & - & - & - & - & - & - & - & - & - \\
\hline Penman, St George, 1999 & 3.90 & 3.97 & 5.82 & 5.16 & 6.87 & 7.38 & 7.57 & 8.26 & 7.62 & 7.26 & 5.28 & 3.78 & 72.87 \\
\hline Penman, St George, 2000 & - & 4.03 & 5.38 & 6.88 & 7.6 & 7.72 & 8.45 & 8.04 & ${ }^{1} 6.66$ & ${ }^{1} 5.09$ & ${ }^{1} 3.29$ & 3.75 & ${ }^{1} 66.89$ \\
\hline Penman, St George, 2001 & 3.46 & 3.57 & ${ }^{1} 5.17$ & 5.83 & 7.78 & - & ${ }^{1} 2.24$ & ${ }^{1} 7.78$ & ${ }^{1} 7.45$ & ${ }^{1} 5.78$ & ${ }^{1} 4.12$ & $1_{2.74}$ & ${ }^{1} 55.92$ \\
\hline Penman, St George, 2002 & 3.25 & 3.98 & 5.1 & 6.01 & - & 7.72 & 8.15 & 8.24 & 6.94 & 5.51 & 4.02 & 3.11 & ${ }^{1} 62.03$ \\
\hline Penman, St George, 2003 & 4.09 & 3.25 & 4.88 & 5.12 & 6.71 & 7.22 & 8.27 & 7.57 & 7.32 & 6.44 & 3.5 & 3.22 & 67.57 \\
\hline Penman, St George, 2004 & - & 3.05 & 5.89 & 5.42 & 6.68 & 7.28 & 7.67 & ${ }^{1} 7.67$ & - & - & - & - & - \\
\hline
\end{tabular}

${ }^{1}$ Data missing for at least one day. 
Table 7. Reservoir data and estimated evaporation and ground-water recharge at Sand Hollow, Utah, 2002-04

\begin{tabular}{|c|c|c|c|c|c|c|c|c|c|c|}
\hline Month & $\begin{array}{l}\text { Reservoir } \\
\text { altitude } \\
\text { (feet) }\end{array}$ & $\begin{array}{c}\text { Total surface- } \\
\text { water inflow } \\
\text { (+) or outflow } \\
(-) \\
\text { (acre-feet) }\end{array}$ & $\begin{array}{l}\text { Reservoir } \\
\text { storage } \\
\text { (acre-feet) }\end{array}$ & $\begin{array}{l}\text { Reservoir } \\
\text { storage } \\
\text { change } \\
\text { (acre-feet) }\end{array}$ & $\begin{array}{l}\text { Reservoir } \\
\text { surface } \\
\text { area } \\
\text { (acres) }\end{array}$ & $\begin{array}{c}{ }^{1} \text { Estimated } \\
\text { evaporation } \\
\text { rate } \\
\text { (inches per } \\
\text { month) }\end{array}$ & $\begin{array}{c}\text { Estimated } \\
\text { evaporation } \\
\text { loss } \\
\text { (acre-feet) }\end{array}$ & $\begin{array}{l}\text { Estimated } \\
\text { recharge rate } \\
\text { (acre-feet) }\end{array}$ & $\begin{array}{l}\text { Estimated } \\
\text { recharge rate } \\
\text { (foot per day) }\end{array}$ & $\begin{array}{l}{ }^{2} \text { Viscosity- } \\
\text { corrected } \\
\text { hydraulic } \\
\text { conductivity } \\
\text { (foot per day) }\end{array}$ \\
\hline March 2002 & $3,001.0$ & 6,620 & 3,090 & 3,060 & 260 & 2.9 & 60 & 3,500 & 0.44 & 0.57 \\
\hline April 2002 & $3,002.5$ & 3,690 & 3,500 & 410 & 280 & 5.5 & 130 & 3,160 & .38 & .43 \\
\hline May 2002 & $3,001.0$ & 2,450 & 3,090 & -410 & 260 & 8.1 & 170 & 2,680 & .34 & .33 \\
\hline June 2002 & $2,998.5$ & 0 & 2,480 & -610 & 230 & 10.9 & 210 & 400 & .06 & .06 \\
\hline July 2002 & $2,996.5$ & 0 & 2,050 & -440 & 210 & 10.8 & 190 & 250 & .04 & .04 \\
\hline August 2002 & $2,994.5$ & 0 & 1,650 & -390 & 180 & 9.7 & 150 & 240 & .04 & .04 \\
\hline September 2002 & $2,993.7$ & 0 & 1,300 & -350 & 140 & 5.6 & 70 & 290 & .07 & .07 \\
\hline October 2002 & $2,994.7$ & 790 & 1,500 & 200 & 160 & 3.1 & 40 & 550 & .12 & .13 \\
\hline November 2002 & $3,005.5$ & 3,590 & 4,220 & 2,720 & 320 & 1.3 & 30 & 830 & .09 & .12 \\
\hline December 2002 & $3,011.7$ & 3,930 & 7,000 & 2,780 & 400 & 0.6 & 20 & 1,130 & .09 & .14 \\
\hline January 2003 & $3,017.3$ & 4,580 & 9,760 & 2,760 & 590 & 1.1 & 50 & 1,770 & .10 & .15 \\
\hline February 2003 & $3,019.0$ & 2,850 & 10,670 & 920 & 570 & 1.2 & 60 & 1,870 & .12 & .17 \\
\hline March 2003 & $3,019.5$ & 1,930 & 10,930 & 250 & 580 & 2.9 & 140 & 1,540 & .09 & .11 \\
\hline April 2003 & $3,019.0$ & 540 & 10,680 & -250 & 570 & 4.4 & 210 & 580 & .03 & .04 \\
\hline May 2003 & $3,017.6$ & 0 & 9,930 & -750 & 540 & 7.9 & 350 & 400 & .02 & .02 \\
\hline June 2003 & $3,010.3$ & $-3,120$ & 6,040 & $-3,880$ & 390 & 10.7 & 350 & 420 & .04 & .03 \\
\hline July 2003 & $3,001.8$ & $-2,020$ & 3,200 & $-2,840$ & 240 & 11.0 & 220 & 610 & .08 & .08 \\
\hline August 2003 & $2,998.8$ & 0 & 2,540 & -660 & 230 & 9.0 & 170 & 490 & .07 & .06 \\
\hline September 2003 & $2,997.4$ & 0 & 2,100 & -440 & 220 & 6.9 & 130 & 310 & .05 & .05 \\
\hline October 2003 & $2,996.4$ & 0 & 1,850 & -250 & 170 & 4.3 & 60 & 190 & .04 & .04 \\
\hline November 2003 & $2,994.0$ & 0 & 1,560 & -290 & 200 & 1.1 & 20 & 270 & .04 & .06 \\
\hline December 2003 & $3,006.5$ & 3,590 & 4,700 & 3,140 & 330 & .7 & 20 & 430 & .04 & .06 \\
\hline January 2004 & $3,013.0$ & 3,990 & 7,600 & 2,900 & 480 & .7 & 30 & 1,060 & .07 & .11 \\
\hline February 2004 & $3,016.0$ & 2,320 & 8,840 & 1,240 & 600 & .9 & 50 & 1,030 & .06 & .09 \\
\hline March 2004 & $3,018.5$ & 2,400 & 10,400 & 1,560 & 630 & 4.5 & 240 & 610 & .03 & .04 \\
\hline April 2004 & $3,025.3$ & 5,620 & 15,070 & 4,670 & 750 & 5.0 & 310 & 640 & .03 & .03 \\
\hline May 2004 & $3,026.2$ & 2,050 & 15,830 & 770 & 780 & 8.6 & 560 & 720 & .03 & .03 \\
\hline June 2004 & $3,025.3$ & 0 & 14,400 & $-1,430$ & 750 & 10.4 & 650 & 780 & .03 & .03 \\
\hline July 2004 & $3,023.0$ & 0 & 13,000 & $-1,400$ & 680 & 11.3 & 640 & 760 & .04 & .03 \\
\hline August 2004 & $3,020.8$ & 0 & 11,670 & $-1,330$ & 680 & 9.3 & 520 & 810 & .04 & .04 \\
\hline Total or Average & - & ${ }^{3} 45,800$ & - & - & - & $4_{5.5}$ & ${ }^{3} 5,850$ & ${ }^{3} 28,320$ & ${ }^{5} .06$ & ${ }^{5} .07$ \\
\hline
\end{tabular}

${ }^{1}$ Calculated using the Jensen-Haise method.

${ }^{2}$ Assuming a unit hydraulic gradient.

${ }^{3}$ Total.

${ }^{4}$ Average.

${ }^{5}$ Average, excluding initial 3 months. 
